UNIVERSIDADE DE SÃO PAULO

ESCOLA DE ARTES, CIÊNCIAS E HUMANIDADES

PROGRAMA DE PÓS-GRADUAÇÃO EM ESTUDOS CULTURAIS

PATRICIA GHUIDOTTE DE FARIA

O ESPECTADOR, AS SENSAÇÕES E A TEORIA DA AFECÇÃO

SÃo PAULO

2020 
PATRICIA GHUIDOTTE DE FARIA

O espectador, as sensações e a teoria da afecção.

Dissertação apresentada à Escola de Artes, Ciências e Humanidades da Universidade de São Paulo para obtenção do título de Mestra em Filosofia pelo Programa de Pós-graduação em Estudos Culturais.

Versão corrigida contendo as alterações solicitadas pela comissão julgadora em 25 de novembro de 2019. A versão original encontra-se em acervo reservado na Biblioteca da EACH/USP e na Biblioteca Digital de Teses e Dissertações da USP (BDTD), de acordo com a Resolução CoPGr 6018, de 13 de outubro de 2011.

Área de concentração:

Estudos Culturais.

Orientador:

Prof. Dr. André Fontan Köhler

\section{SÃO PAULO}


Autorizo a reprodução e divulgação total ou parcial deste trabalho, por qualquer meio convencional ou eletrônico, para fins de estudo e pesquisa, desde que citada a fonte.

Faria, Patricia Ghuidotte de

O espectador, as sensações e a teoria da afecção / Patricia

Ghuidotte de Faria ; orientador, André Fontan Köhler. - 2020

$130 \mathrm{f} .:$ il.

Dissertação (Mestrado em Filosofia) - Programa de PósGraduação em Estudos Culturais, Escola de Artes, Ciências e Humanidades, Universidade de São Paulo, São Paulo, em 2019.

Versão corrigida

1. Teatro - Aspectos psicológicos. 2. Spinoza, Benedictus de, 1632-1677. 3. Grupos teatrais. 4. Companhia Mungunzá de Teatro (Grupo teatral). 5. Antikatártika teatral (Grupo teatral). 6. Baskerville, Nelson, 1961-. I. Köhler, André Fontan, orient. II. Título

CDD 22.ed.- 792 
Nome: FARIA, Patricia Ghuidotte de

Título: $O$ espectador, as sensações e a teoria da afecção.

Dissertação apresentada à Escola de Artes, Ciências e Humanidades da Universidade de São Paulo para obtenção do título de Mestra em Filosofia pelo Programa de Pós-graduação em Estudos Culturais.

Área de concentração: Estudos Culturais

Aprovada em: 25 / 11 / 2019

\section{Banca \\ examinadora}

Prof. Dr. Artur Matuck

Instituição: Escola de Comunicações e Artes (ECA-USP)

Julgamento: Aprovada

Prof. Dr. Eduardo Okamoto

Instituição: Universidade Estadual de Campinas (UNICAMP)

Julgamento: Aprovada

Prof. Dr. Leonel Martins Carneiro

Instituição: Escola de Comunicações e Artes (ECA - USP)

Julgamento: Aprovada 


\section{AGRADECIMENTOS}

Agradeço imensamente a meu orientador, Prof. Dr. André Fontan Köhler, por ter me acolhido neste programa de pós, e por ter sido extremamente presente e disposto a me auxiliar durante toda a trajetória.

A Sonia minha mãe, que deixou parte de seus trabalhos por alguns meses para que eu ficasse tranquila em relação aos cuidados de minha filha, e pudesse terminar essa dissertação da forma que eu pretendia. Pela parceria, exemplo e amor de sempre, muito grata!

A minha irmã Daniele e ao meu cunhado Paulinho, que sempre me incentivam e me acolhem.

A Valdir, meu Pai que sempre me parabenizou feliz por minhas conquistas artísticas e acadêmicas.

A meus avós, Nair, Maria Aparecida, Juracy e Bernardino (in memorian), que não tiveram a oportunidade e o privilégio de estudar que tenho, mas que sempre se mostraram orgulhosos de meu percurso, e são pra mim detentores de um saber invejável.

A minha filha Emília, um sonho mesclado a este outro sonho de estudar na USP, a pequena de luz que dá sentido a meus dias; a ela, uma ideia de exemplo e incentivo.

Aos grupos pesquisados neste trabalho, Companhia Mungunzá e Antikatártika Teatral, que me receberam tão bem ao abrir seus processos, pensamentos e camarins. Especialmente a Verônica Gentilin, Thaís Medeiros e Hércules Morais que me atenderam na busca de informações durante todo o percurso da pesquisa.

Ao diretor Nelson Baskerville, que me recebeu de maneira muito gentil e simpática em sua casa, por sua entrevista generosa que norteou boa parte do trabalho, e por sua confiança ao dividir comigo situações íntimas familiares. Muito grata, Nelson!

A meu amigo irmão Fabiano Almeida, meu Rei, pessoa a qual me uni na faculdade e que tenho o prazer de ter a meu lado sempre.

A Daniela Querobina, querida que revisou este trabalho no período de qualificação com muito carinho e esmero.

Aos Queridxs Jéssica Botossi, Dinne Queiroz, Gabriela Leite, Michele Araújo e Sérgio Fernandes, que acompanharam-me do início ao fim nesta jornada.

Aos espectadores que gentilmente confiaram a mim suas experiências muitas vezes traumáticas, muito grata pela confiança.

A Querida Prof ${ }^{\mathrm{a}}$. Dr ${ }^{\mathrm{a}}$ Vivian Grace Fernandez Davila Urquidi, que me acolheu por um ano a seu lado nas salas de aula, por meio do Programa de Aperfeiçoamento de Ensino - PAE. A ela a minha gratidão pela linda parceria e por tudo que me ensinou, aprendizados muito além da sala de aula.

A Coordenação de Aperfeiçoamento de Pessoal de Nível Superior - Brasil (CAPES) que apoiou a realização deste trabalho. $O$ apoio aos pesquisadores é imprescindível, desejo profundamente que permaneça, muito obrigada.

A todxs professorxs que aceitaram estar na banca de defesa e de qualificação deste trabalho, pessoas pelas quais tenho muita admiração, imensamente grata pela generosidade em ler-me! 


\section{RESUMO}

FARIA, Patricia Ghuidotte de. $O$ espectador, as sensações e a teoria da afecção. 130 f. Dissertação (Mestrado em Filosofia) - Escola de Artes, Ciências e Humanidades, Universidade de São Paulo, São Paulo, 2019. Versão corrigida.

Esta pesquisa tem por objetivo investigar o que acontece no encontro entre $\mathrm{o}$ ator e o espectador usando a teoria da afecção de Spinoza como principal aporte teórico para análise. A ideia é poder contribuir com uma teoria filosófica possível para estudar o espectador e o fenômeno que se dá nesse "entre" que existe quando uma apresentação de teatro é levada a público. Buscou-se também entrevistar os grupos e direção dos espetáculos estudados, a saber: Luis Antonio-Gabriela da Companhia Mungunzá de Teatro e $A$ Vida da Antikatártika Teatral ambas com direção de Nelson Baskerville. Houveram cerca de vinte entrevistas com espectadores destas peças citadas, alguns encontros com os atores e uma entrevista com o diretor dos espetáculos. A partir disso o desejo é trazer uma possibilidade de interpretação que faça refletir a potência que o teatro possui e o que isso pode influir na vida quem $o$ assiste.

Palavras-chave: Espectador; Spinoza; Afecção; Potência; Teatro. 


\begin{abstract}
FARIA. Patricia Ghuidotte de. The spectator, the sensations, and the theory of affection. $130 \mathrm{f}$. Dissertation (Master in Philosophy) - School of Arts, Sciences and Humanities, University of São Paulo, São Paulo, 2019. Corrected version.

This research aims to investigate what happens when actor and spectator meet by using Spinoza's theory of affection as the main theoretical contribution for the analysis. The idea is to contribute to a possible theory to study the spectator and the phenomenon present in the "space between" when a play is performed to the public. Also, the groups and director of the plays studied were interviewed, they are: Luis Antonio-Gabriela of Companhia Mungunzá de Teatro and A Vida of Antikatártika Teatral and direction of Nelson Baskerville.There were about twenty interviews with the viewers of the plays mentioned, some meetings with the actors and an interview with the director. Based on that, the intent is to bring up a possibility of interpretation that allows us to think about the power that the theater has and how it can influence the life of who watches it.
\end{abstract}

Key-words: Spectator; Spinoza; Affection; Power; Theater. 


\section{LISTA DE FIGURAS}

Figura 1: Cena da peça Luis Antonio-Gabriela. Foto: Bob Sousa .................................. 39

Figura 2: Cena da peça Luis Antonio-Gabriela. São Paulo, 2016 .................................. 41

Figura 3: Cena da peça A Vida , TUSP, 2017, São Paulo. Foto: Ligia Jardim. ............ 46

Figura 4: Cena da peça $A$ Vida, TUSP, São Paulo 2017. Arquivo Antikatártika Teatral. 


\section{SUMÁRIO}

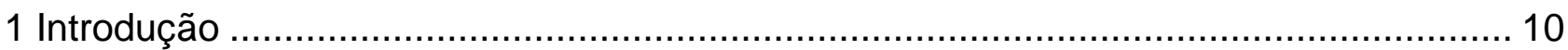

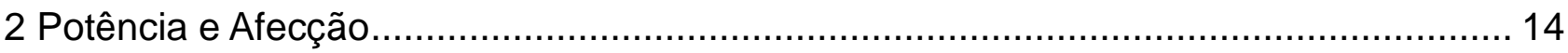

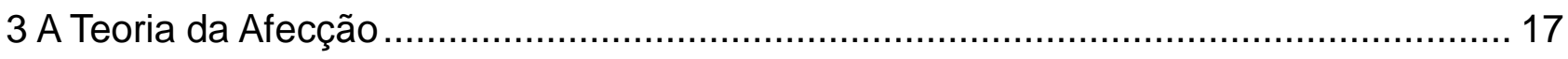

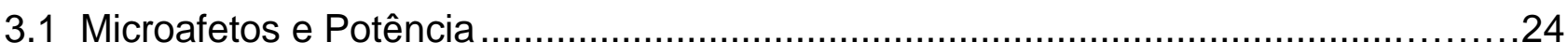

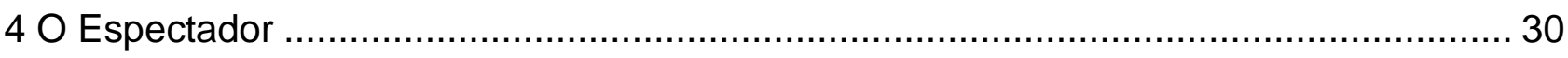

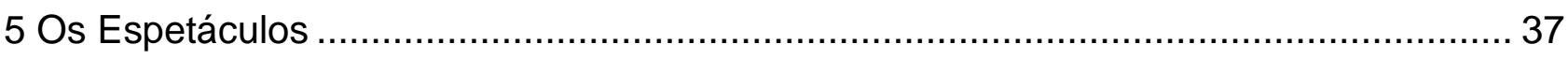

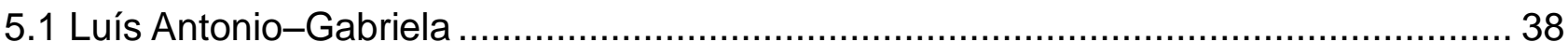

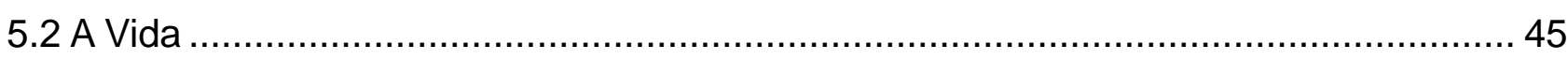

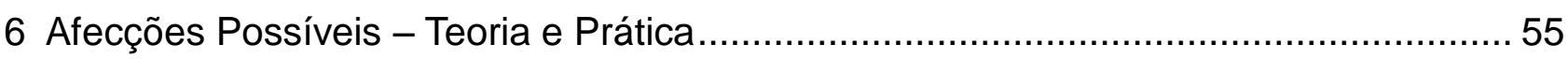

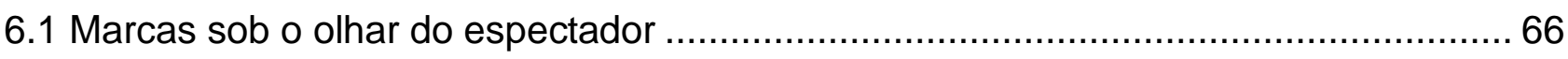

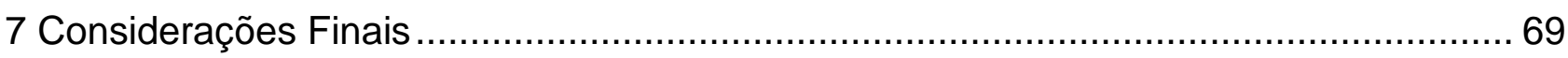

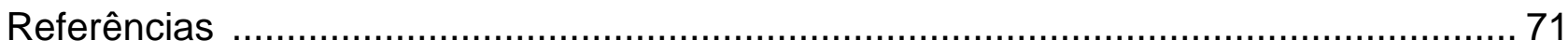

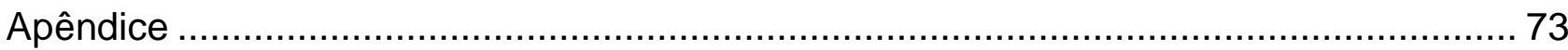

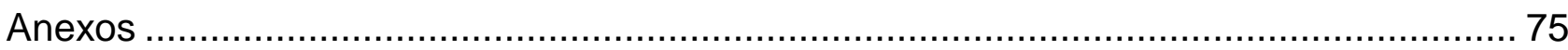

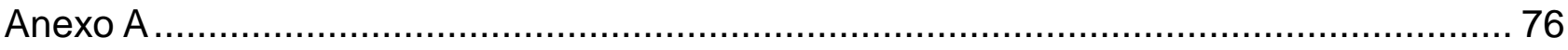

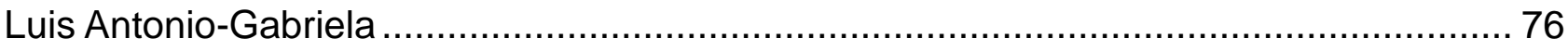

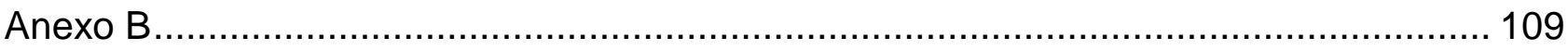

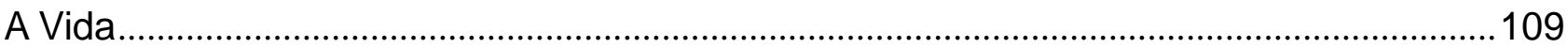




\section{Introdução}

Após ter sido afetada por diversos trabalhos teatrais e de dança ${ }^{1}$, fiquei interessada em investigar o que traz a estes trabalhos uma força que conecta e chama a atenção do espectador. Afirmo isto porque, em todos os trabalhos supracitados assistidos por mim, mais de uma vez, pude notar um envolvimento grande entre atores e espectadores que comungavam como num rito as ações que ali eram partilhadas. Interessa-me perceber quais são as práticas que os grupos adotam em seus processos de criação, e o quê o espectador que se afeta por estes trabalhos consegue traduzir em relação as suas sensações.

Para isso, foram escolhidos para prosseguir a pesquisa os espetáculos Luís Antonio-Gabriela e A Vida, por acreditar que para poder aprofundar os estudos da maneira mais ética e coerente possível, dois espetáculos estudados por meio de todo seu processo visando os grupos, a direção e os espectadores são o que seria possível dentro do período de tempo proposto para um mestrado.

Esta pesquisa nasceu do desejo de compreender parte de o que acontece com os espectadores, ao se depararem com um espetáculo teatral, partindo do princípio de que não é possível mensurar o todo de uma experiência. Neste momento, o desejo é investigar o que acontece e como se dá a ligação entre espectador e ator. Investigar o que ocorre, que pode vir a fazer, com que aquele que assiste se desprenda de qualquer pensamento exterior, por alguns instantes, por estar envolvido com as ações cênicas que presencia.

Para isso, fez-se necessário que os espectadores pudessem ser escutados, que partilhassem suas impressões e possíveis co-relações que, livremente, sem nenhum direcionamento prévio acerca de suas falas, pudessem ter relação com acontecimentos de suas vidas.

Essas relações eram passíveis de acontecer, porque os dois espetáculos escolhidos para este estudo lidam diretamente com acontecimentos da vida cotidiana de um sujeito, tais como traumas, separações, abusos, surpresas, acidentes, nascimentos, encontros e dificuldades, entre outras coisas.

É importante ressaltar que embora estes espetáculos tenham sua temática

\footnotetext{
1 - Espetáculos com a atuação de Eduardo Okamoto (Eldorado, Chuva Pasmada, Agora e na hora de nossa hora, Recusa e OE), Luiz Antonio-Gabriela da Companhia Mugunzá de teatro, A Vida da Antikatártika Teatral, Clarabóia de Morena Nascimento, Os Bem-Intensionados do Grupo Lume, entre outros.
} 
muito próxima a fatos cotidianos como foi dito acima, com base em outras percepções não estudadas profundamente aqui, mas também estudadas em espetáculos contemporâneos, como por exemplo, na dissertação e tese de Leonel Carneiro que serão abordadas mais adiante, é explícito e curioso como sempre, seja qual for a temática de um espetáculo, o espectador sempre faz uma ligação direta com a sua vida, a sua memória é sempre suscitada a atrelar os fatos assistidos com algo particular seu que remeta a uma sensação ou imagem de seu passado.

Os dois espetáculos aqui estudados são de grupos da cena teatral paulista a saber, a) Luís Antonio-Gabriela realizado pela Companhia Mungunzá, e b) A Vida, realizado pela Antikatártika Teatral. Ambos são dirigidos por Nelson Baskerville.

As obras de Nelson Baskerville possuem uma assinatura própria marcante; em geral, ele ativa o imaginário e sentimentos pessoais de maneira explícita. Os recursos cênicos utilizados por ele dificilmente fazem com que o espectador não se envolva. Os elementos são cuidadosamente colocados em cena para que possam contribuir, o máximo possível, com o modo no qual as histórias são contadas.

No livro de Alexandre Mate Mungunzá: Obá! Produção Teatral em Zona de Fronteira, Cleo Moraes destaca que Nelson Baskerville não receia em destruir a narrativa, combinando vários estilos, linguagens heterogêneas, performáticas e audiovisuais para resultar em um espetáculo atraente, vibrante, apesar de difícil compreensão e degustação. Mais adiante, Nelson Baskerville falará em entrevista para essa pesquisa, sobre a ideia que possui a respeito da "digestão" de seus espetáculos.

Estes espetáculos foram escolhidos como objetos de estudo para esta pesquisa, por condensarem fatores importantes de particularidades cênicas diferentes em suas estruturas e encenações, ainda que assinadas pelo mesmo diretor. Em alguns momentos, eles até formam uma possível conexão em relação ao gênero documental acentuado, mas as explorações e criações plurais motivam a analisar de perto estes processos de trabalho e suas possíveis reverberações.

É evidente que, de algum modo, o teatro está sempre tratando da vida. Ainda que se possa desmembrar suas muitas faces para tratar de um ponto específico, é sempre um jeito novo ou tentativa disso que se tem, um olhar muitas vezes reflexivo, para que seus espectadores possam se rever ou se ver nas atitudes e contextos apresentados, e possam, a partir disso, agirem diferentemente, caso lhes faça sentido. É neste ponto que conecto a ação do pôr em cena com a possível 
receptividade movida por um envolvimento mútuo, primeiramente dos artistas em seus espaços de ensaio, e, depois, por consequência, de seu público, causando assim uma afecção.

A teoria da afecção foi criada pelo filósofo Benedictus Spinoza, e é outra importante aliada pertinente ao pensamento desenvolvido na pesquisa. Nesta teoria, ele elucida os motivos pelos quais nos afetamos positivamente ou negativamente por algo, um encontro com corpos, que são tanto outros corpos em sentido literal (outras pessoas) quanto corpos não palpáveis, tais como fenômenos da natureza e até mesmo sensações que nos acometem.

A partir da hipótese de que um sujeito, ao se deparar com um "corpo espetáculo", poderá sofrer uma afecção que, segundo Spinoza, pode-se dar por uma lembrança de alegria, tristeza ou por um desejo (três principais afecções nomeadas por ele em sua obra Ética como afecções-paixão), o sujeito pode subjetivamente se deparar novamente com sua primeira afecção vivenciada, e, portanto, neste segundo momento, agir de forma diferente sobre ela, podendo assim elevar seu grau de potência, e, por meio disso, conseguir cada vez mais sua emancipação. Todo sujeito está sempre em constante construção; somos atravessados por diversas forças que nos constituem. Assim sendo, o encontro com um espetáculo também traz em si a possibilidade de emancipação, pois um atravessamento pode auxiliar no modo com o qual uma força pode compor com o aumento de gradação das potências individuais.

Para que o leitor possa ter conhecimento a respeito do percurso de leitura deste trabalho, terá a seguir a informação do que cada capítulo trata.

O primeiro capítulo que por uma norma técnica é na verdade a introdução da pesquisa que agora está sendo lida, na qual estão partilhadas com o leitor os desejos que motivaram esse trabalho e o caminho percorrido entre teoria e pesquisa de campo.

O segundo e o terceiro capítulos do trabalho tratam com intensidade de todo 0 aparato teórico usado para essa pesquisa, por acreditar que é importante iniciar a leitura fornecendo uma noção comum dos conceitos utilizados para que, posteriormente, as análises possam ser acompanhadas com facilidade. Neles serão expostos os principais conceitos e a teoria da afecção que é a teoria que embasa o trabalho.

O quarto capítulo trata do tema principal desta pesquisa, o espectador. Nele é 
esmiuçado o que se pretendeu com as entrevistas e conversas e um rápido mapeamento de quem são estas pessoas que hoje formam o público teatral no Brasil (pensando que há entrevistas de diversos estados do país pelos quais os grupos fizeram temporada, por exemplo: São Paulo, Rio de Janeiro, Espírito Santo, Ceará, Maranhão entre outros) e suas predileções por espetáculos com a linguagem que essas peças abordaram.

Nele também é tratado o Programa Vocacional, atualmente quase extinto por conta de nossa política precária, no qual os grupos forneciam formações e cursos para as pessoas das regiões onde se apresentavam, será visto, ainda que rapidamente, como esse projeto modificava e formava um espectador.

No quinto capítulo, os espetáculos estudados para a pesquisa serão abordados. Nele, estão contidos os desejos dos grupos para a criação dos espetáculos, o que os atores individualmente percebem de seus trabalhos em relação aos espectadores, suas hipóteses de afecções possíveis, a relação com o diretor e aspectos importantes das montagens, entre outras coisas.

No sexto capítulo são fornecidas as entrevistas dos espectadores, foram cerca de vinte abordagens, com mais de uma conversa cada uma, desta forma os espectadores podiam elaborar e assentar melhor algumas ideias e sensações de acordo com o que thes eram mais latentes depois de assistir os espetáculos.

É neste capítulo também que busco traçar algumas análises das afecções com base na teoria de Spinoza. Existe também o enlace de algumas falas dos atores dos espetáculos que surgiram por meio de relatos que tiveram pessoalmente com alguns espectadores que os procuraram. 


\section{Potência e Afecção}

A palavra potência vem do latim Potentia. Segundo o Dicionário de Filosofia de Thomas Mautner (2010), em Aristóteles, a potência está atrelada à potencialidade, um poder no interior de algo que se esforça para se tornar efetivo, para se manifestar. Já no livro locus classicus, os exemplos centrais dados por Aristóteles estão atrelados à biologia; por exemplo, uma aranha é potencialmente uma tecedora de teias. Isto é verdade, mesmo que algumas ou a maioria das aranhas não sejam efetivamente tecedoras - talvez a maior parte delas pereça antes disso.

Já no dicionário Aurélio da língua portuguesa (1999), a potência é um conjunto de aptidões ou elementos próprios para produzir um ser ou um ato, e pode significar poder, força, vigor, estado e/ou capacidade de realizar. Características geradoras de uma obra feita de maneira intensa e com sentido pleno por aquele que a pratica, o que pode possibilitar uma relação de afeto em seu encontro com o receptor, na construção da apresentação, tornando-a mais simples e, principalmente, menos dependente de elementos artificiosos.

Para Spinoza² (2013), a natureza é a virtude dos afetos. Segundo ele, existem três afetos primários, a alegria, o desejo e a tristeza - fatores reguladores para aquilo que se tem afeição ou repulsa, maneiras de afetos nos quais um mesmo objeto pode ser causa de muitas e conflitantes afetividades.

Desta forma, estes afetos primários são fatores com os quais o corpo pode ser afetado, e que o estimulam, aumentando ou diminuindo sua potência de agir. Os afetos se dão por uma memória do corpo que é ativada, gerando aproximação ou repulsa.

O presente estudo nasce da vontade de relacionar este pensamento filosófico ao teatro, pois se tem observado que o espectador está sujeito a sofrer um contágio em nível físico e psicológico, que pode estimulá-lo a perceber e resgatar suas próprias experiências obtidas até então. Relaciono esta hipótese ao pensamento de Spinoza, quando este exemplifica o processo de afecção em cada regulador primário:

\footnotetext{
2 - Benedictus de Spinoza 1632- 1677. Foi um dos grandes racionalistas do século XVII dentro da chamada Filosofia Moderna, o filósofo da imanência. Sua teoria é a principal fonte de estudos desta pesquisa.
} 
$\mathrm{Na}$ afecção provida de alegria, a mente passa por uma perfeição maior, referida a mente e ao corpo. $\mathrm{Na}$ afecção provida de tristeza a mente passa por uma perfeição menor, referida a dor e a melancolia. Já na afecção provida do desejo a mente busca se alimentar do apetite e vontade que conscientemente se tem. (SPINOZA, 2013, p.137)

As produções teatrais dispõem de uma ampla gama de possibilidades técnicas que apresentam artifícios cênicos para a construção dramática e para a própria concepção do espetáculo, tipos de linguagem e maneiras de pôr em cena diversas - mas parece que as situações que apresentam mais envolvimento entre 0 espetáculo e o espectador ocorrem quando estão em jogo as potencialidades do corpo que se mostra despido de grandes artificios, mas está ali presente e disposto à troca mútua muito mais do que para apresentar sua técnica, no sentido do virtuosismo.

É sabido que o corpo de um ator é parte fundamental em sua exposição pública. Tornar esta atuação sensorialmente interessante e tonificada passa a ser parte de uma ação prática completa, que se dá por meio de um treino não apenas físico, mas também teórico e psicológico; práticas que vão de palestras entre os grupos que retratam o tema escolhido para o trabalho até pesquisas de campo e treinos físicos direcionados.

Segundo Gilles Deleuze, quando um corpo visível enfrenta, como um lutador, as potências do invisível, ele lhes dá sua visibilidade, é como se a partir disso um combate se tornasse possível (Cf. DELEUZE, 2007, p.67).

Com base nisso, pode-se pensar que a potência, para além de estabelecer uma conexão entre ator e espectador, preenche também o espaço e pode fornecer condições de sentirmos no espaço algo que momentaneamente ganha força e conecta o público ao espaço, de maneira que sua percepção se dilate por alguns instantes, e o faça, ao menos, sentir-se diferente por um curto período de tempo que pode ser registrado em si como uma chave de mudança ou não.

Questões como esta falta de potência e até de um rigor com a exposição de um ator ao público tornam a busca do ato potente relevante para o trabalho de artistas que desejam provocar no público um desengate de consciência ${ }^{3}$, uma

\footnotetext{
3 - Utilizo aqui o termo desengate de consciência com a ideia de pensar uma provocação advinda da cena, que faça com que o espectador rompa com um padrão anterior de pensamento, e, a partir daquele momento, passe a questionar-se e possa mudar sua maneira de agir e conduzir acontecimentos de sua vida.
} 
modificação no raciocínio comum ou linear, uma proposta artística que possa fazer pensar diferentemente do que antes, dando abertura para a descoberta de novas percepções e novos pontos de vista em sua realidade cotidiana, expandindo de si para a multiplicidade de suas relações, e para o espaço que ocupa.

Para um aprofundamento nas questões do ato potente, é importante olhar, embora existam fatores teóricos e psicológicos, para o comportamento do ator sob a ótica da potência que deriva principalmente do trabalho de seu corpo, da ação e prática anterior ao trabalho específico para a apresentação, e perceber onde acontece a divisão de estados cênicos (potente versus não-potente), e o que qualifica um ato como potente.

Partindo do princípio de que os afetos ativam a memória do corpo, são, portanto, fatores imprescindíveis para que essa potência ganhe conexão com aquele que aprecia um espetáculo teatral. É por meio destes fatores reguladores, citados acima, que o espectador se depara com uma realidade que, mesmo não sendo sua, pode remetê-lo a um lugar de si que o deixa em contato, por alguns instantes, com o que está acontecendo naquele momento. 


\section{A Teoria da Afecção}

Em seu mais conhecido livro, denominado Ética, o filósofo Benedictus de Spinoza fornece ao leitor uma ideia de ética de vida, escrita segundo proposições geométricas e dividida em cinco partes, a saber:
I. Deus
II. A Natureza e a origem da mente
III. A Origem e a natureza dos afetos
IV. A Servidão Humana ou a força dos afetos
V. A Potência do intelecto ou a liberdade humana

Lidaremos nesta pesquisa, predominantemente, com as terceira e quarta partes, por estarem nelas contidas os pensamentos acerca dos afetos e suas dimensões. É por meio delas que se pode compreender a estrutura do conceito de natureza de Spinoza, da qual tudo que existe no mundo se forma, e que será apresentada adiante.

Um dos conceitos mais investigados, entre os leitores de Spinoza e de fundamental entendimento para leitura de suas obras, é o conatus, que defende em si a ideia de que tudo que existe no mundo se esforça para continuar a existir e perseverar em seu ser.

Amauri Ferreira explicita este conceito com base em uma análise de duas proposições da Ética, em seu livro: Introdução à Filosofia de Spinoza:

A essência atual do corpo é, assim como a da mente, o seu próprio
esforço. Ora, a essência atual de qualquer coisa singular existe em
ato, em qualquer atributo da substância, é o esforço para perseverar
em seu ser ou em sua natureza: "O esforço pelo qual cada coisa se
esforça por perseverar em seu ser nada mais é do que a sua
essência atual" (Ética, 3, Prop. 7). "Esforço é a tradução de
"conatus". Tudo que existe se esforça por um tempo indefinido para
permanecer em sua natureza: "Portanto, o esforço pelo qual uma
coisa existe não envolve, de maneira alguma, um tempo definido,
mas pelo contrário, ela continuará, em virtude da mesma potência
pela qual ela existe agora, a existir indefinidamente, desde que não
seja destruída por nenhuma causa exterior. Logo esse esforço 
envolve um tempo indefinido" (Ética,3 Prop. 8, dem.). Tal esforço apenas é interrompido por um conatus de uma outra coisa singular: a morte sempre é exterior ao modo finito. (FERREIRA, 2009, p. 55)

Para Spinoza, este esforço vindo do conatus é denominado apetite, se estiver ligado a relações de encontros que se dão pela mente e pelo corpo, simultaneamente. Já se esse esforço estiver ligado apenas a mente, ele o denomina vontade. Quando o apetite torna-se consciente em nós, Spinoza o chama então de desejo (FERREIRA, 2009, p.56).

A partir destas composições de persistências de tudo que existe perseverar para se manter em seu ser, é importante expor o conceito de Deus, que, para o filósofo, trata-se da natureza; tudo que existe é chamado de Deus e pode ser substituído por natureza.

É interessante ressaltar que Spinoza escreve no século XVII e que suas ideias eram bastante subversivas para a epóca. Essa foi a maneira pela qual ele tentou expor seus pensamentos, sem que fosse interrompido de realizar os trabalhos, já que, de fato, o conceito de Deus em sua concepção só poderia fazer sentido aliado a tudo que existe no mundo, e não à figura de um único ser espiritual e mágico. Contudo, isso só foi possível até o momento em que ele foi lido, pois, quando isso aconteceu, inúmeras persguições se deram contra ele, e ele foi excomungado, tendo inclusive em sua anátema de herege além da proibição de qualquer auxílio, a proibição de que seus escritos publicados fossem lidos por qualquer seguidor de Adonai ${ }^{4}$.

A partir das composições advindas do desejo, quando se tem minimamente consciência deles, acontecem as afeç̧ões, que se formam de tudo que compõe essa natureza (Deus), e que é regida por mais duas afecções-paixão: a alegria e a tristeza. É fundamental evidenciar que o afeto-paixão desejo não tem nenhuma ligação com falta; pelo contrário, ele é nascido de um encontro com um ou mais corpos, considerando corpos tudo que existe tal como fenômenos da natureza, pessoas, cheiros, entre outras coisas, às quais a pessoa já possui, e isso aumenta ainda mais sua potência em existir. $O$ mesmo se dá com a afecção de alegria e

\footnotetext{
4 - Adonai é um termo hebraico que significa "meu Senhor". Este era o nome de Deus usado no antigo testamento em vez do nome divino de Javé (Yahweh), uma vez que este, por respeito, não se devia pronunciar.
} 
tristeza. A afecção só acontece quando o sujeito tem um choque com outro corpo que o marca, a partir de um encontro.

Um sujeito se esforça o tempo todo para aumentar sua potência de agir, ainda que não tenha consciência plena disso. O corpo de um ser humano, assim como um corpo animal, está o tempo todo tendo ações que buscam aumentar suas potencialidades. Isso, para Spinoza, faz parte de nossa natureza, que é um pedaço de Deus em nós, considerando que não existe a entidade Deus fora de um plano existente e material. Tudo que existe é Deus. E Deus está em tudo por ser natureza.

Por sermos uma parte desta natureza, somos determinados por ela. Coisas fora do sujeito indicam que a potência de algum modo tem seu limite; por exemplo, quando sentem frio, as pessoas se agasalham, quando sentem sede, bebem água, e assim ocorre com tudo que ocasionalmente pode acontecer por natureza. Sendo tudo parte dela, da mesma protege-se com os recursos existentes, mas nunca se está aquém da possibilidade de sermos determinados por fatores externos, conforme exemplificado acima.

Não temos uma potência ilimitada - outras coisas nos excedem - por isso é necessário que um sujeito tente selecionar, ainda que minimamente, seus encontros, pois, de qualquer forma, outros corpos sempre irão de encontro a ele. Isso é inevitável, mas existe a possibilidade de algumas coisas possíveis serem selecionadas.

Algo que auxilia neste sentido é a ideia de noção comum. A partir da compreensão universal de um sistema regido por códigos para uma sociedade, entende-se que se respeita, ou deveria, normas como: sinalizações de trânsito, espaços de convivência pública e modos de utilizar objetos, entre outras coisas.

Existe também a lei da natureza, que é, segundo o filósofo Spinoza, objetivamente racional. É pouco provável, por exemplo, que alguém sobreviva à queda de um prédio de vinte andares. Essa é a lei da natureza. É sabido que, se isso ocorrer, um óbito se dará.

A teoria da afecção acaba então por se tornar um modo passível de entendimento das coisas que acontecem, e de escolha de ações que podem aumentar ou diminuir a potência de um sujeito. Todos nossos encontros com o mundo nos provocam uma afecção, e, ao passar pelas experiências, essas afecções podem ser trabalhadas para que, cada vez mais, as afecções que decompõem sejam mantidas a distância. É importante mencionar que não existe uma relação 
maniqueísta com estes encontros, pois nada é bom ou mal em si, o que não compõe com um sujeito pode perfeitamente compor com outro. O filósofo Peter Pal Pelbart traz um pouco de Spinoza, a respeito das composições:

\begin{abstract}
Somos um grau de potência, definidos pelo poder de afetar e ser afetado. Mas jamais saberemos de antemão qual é a nossa potência. Do que somos capazes é uma questão de experimentação. Não sabemos ainda o que pode o corpo, diz Spinoza, só o descobriremos no decorrer da existência. Ao sabor dos encontros. Só através de encontros aprendemos a selecionar o que convém, o que não convêm, o que com ele se compõe, o que tende a decompô-lo, o que aumenta sua força de existir, o que a diminui, o que aumenta sua potência de agir, o que a diminui. (PELBART, 2008, p.33)
\end{abstract}

Existem também os afetos-ação, que são os afetos secundários aos três principais denominados afetos-paixão. O que os distingue é que o primeiro é causado sempre por afecções da mente e o segundo por afecções corpóreas. Spinoza defende que deve-se buscar as ideias adequadas para as ações, isto é, uma compreensão do modo de se afetar por coisas que causem composição, quebrando hábitos e se permitindo afetar por coisas novas, não apenas por afetospaixão, mas por afetos-ação que se conectam com a mente, mais do que o inesperado modo corporal. Sendo assim uma afecção-ação é uma causa adequada de uma afecção corpórea; ela foi processada mentalmente, contribuindo para o aumento de potência do sujeito. Quando isso não ocorre, ela tende a decompor com o sujeito e diminuir sua potência, pois o sujeito, segundo Ferreira (em seu curso Spinoza, mente e corpo): "acaba por se tornar um servo de sua afecção-paixão" (informação verbal).

É sabido que as afecções-paixão possuem três únicos reguladores primários: alegria, tristeza e desejo. Já as afecções-ação são inúmeras, pois as afecções da mente sofrem um impacto que, por sua capacidade de interpretação, desdobram-se em muitas outras similares e possíveis. Um exemplo disso se dá no que Spinoza chama de Causa interior imaginária, por exemplo, o contentamento íntimo, no qual o sujeito passa a ter escolhas compostas por ideias adequadas e sente satisfação consigo mesmo, não por ter sofrido uma afecção corpórea (afecção-paixão), mas por ter tido uma afecção de sua mente que o impulsionou a tais maneiras de seleção, 
que o deram satisfação pessoal.

A luta de Spinoza é para que nos tornemos causas adequadas de nossas afecções, esforcemos-nos para perseverar em nosso ser; mas este esforço não pode estar descolado de nossa essência natural. Quando o sujeito não se organiza de acordo com sua natureza singular, fica dependente das afecções-paixão que tomam seu corpo para si, e não o permitem evoluir. Já quando ele consegue ser causa adequada de suas ações, sente uma alegria ativa, que não é ignorante porque não depende mais das afecções corpóreas que lhes são causadas.

Spinoza também diz que somos desejo - este é o primeiro afeto-paixão. A nossa natureza é desejante, somos compostos de muitos corpos, e estes corpos inteiros que nada faltam em si mesmos, tratando aqui de um corpo que busca suas ideias adequadas, desejam outras coisas que lhes ampliam.

Contudo, existem também os desejos imoderados, que excitam apenas uma parte do corpo. Esses desejos estão distantes das escolhas de ideias adequadas, e tornam o sujeito enfraquecido de potência e ignorante de si mesmo, sendo eles: gula, embriaguez, avareza, luxúria e ira, entre outros, que são excessivos levados em consideração por coisas que o sujeito pensa "amar", por conta de uma afecção não adequada para seu crescimento pessoal.

Ainda tratando do desejo, um conceito muitas vezes mal compreendido, Pelbart, que pensa Spinoza por meio das leituras que faz de Deleuze, diz que o desejo é movente, molecular, uma composição no campo de imanência: "O desejo atravessa o ser humano, quando você diz que deseja em primeira pessoa, você já traiu o desejo, ele só é atingido quando eu não posso dizer eu"(informação verbal). É importante lembrar que o desejo não comporta qualquer falta, ele é uma potência, transborda, por isso se compõe, e não porque algo falta e precisa ser completado.

A Ética de Spinoza, contempla também um encadear de pensamento muito importante, que fornece sustentação para analisar os afetos e os compreender, a partir de suas diferenças e complexidades. Existem na obra três gêneros de conhecimento, que balisam o "descobrir-se" de um ser. Todos eles possuem suas características, e é possível notar que a dificuldade em os transformar em ação fazem constatar como a maioria das pessoas vivem em seu primeiro gênero, aquele que exige menos esforço cognitivo, mas que também menos possui chance de se emancipar.

O primeiro gênero de conhecimento é a imagem ou o signo em certas 
interpretações de entendimento. Todo sujeito se esforça para conhecer o novo; para isso, existem as noções universais que auxiliam todos a conhecerem as coisas, então temos a figura cachorro, árvore, cadeira, e, apenas ao ter essas palavras lidas, nosso cérebro já nos traz a imagem delas; a imaginação é um aporte no qual sempre se recorre. Ainda que sem premeditar, os passageiros de um avião não consigam visualizar as casas abaixo de si com nitidez, o trabalho de imaginação é tão potente que isso acontece sem grandes esforços, por meio da imaginação é possível se aproximar de imagens semelhantes. Isso pode ser extremamente nocivo quando não acontece um salto para os outros gêneros de conhecimento, pois o conhecimento universal generaliza as coisas. Existe aí uma vulgarização, que sai de uma coisa para outra, que não é criada por imagem semelhante. Pelbart, tendo por base as palavras de Spinoza, chama isso de conhecimento inadequado. Está extremamente ligado a paixão (afecção) na qual não se reconhece algo que dela possa dar um salto, pelo contrário, torna-se refém dela.

O segundo gênero de conhecimento é a razão. Ela está mais centrada em analisar o efeito que as coisas produzem, e, a partir disso, extrair de fato conclusões para decisões a respeito de si. Ela é considerada um conhecimento adequado e mais ligado à luz, à ação e à busca de causas que componham com o corpo. Está ligada também às noções comuns, mas tem um funcionamento diferente na mente, pois se dá por meio das relações, à medida em que você se vê atrevessado por situações e não no campo da imaginação. Pelbart diz em seu curso Espinosa, pensador do presente que estamos mergulhados no primeiro gênero até o pescoço, mas não condenados a ele.

Por último, temos o terceiro gênero de conhecimento, que é a liberdade, ou, novamente para algumas interpretações, a essência e a singularidade. Ele é o último gênero e o mais difícil de ser atingido, segundo as próprias palavras de seu criador:

Aqui tratarei, portanto, como disse, apenas da potência da mente, ou da razão,e mostrarei, sobretudo, qual é o grau e a espécie de domínio que ela tem para refrear e regular os afetos. Que não temos com efeito, um domínio absoluto sobre os afetos foi o que demonstramos anteriormente. Os estoicos, entretanto, acreditavam que os afetos dependem exclusivamente de nossa vontade e que podemos dominá-los inteiramente. Contudo, viram-se obrigados, na verdade, não por causa de seus príncípios, mas diante das evidências das experiências, a admitir que não são pequenos 0 
exercício e o esforço necessários para refrear e regular os afetos, conclusão que um deles tentou demonstrar (se bem me recordo), pelo exemplo de dois cães: um, doméstico;de caça,o outro. $O$ resultado foi que pelo exercício, ele acabou conseguindo que o cão doméstico se acostumasse a caçar e que o de caça, em troca, deixasse de perseguir as lebres. (SPINOZA, 2013, p.213)

Pelbart diz que não temos um grau de potência, mas que somos um grau de potência. A natureza da qual faz parte a liberdade não pode ser cortada, é uma espécie de luz pura. Ela não serve para auxliar, aparece por si própria, e ilumina tudo, é uma potência absolutamente infinita, o próprio Deus (natureza). Diante da extensão de potência de cada um a ser preenchida, é sabido, até mesmo por meio das sensações, que a tristeza a diminui, e a alegria a aumenta. O sujeito chamado por Spinoza de sábio opta sempre pela que a aumenta. O sujeito passa a ser, inclusive, algo menos importante, pois ele é o meio pelo qual as coisas atravessam. Félix Guatarri diz: "Não importa o lugar de fala, não importa o que se fala, mas o que fala através de nós". Pelbart completa ainda dizendo que somos uma condensação de elementos heterogêneos do mundo inteiro, que existe uma força anônima que não pertence a ninguém. É por meio do modo que se é afetado que se compõe ou não; isso dependerá de como o sujeito se relaciona à medida dos encontros com outros corpos, quando ele está no terceiro gênero de conhecimento, cria uma conexão de modo a aproveitar seus encontros, fazendo com que sua potência seja aumentada.

É algo que ninguém pode fazer por um indivíduo, apenas ele mesmo, e para Spinoza isso é sinônimo de liberdade, serve, em sua visão, para absolutamente tudo - para estudar, para se relacionar, entre outras coisas, pois é compreender e a partir de então, buscar um modo de ser afetado que cause composição. Isso se dá quebrando hábitos, permitindo-se ser afetado não apenas por afecções-paixão, mas por afetos ações, como o filósofo mesmo diz conforme a citação acima, isso não é algo conquistado que permanece estático, é necessária uma vigilância constante para que os afetos-paixão não causem servidão. 


\section{1 - Microafetos e Potência}

O que cada espectador poderá sentir ou rememorar no contato com uma obra artística não pode ser previsto. O corpo não manda na potência, ela age sozinha, a partir do que já foi experienciado pelo organismo, por meio das vivências pessoais e, neste caso, artísticas de cada sujeito.

Existem diversas maneiras de se pensar a potência na expressão artística, mas o que interessa detectar e refletir é a relação constante com o modo de expressão corporal e com a dinâmica entre elenco e público, em sua mútua afecção. $O$ ator e pesquisador Renato Ferracini diz que essa relação se dinamiza quando o ator concentra suas experiências, voltando seu foco para as microssensações e microafetos. Em seu livro Ensaios de Atuação, ele divide alguns pilares e intensificações de caminhos para pesquisa que elucidam esse pensamento:

O foco de suas experiências deve estar voltado para as microssensações, microafetos. Sua potência deve estar localizada, territorializada em sua capacidade de ser afetado, ou seja, em sua capacidade de deixar-se afetar pelo espaço, tempo, outro. Gerar poros de entrada em seu corpo para que esses afetos sejam seu material de trabalho primeiro. O ator, portanto, não é uma fazedor profissional de ações, pois esse não é seu objetivo primeiro (aprender técnicas codificadas), mas é um atleta afetivo. Aquele atleta que se deixa afetar, que se territorializa em seu limite de sensação, recompondo-a. E então, age com essa recomposição da sensação, atua com e em formas de força, deixando-se afetar por elas mesmas. (FERRACINI, 2013, p.31)

De alguma forma, o corpo do ator precisa estar em conexão com o externo, o fora, aberto a uma relação que propõe a novidade do encontro e a tudo que o entorno proporciona, para que, poroso, o artista possa absorver e devolver ao público seu tônus atuante. Não há dúvida de que, ao afetar, o artista é simultaneamente afetado, e, a partir disso, novos acontecimentos tornam-se fatores de criação e de possíveis modificações na construção da intensidade desta afecção:

Se alguém fez algo que imagina afetar os demais de alegria, ele próprio será afetado de alegria, que virá acompanhada da ideia de si próprio como causa, ou seja, considerará a si próprio com alegria. Se contrariamente, fez algo que imagina que afeta os demais de tristeza, considerará a si próprio com tristeza. (SPINOZA, 2013, p.118). 
$O$ ato de estar imerso e focado em uma ação e, ao mesmo tempo, em contato com o espectador exige que o ator entre em um limite, que Ferracini chama de consciente-inconsciente. Para ele, trata-se de uma zona de fluxo constante, que faz parte do campo do ator, sobretudo no espaço de ensaio. Trata-se de uma passagem a um campo de virtuosidade que não tem ligação com excelência de uma prática específica, mas com a possibilidade de acessar uma zona de turbulência muito potente para os trabalhos (FERRACINI, 2013, p.31).

A partir desta distinção corpórea, caberá à atitude deste volume instável que é o corpo do ator fazer emergir esta força que se denomina potência, que atuará no espaço provocando o desengate de consciência, que pode possibilitar ao espectador entrar em contato com suas memórias que ativam os afetos, introduzindo uma nova sensação que abra uma fenda na realidade contínua de seu espaço, dando-se por meio mental e psicológico, visto que o espectador pode passar a refletir mais sobre os temas que the foram propostos, se assim o desejar.

A intensificação dois citada acima e as demais intensificações e pilares trazidos por Ferracini em sua obra são olhares pontuais para o trabalho de ator, que, de algum modo, mas não exatamente nestes termos, são trabalhadas por Baskerville em sua direção e também nos exercícios de preparação e montagem dos espetáculos com os grupos. Trabalhos que exigiram dos elencos uma abertura muito grande de seus espaços de percepção. Esses atores afetivos precisaram buscar suas fissuras internas, mexer com elas, falar sobre dores e traumas, e as transformar em cena por diversas vias: cartas, músicas, experiências corporais, vídeos e entrevistas com familiares, entre outras coisas, até que se tornassem cena.

$\mathrm{O}$ ator e Mestre em Psicologia, Hércules Morais (Antikatártika Teatral) aponta em sua dissertação de mestrado intitulada: Como olhos de cotidianos se tornam olhos estéticos? Processos artísticos como processos de invenção de sentidos sobre o mundo, outra maneira interessante do trabalho do ator que pode ser aplicado e experenciado para dar vida à uma cena:

Peguei uma folha de papel e desenhei um corpo e fui fazendo marcas nele, e depois perguntei ao grupo o que eram aqueles riscos? Por exemplo: "uma operação no joelho", "a separação de meus pais", "calçado apertado", "mochila pesada", "morte de minha avó", etc. ĺamos pensando estas marcas como vestígios do 
fenômeno da experiência do corpo em relação ao mundo, marcas de origem física e ou psicológicas.

Todos carregamos marcas de nossa história, o objetivo da caminhada é tentar perceber estas marcas, para que a partir da compreensão e verificação destas marcas o participante possa reconfigurar ou reconhecer suas potencialidades criativas. O que meu corpo conta sobre mim ao mundo? O que comunico com minha postura? Como posso a partir do trabalho corporal agir sobre essas mensagens? (MORAIS, 2017, p.50)

Ainda que a prática proposta por Morais (2017) seja feita para os atores, ao assistir o espetáculo, os espectadores também possuem a oportunidade de revisitar os fatos que Ihes aconteceram ao longo de sua trajetória de vida.

Essa comunhão de acontecimentos pode fazer com que a dramaturgia ou mesmo a encenação dialogue de maneira mais direta e proporcione uma reflexão (se existir uma disponibilidade interna de cada sujeito para isso), pois em geral, não é dado às pessoas ferramentas e tempo para que rememorem acontecimentos importantes de suas vidas, nem sequer de silenciarem para que suas emoções ecoem.

Já na atividade prática que o teatro traz, frente a frente, sem dispositivos de dispersão como faz a televisão, é que ele tem chance de investigar-se, descobrir suas próprias fissuras e talvez, de algum modo como fizeram os atores, fazer algo com isso de acordo com suas potencilalidades, partindo do princípio de que o ator levou isso à cena, e individualmente de acordo com suas habilidades quem vê pode desdobrar em alguma outra ação que Ihe seja pertinente e eficaz.

\section{2 - O Conceito de Espanto}

Seria a mistura no palco de tudo que está misturado na vida... seria o riso; seriam as lágrimas; seria o bem, o mal, o alto, o baixo, a fatalidade, a providência, o gênio, o acaso, a sociedade, o mundo, a natureza, a vida; e, acima de tudo isso, sentiríamos pairar algo de grande! (ROUBINE, 2003, p.104).

Os dois espetáculos citados neste estudo trazem essa mistura de vida real à cena, sem máscaras e sem artifícios enganosos para denotar alegria nem sequer 
amortecer os impactos sofridos cotidianamente. E disso algo surge algo que se assemelha ao espanto, ao não saber o que fazer, ao suspender os pensamentos por algum instante.

Ruth Rohl afirma, que a partir de 1970, Heiner Müller ${ }^{5}$ firma seus textos literários e teatrais contemporâneos como documentos de seu tempo "um tempo de crise, em que tudo espera por história". Ele situa então nas palavras de Rohl: "O terceiro mundo, com todos os problemas de fome e superpopulação”, ouso dizer, ao deslocar para o século XXI que de violência também, como podemos novamente rememorar com as descrições e depoimentos dos espectadores acerca dos fatos que as peças descritas aqui suscitaram. Fala também da importância do teatro trazer à cena efeitos e textos fragmentados, de modo a não permitir que a história se reduza apenas ao palco:

O fragmento torna-se produtor de conteúdos, abrindo-se à subjetividade do receptor, correspondendo ao que Müller chama de "espaços livres para a fantasia", em sua opinião uma tarefa primariamente política, uma vez que age contra clichês préfabricados e padrões produzidos pela mídia.

O trabalho com o fragmento provoca também a colisão instântanea de tempos heterogêneos, possibilitando a revisão crítica do presente à luz do passado. São muitos os testemunhos de Müller a respeito da necessidade do trabalho da memória; segundo ele, a memória de uma nação não deveria ser apagada, pois isso significaria a sua sentença de morte. Mas não é apenas nesse sentido que se faz indispensável dirigir o olhar para o passado: em sua opinião, para se livrar do pesadelo da história é preciso conhecê-la e dar-lhe o devido valor. (KOUDELA. 2003, p.34)

Neste trecho, Koudela fala de um fator sociológico que age por meio das ações individuais que são cometidas, e sobre a maneira por meio da qual se pode lidar com essa memória do que um dia atinge um sujeito e para uma emancipação agregadora não deveria ser superado a partir do ocultamento do fato ocorrido, mas de um debruçar-se sobre, ainda que traumático, se pensarmos na história de grandes guerras e ataques, apenas analisando os fatos, conhecendo-os e os

\footnotetext{
5 - Heiner Müller 1929-1995. Dramaturgo e escritor alemão. Sua carreira literária teve início quando o socialismo estava sendo construído na República Democrática Alemã. Müller é considerado um discípulo e seguidor da obra de Bertolt Brecht.
} 
nomeando é possível avançar.

Rohl (2003) também cita que os críticos alemães unindo Müller a Brecht e Artaud nomeiam as obras desta tríade como os autores que enfatizam na cena a "valorização da poética do corpo". A linguagem poética oferece um envolvimento sutil, e, enquadrados nesta perspectiva de encenação conectada a ideia de terceiro mundo e seu caos de acontecimentos, Müller acredita que seria isso o fermento do novo, diante do mais terrível caos social e/ou psicológico aponta a mudança, quando nada mais pode evoluir e tudo se esgota, algo novo está próximo a nascer.

Vários depoimentos dos espectadores mostraram que, diante do choque revivido durante as peças, puderam tomar a iniciativa de fazer algo novo com aquele "caos" de suas dores, e, de algum modo, o esgotamento da questão se deu e trouxe uma nova solução, como o caso da espectadora Gabriela por exemplo, que abriu o caso de abuso familiar sofrido por ela após anos, como veremos adiante; disso decorre uma nova experiência, uma nova possibilidade.

Ingrid Koudela diz: "A primeira forma de esperança é o medo, a primeira aparição do novo, o espanto" (Cf. KOUDELA, 2003, p.48). Ainda que "maquiado", o medo surge como uma disfarçada maneira de esperar que algo aconteça, o novo intercepta, faz tudo parar, é o espanto que assombra, e, em um segundo momento, faz agir.

Para Antoine, a encenação pode contribuir de diversas outras formas para o contato da obra com o espectador de um modo atrativo, não denominadas exatamente como afecção ou assombro, mas que resultam igualmente em um impacto:

[...] uma das maiores contibuições de Antoine para a encenação moderna consiste na sua rejeição do painel pintado e dos truques ilusionistas habituais no século XIX. Ele introduz no palco objetos reais, ou seja, que contêm o peso de uma materialidade, de um passado, de uma existência. Trata-se, sem dúvida, de produzir um efeito mais verdadeiro. Ou, melhor ainda, totalmente verdadeiro. Mas, ao fazê-lo, Antoine revela algo que o teatro do século XX não poderá mais esquecer: aquilo que poderíamos denominar a teatralidade do real. (ROUBINE, 1998, p.29)

Essa ideia de teatralidade real e materialidade do passado dialoga muito com a teoria de Spinoza a respeito do despertar da afecção de um ser.

Pois a materialidade do passado evoca cheiro, imagem e presença. Fazendo 
assim com que o espetáculo provoque uma experiência visceral, dura e ativa constantemente, não deixando o público no lugar de uma contemplação passiva. Roubine (1998) complementa a respeito da arte de Antoine: "é a arte de colocar o texto numa determinada perspectiva; dizer a respeito dele algo que ele não diz, pelo menos explicitamente; de expô-lo não mais apenas à admiração, mas também à reflexão do espectador".

Neste sentido, a peça didática de Brecht, como Koudela (2003) aponta a pedagogia de fazer o espectador ser o responsável pela escrita e direção, entre outras coisas, e isso o permite repensar, fazer de novo. O autor alemão propõe que não haja separação entre espectadores e atores; ele destaca ainda que a principal função da peça didática é a educação dos participantes por meio do ato artístico coletivo (Cf. KOUDELA, 2003, p.24).

Brecht também falava da importância do teatro emancipar seu público, e, para isso, fazê-lo presente aos efeitos cênicos escondidos outrora, era necessário a peça Luis Antonio - Gabriela, possui muito dessa característica, eles iniciam a peça, como podemos conferir no anexo deste volume, com os atores dizendo seu nome, que personagem farão e que objeto utilizarão para representar algo que venham a fazer concomitantemente com esta personagem e uma outra secundária. Assim como a peça A Vida, que já parte de um sorteio cena a cena, mostrando ao espectador que se está dentro de uma espécie de "jogo da roleta" sem cenas já determinadas para o dia da apresentação.

A respeito deste aspecto constantemente repetido acerca do desejo de causar transformação por meio do teatro, Koudela (2003) destaca uma fala importante de Heiner Müller: "Para transformar a sociedade por meio do teatro é indispensável modificar as estruturas do teatro, que são um reflexo das estruturas da sociedade". 


\title{
40 Espectador
}

Diante do grande número de espetáculos em cartaz na cidade de São Paulo, a cada ano, é pertinente conversar com os espectadores destas apresentações para conseguir uma aproximação de o que se pode entender sobre a experiência obtida por eles, ao assistirem uma obra teatral. Partindo do princípio de que apenas uma pequena parte dessa apreensão pode, de fato, dar-se em meio a uma infinidade de percepções e sensações, que não são facilmente traduzidas ou fáceis de serem identificadas e declaradas.

Vamos agora dar luz ao sentido etimológico das palavras "espectador" e "teoria", extraídos da tese de doutorado de Leonel Carneiro, intitulada A experiência do Espectador Contemporâneo: Memória, Invenção e Narrativa, (CARNEIRO, 2016), que muito parece pertinente para este estudo:

\begin{abstract}
A palavra espectador deriva do Latim Spectator, que ao mesmo tempo significa olhar e observar, mas também contemplar, aguardar. Uma outra palavra para espectador que seria a que vem do Grego Theoros ( $\theta \varepsilon \omega \rho o ́ s)$, que significa aquele que olha. Theoros era a palavra utilizada pelos gregos para designar a pessoa que era enviada para consultar um oráculo, mas também para o cidadão que era enviado pelas cidades gregas como o observador dos festivais (DAVEY, 2013). A palavra Theoros é a base da palavra teoria ( $\theta \varepsilon \omega p i ́ \alpha)$, cujo sentido seria contemplação, especulação, olhar para algo. (CARNEIRO, 2016, p.34)
\end{abstract}

É importante localizar quem é o espectador, atentar-se minimamente para quais são suas predileções, e entender ainda que os espectadores são formados geralmente por um círculo de pessoas que permeiam determinados espetáculos, de acordo com suas preferências. Muito se questiona a respeito dessa identidade do espectador, pois, cada vez mais, o que se tem nas salas de espetáculos são profissionais do teatro assistindo seus pares, e, desde a Grécia, o espectador era o cerne desta arte (CARNEIRO, 2016, p.46), o espectador da cidade, detentor de outras profissões que não ligadas à arte.

Não se pode esquecer, por mais que pareça óbvio, que é para o espectador que se faz teatro; toda ideia que se tem a transmitir acontece segundo um desejo de pensar junto, trazer reflexão. $O$ espectador é um dos componentes mais importantes 
que o teatro possui. Os artifícios cênicos são cuidadosamente colocados em cena para promover este encontro - é o espectador o personagem mais interessante do jogo teatral. Entender parte de o que acontece neste encontro e como ele se dá física e mentalmente parece uma abordagem útil para a pesquisa.

Ao analisar a obra Teoria da Escuta de Pierre Schaeffer 6 , pode-se perceber que o olhar lançado ao espectador muitas vezes é limitado, entendendo-os apenas como quem assiste ao espetáculo, e considerando predominantemente seu sentido de visão (olhar), ignorando todos os outros quatro dos que conhecemos como sentidos fundamentais - paladar, tato, olfato e audição. Segundo Marie-Madeleine Mervant-Roux ${ }^{7}$, é importante entender a plateia como grande ressonadora de o que acontece no espetáculo, e até mesmo ter a experiência de apenas ouvir as cenas, sem necessariamente vê-las. A modulação de um espetáculo é rítmica; existe uma ligação sensorial a ser considerada. Em sua teoria, Schaeffer utiliza a seguinte divisão:

\begin{abstract}
Escutar (Écouter). Prestar ouvidos, se interessar por. Eu me dirijo ativamente a alguém ou alguma coisa que me é descrito ou assinalado por um som. Escutar não é necessariamente interessarse por um som. É só se interessar por ele excepcionalmente, mas por seu intermédio, visar outra coisa.

[...] Ouvir (Ouir). Ouvir é perceber pelo ouvido. Por oposição a escutar, que corresponde à atitude mais ativa, aquilo que ouço é aquilo que me é dado na percepção.

[...] Compreender (tradução mais próxima de Entendre). Dirigir seu ouvido para, de onde, receber as impressões do som. Escutar (entendre) o ruído. Eu escuto (j'entends) falar no cômodo ao lado, eu entendo ('entends) que conta novidades. (SCHAEFFER, 1966, p.103 a 107)
\end{abstract}

O espectador tem a frente de si inúmeros dispositivos que possibilitam que

\footnotetext{
${ }^{6}$ - Pierre Schaeffer Foi um grande compositor e teórico da música, conhecido por ter inventado a música concreta.

7 - Marie-Madeleine Mervant-Roux é pesquisadora do ARIAS (THALIM) do CNRS (Centro Nacional de Pesquisa Científica, França) e professora emérita da Université Sorbonne Nouvelle - Paris III. Seus trabalhos sobre o espectador e sobre os teatros dos amadores se inscrevem em uma pesquisa sobre a função dramática na Europa. Ela coordena desde 2008, em parceria com Jean-Marc Larrue do CRlalt (Centro de Pesquisas Intermidiais em artes, letras e técnicas) de Montreal, um projeto internacional sobre "O som do teatro (séculos XIX-XXI)", cujos primeiros trabalhos foram apresentados nos números 197, 199 e 201 da revista francesa Théâtre/Public: Leson du théâtre : Le passé audible (2010-3); Dire l'acoustique (2011-1) et Voix Words, words, words (juillet-septembre 2011).
} 
muitas emoções sejam despertadas. Pode haver uma identificação originária da lembrança de algo vivido, ou deixar ressoar em seu corpo o encontro com um espetáculo, o que faz com que ele se torne inesquecível exatamente pela sensação corporal obtida. Pode-se ainda ter repulsa ou até mesmo nada afetá-lo ou modificálo, por uma proteção inconsciente do organismo, mas que faz com que, de algum modo, o registro do que foi vivido e presenciado permaneça em si.

Muitas vezes, uma companhia teatral possui, além dos espetáculos, projetos que buscam proporcionar à comunidade do entorno de onde se apresentam experiências ligadas às artes cênicas, assim como projetos vocacionais alinhados a gestões culturais, que proporcionam cursos livres de longa duração, no qual os interessados passam por toda a linha de formação de um ator, de maneira mais condensada, de modo a despertar e apresentar um pouco do mundo teatral para pessoas que, até então, não haviam tido nenhum contato com o teatro.

Com base na tese de doutorado de Carneiro, o Projeto Vocacional buscava fazer com que o aluno, depois de "formado", entrasse num processo de autoformação. É possível, portanto, relacionar essa intenção do projeto com a ideia de composição de Spinoza: o que compõe comigo? O que aumenta minha potência? Partindo do princípio de que, se o aluno se sentiu satisfeito e algo o afetou durante sua participação no curso, ele pode não só se tornar um espectador assíduo de teatro, mas também vir a se tornar um profissional desta área, a exemplo do que relata Carneiro, quando apresenta o percurso do aluno e espectador Paulo Sant'anna, em parte de uma entrevista de sua tese:

Paulo Sant' Anna - Mas é claro que depois [do espetáculo] os pensamentos vão se elaborando. Porque [O beijo no asfalto] foi um espetáculo que eu carreguei... assim, há espetáculos que você assiste que você carrega. Que ele vive em você durante muito tempo, e esse é um espetáculo que ainda vive em mim, muito! É muito presente, porque me pegou muito e me fez debruçar para tentar entender quem é aquele cara [Nelson Rodrigues]. (CARNEIRO, 2016, p.99)

Paulo Sant'anna participou do projeto de Formação de Público, em 2004. Essa entrevista aconteceu em 2012, e é evidente que depois de oito anos, essa afecção ainda é muito forte. Carneiro relata em sua tese que Paulo assistiu uma 
montagem da peça $O$ Beijo no Asfalto, de Nelson Rodrigues, indicada por seu professor do projeto, e foi pesquisar o autor por conta própria. Hoje tem um grupo no qual boa parte das pesquisas se ligam a Nelson Rodrigues.

Com base nisso e rememorando o pensamento de Marie-Madeleine MervantRoux, Paulo Sant'anna se tornou um ressonador em potencial do espetáculo que assistiu, e agora é também um disparador de "sons" no mundo, pois também se tornou um propagador das artes cênicas, proporcionando possíveis afecções por onde apresenta os trabalhos de seu grupo. Pode-se dizer ainda que Paulo - sofreu a afecção desejo, que acabou tendo despertado em si uma vontade que, de algum modo, estava em seu corpo. Ao ter tido o encontro com o espetáculo, "transbordou" para que uma formação específica fosse buscada.

Desta forma, é possível considerar também, ainda que não pretendida, a grande contribuição do trabalho de Spinoza à análise da experiência do espectador, na qual o sujeito se afeta e pode, a partir disso, privilegiar encontros que aumentem sua potência em existir, como aconteceu neste caso. Carneiro, ainda que tratando de memória, faz uma reflexão pertinente que se alia a essa pesquisa, concluindo também uma forte afetividade como dispositivo destes acontecimentos que se desencadearam após o encontro de Paulo com o espetáculo:

Mas o que faz que Paulo tenha sido movido a procurar por Nelson
Rodrigues de tal forma após assistir à peça? Ao que parece ele
mesmo dá a resposta ao dizer que gostou, se apaixonou pela obra
do dramaturgo, confirmando a hipótese de que a inscrição de uma
experiência como significativa para um espectador está ligada a uma
afetividade.
Trato mais diretamente, no caso de Paulo, dos dados trazidos por
seu discurso, mas é óbvio que pode haver outras influências na
constituição desta experiência que nem sempre são tão claras. O
teatro continua sua vida em uma relação simbiótica com seus
espectadores. A memória do evento teatral podia se manifestar de
maneira direta como narrado por Paulo ou de formas mais veladas.
(CARNEIRO, 2016, p.101)

O Projeto Vocacional é um programa que existe na cidade de São Paulo desde 2001, promove e estimula a atividade artística nas linguagens de artes integradas, artes visuais, dança, literatura, música e teatro por meio da formação e orientação de grupos e turmas, é aberto a todos os interessados maiores de 14 anos, atualmente passou por um triste desmonte e funciona apenas em algumas 
regiões e de modo precário.

Na dissertação de Morais, aparece também um participante de sua pesquisa que retrata o quão significativa foi sua experiência, a partir das práticas propostas nos encontros:

Uma proposta simples, entrevistar alguém, ouvir uma pessoa contar
sobre seus medos, suas alegrias, suas experiências de vida. Nada
mais simples do que isso. Parar e ouvir alguém. Justamente nesta
simplicidade estava, em minha opinião, o coração daquele processo
que o Hércules orientava. Em algum encontro a gente falou sobre,
espada, corte, feridas. Fui cortado. Jamais serei o mesmo depois
deste processo. Fazer as cenas como recortes da vida que nós
mesmos não paramos para observar, a experiência de ser o criador
de minha própria obra, de me sensibilizar com o cotidiano e ver ou
transformar isso em poesia, o simples e rico ato de ouvir o outro é
algo que ninguém, jamais vai me tirar, é pra toda minha vida. Já
pensou se eu tivesse desistido? (Romário Lopes - Dez.2012, p. 215,
ANEXO B)

Morais analisa então a fala de Romário, trazendo também a ideia de que o contato com a proposta relatada de alguma maneira, pôde transformar a visão do garoto de modo que ele a partir de então, diga repensar seu jeito de agir no mundo, tendo sido desperto por meio do exercício a perceber o todo a seu redor com mais sensibilidade e calma, entendendo também que as coisas podem ser mais simples do que imaginara:

Pelo relato do participante, podemos perceber o quanto a proposta artística ressignificou o olhar sobre a vida cotidiana "Fui cortado. Jamais serei o mesmo depois deste processo" (Romário Lopes, participante da pesquisa), o processo de elaboração das cenas e, sobretudo, o olhar para o mundo como material a ser pensado partilhado em um espetáculo, somam-se para que a experiência de significação pessoal do mundo possa ser mais integrativo e participativo. (MORAIS, 2017, p.79)

É importante trazer esses relatos para formar uma espécie de trama entre pesquisas paralelas a essa e que de algum modo, mesmo com diferentes focos, cada qual com uma teoria específica, ainda formam uma rede que juntas se potencializam e complementam este campo de pesquisa, a partir de diferentes investigações acerca do mesmo tema. 
É interessante perceber a maneira pela qual as pessoas relatam suas experiências, e como elas são fortes em suas trajetórias de vida, ao ponto de declararem que a partir de então, jamais terão determinada atitude como tiveram outrora. Neste momento, localiza-se um ponto de mudança, algo parece ter se instaurado e modificado uma estrutura, e isso não é facilmente nomeado, mas é vivo e está ali sublinhando um ponto de mudança.

Existem ainda algumas teorias que vão ao encontro do pensamento de Spinoza, e que contribuem com essa pesquisa. Uma delas é $A$ Pedagogia do Espectador de Flávio Desgranges, na qual se busca um experimento novo dando visualidade ao espectador. Para Desgranges, o espectador é o protagonista do teatro em seu sentido político. Ele tem, a partir disso, a possibilidade de realizar a leitura de signos, e contribuir com novas ideias não apenas socialmente, mas também em não mais dicotomizar as demandas sociais de sua vivência familiar individual, uma vez que uma coisa está intrínsicamente ligada à outra. É claro que isso ainda é um plano a ser construído, mas, de certa forma, converge muito com a ideia de Spinoza de emancipação, ainda que com uma abordagem completamente diferente, partindo deste outro viés. Desgranges fala um pouco deste olhar do espectador e uma possível maneira de interpretá-lo:

O autor da obra (ou mesmo o herói) pode ser entendido como o outro do espectador, que re-significa a realidade social, base comum a todos, possibilitando que ele (espectador) veja seu meio social (e a si mesmo) "pelos olhos dos outros" para, em seguida, regressar a consciência e elaborar esteticamente respostas que dêem uma visão do todo contido naquele olhar. O contemplador capta na obra a realidade (na qual está inserido) vista pelos olhos do autor e, posteriormente, retorna a si para o "acontecimento último", a concepção refletida de um juízo de valor acerca da obra. (DESGRANGES, 2010, p.127)

Pode-se dizer que, para além de um juízo de valor, a partir deste duplo pensamento entre a obra e o sujeito que a assiste, existe um despertar no qual, anteriormente, o meio televisivo - por uma marca de caráter rotineiro - não consegue atingir, pensando aqui que o espectador possui muito mais chances de estar habituado à televisão, devido a sua facilidade de acesso, do que ao teatro, que dele exige um certo esforço de locomoção, compra de ingresso e até mesmo de atenção. 
É a linguagem teatral que, em certa medida, tem chance de envolver o espectador, proporcionando-lhe uma nova sensação devido as suas possibilidades de montagens e abordagens diversas.

A partir disso, o espectador pode então, caso se identifique positivamente com este novo encontro (espetáculo teatral) em seu percurso de vida, passar a ter o hábito não só de ir ao teatro, mas de fato estender seus pensamentos de comparação e reflexão das coisas que acontecem a seu redor, dando a si próprio um novo percurso para lidar com os fatos cotidianos que nos acometem com mais alteridade, uma vez que ele conseguiu essa relação com uma obra teatral. 


\section{Os Espetáculos}

Faz-se necessário, para um entendimento mais amplo acerca das falas dos espectadores que virá a seguir, uma sucinta explanação a respeito dos espetáculos pesquisados. Ambos os espetáculos possuem uma característica documental muito forte, são feitos a partir de relatos pessoais e da sensibilização artística dos atores para as criações cênicas. Este não foi um fator inicialmente premeditado neste estudo, mas, em uma sequência natural na seleção dos espetáculos trabalhados, foi interessante poder condensar dois espetáculos diferentes em suas linguagens, mas dentro de um mesmo gênero e ainda com a direção assinada pela mesma pessoa: Nelson Baskerville.

É importante ressaltar também que os dois espetáculos possuem imagens muito fortes, com a certeza de que não é possível descrever exatamente o que acontece quando estamos frente a essas cenas. Farei aqui um exercício de descrever algumas delas, pois são imagens que trazem horror, causam uma ruptura no que se estava vendo anteriormente, desconcerta, cria um clima de suspensão nos espectadores.

Em Luis Antonio-Gabriela, há um momento em que Gabriela está no Museu Guggenheim em Bilbao com sua irmã que a está visitando e cuidando por alguns dias; de repente, a irmã percebe que Gabriela defecou em toda a sua roupa, a irmã tenta disfarçar movendo-se de um lado pro outro desesperada, segura Gabriela pelo braço, e pergunta o porquê de ela haver mentido que tinha colocado a fralda. $\mathrm{O}$ som mais alto vai tomando a cena, as obras que foram expostas desfiguradas para representar a sala do museu no cenário vão ganhando mais luz; e Gabriela, chorando, também desesperada, diz que mentiu e não colocou a fralda porque a fralda ficava a vista em sua roupa, a personagem na peça começa a gritar: "Porque a fralda marca Bicha! A fralda marca!".

Existe neste momento uma profunda comoção, pois Gabriela, que está com um quadro de saúde absolutamente fragilizado por conta de enxertos feitos com silicone industrial em seu corpo para criar volumes femininos de seios, coxas e nádegas, tudo visualmente deteriorando, está ali sofrendo em um espaço público mais uma situação humilhante.

Do mesmo modo no espetáculo $A$ Vida, existe uma cena na qual a atriz Tamirys relata um abuso sexual cometido por um garoto que chega em sua casa 
ainda na adolescência para um encontro a tarde, e ao perceber que estão sozinhos, força a garota a deixar que ele introduza violentamente alguns dedos em sua vagina. O espectador junto com ela vai se movendo na cadeira e mudando o semblante temendo o que acontecerá no segundo seguinte, quanto então a atriz dá um grito de dor que ecoa por todo o espaço.

A atriz não está num cenário que aparente a casa, ela abre supostamente a porta ao menino, sobre escadas de ferro absolutamente não pensadas como cenário no sentido realista, e se senta numa cadeira alta como a de um bombeiro nas praias, por exemplo. E é assim que o espectador é tomado por um terrível assombro, por uma dor e um susto que incomodam por dias a fio, para não dizer talvez que eternamente, após sair do teatro.

Essas cenas completas e as demais poderão ser lidas no anexo desta pesquisa caso haja curiosidade.

\section{1 - Luís Antonio-Gabriela}

Realizado pela Cia. Mungunzá de Teatro, este espetáculo foi o grande disparador de minha ideia de pesquisa. Foi, por meio dele, que, ao me ver absolutamente envolvida, senti o desejo de pesquisar os motivos que podem levar um sujeito a se afetar tão intensamente com uma obra, a ponto de sair soluçando do teatro, e tê-lo no pensamento com nitidez tamanha que algumas das falas dos atores, anos depois, ainda permaneçam na memória.

Isso ainda pode parecer um motivo muito simples para desencadear uma dissertação de mestrado, mas justifico ainda, que meu desejo de pesquisa se intensificou ao longo das temporadas deste espetáculo, assistidas por mim diversas vezes. 


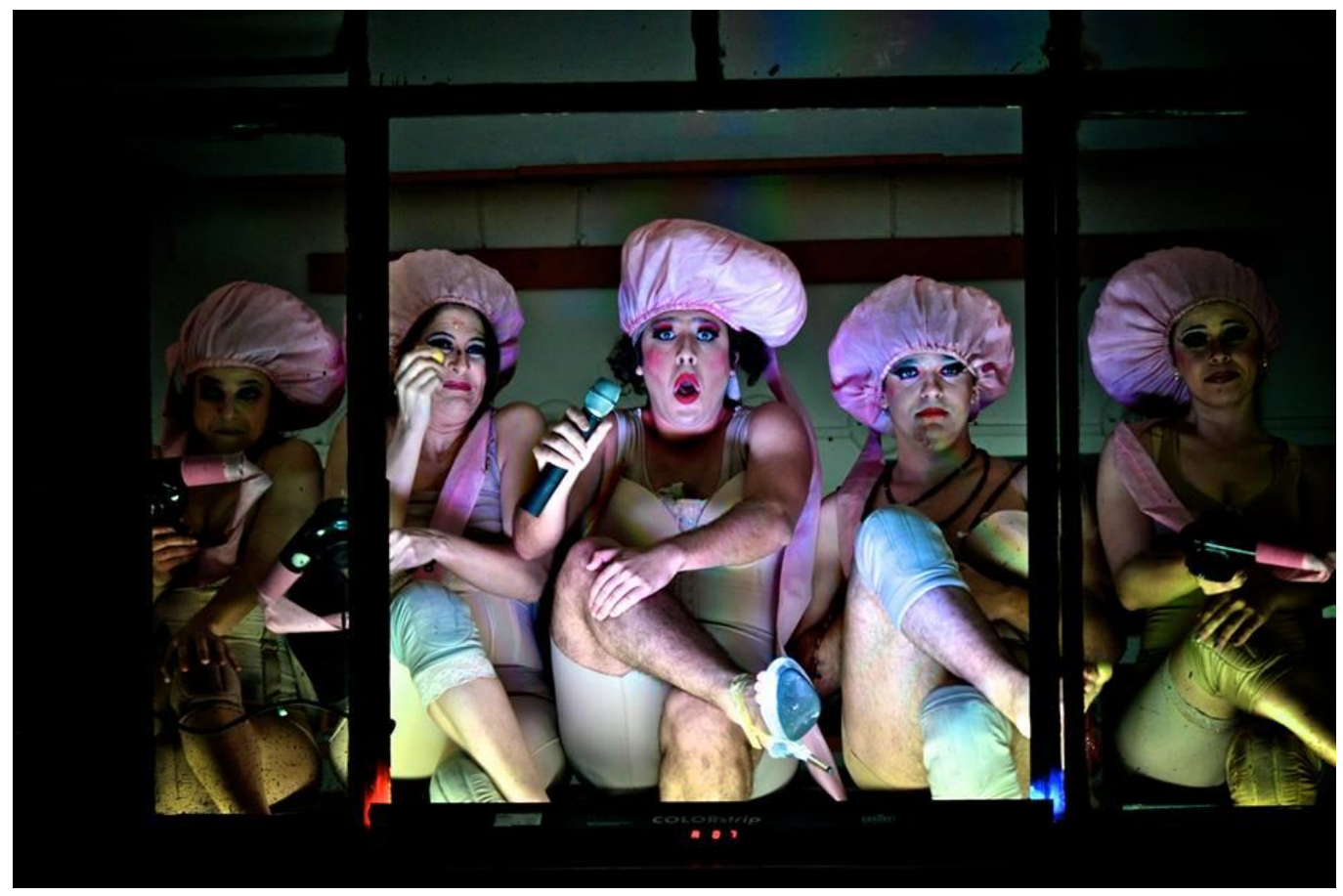

Figura 1: Cena da peça Luis Antonio-Gabriela. Foto: Bob Sousa

Após perceber que o restante dos espectadores tinham uma ligação com essa peça como raramente presencio nos teatros, ao ver que não foi um fator individual, uma sensação particular, mas que isso se propagava em todos os demais estados e municípios que o grupo percorria, fazendo com que os espectadores escrevessem nos cenários suas impressões e sensações assim que o espetáculo acabasse oferecido ao público por uma iniciativa do grupo, de maneira muito intensa e espontânea como poderemos analisar adiante.

Luís Antonio-Gabriela é um espetáculo feito a partir do relato de Nelson Baskerville (diretor do espetáculo), a respeito de sua vida familiar desde a infância. $O$ fator principal que aproximou sua fala para a realização de um espetáculo foi o fato de ter tido um irmã mais velha transsexual, atualmente falecida, e ter percebido, refletindo a respeito dos diversos casos homofóbicos ocorridos e conhecidos a nível nacional, como o ataque a um jovem gay com uma lâmpada fluorescente na Avenida Paulista em São Paulo, como era urgente que o assunto fosse abordado. Não apenas como um movimento político para debater questões importantes socialmente, como costuma acontecer no teatro, mas também para rememorar seu caso familiar, e questionar o fato de que se muitas vezes não é possível acolher uma situação diferente nem mesmo dentro de casa, o que dizer de pessoas externas que 
possuem o preconceito fomentado por conta de análises rasas de fatos muito isolados. Nas palavras dele, a necessidade deste espetáculo:

Eu estava morando no Rio, fazendo novela, e minha irmã foi passar o reveillon comigo lá, isso foi em 2010 e pela primeira vez, a gente sentou e eu perguntei o que tinha acontecido nessa viagem dela de Bilbao, porque até então, a gente tinha falado muito superfluamente sobre a viagem, sobre o Luís Antonio, sobre a morte dele, a gente não... (pausa) ninguém falava no assunto, ninguém tocava no assunto, e também junto disso, teve aquele ataque na Paulista que os carinhas atacaram um gay com uma lâmpada de mercúrio, e aquilo, é... foi como assim, se eu tivesse sido agredido, e eu comecei a pensar, o que levava alguém a uma agressão, e aí também pra ir pra uma associação da agressão que a minha irmã tinha sofrido, a Gabriela, Luís Antônio, ai foi muito... falei porra, a gente tem uma história que é totalmente de preconceito, de não saber lidar, então, se nós que tivemos um irmão nessas condições não soubemos lidar, imagina alguém que só escuta as bobagens e os folclores sobre isso, então foi quase como, veio quase como uma obrigação pra mim, eu não poderia falar de outra coisa naquele momento que não fosse aquilo, e aí eu propus pra eles (Cia. Mungunzá), eles toparam e ai fizemos e ai foi indo... ${ }^{8}$

De algum modo, segundo a teoria de Spinoza, é possível conectar uma primeira afecção de Nelson com a notícia da violência ocorrida na Avenida Paulista, que possui uma ligação com a afecção-paixão tristeza, que o remete imediatamente a seu percurso de vida com sua irmã, e isso o afeta com se fosse ele o agredido. Isso poderia diminuir sua potência, e o deixar melancólico ou outra sensação possível, mas somada à afecção-paixão desejo, essa dupla afecção o fez analisar

\footnotetext{
8 - Esta entrevista aconteceu em São Paulo, na residência de Baskerville, em 27 de Agosto de 2017.
} 
não apenas sua vida familiar, mas ainda o que leva alguém a tomar uma atitude como essa na rua contra um estranho. Baskerville levou sua expressão artística à última potência, e fez disso um espetáculo inesquecível para a grande maioria de seus espectadores, em parceria com a Companhia Mungunzá.

Baskerville relata ainda que o espetáculo foi um primeiro desengate para seu processo de autoconhecimento, pois foi nesse "pedido de desculpas" (frase final do espetáculo que roda num display) que muitas fissuras a serem trabalhadas se mostraram, não o salvando dos problemas, mas o solicitando em certa medida que fossem trabalhados, concluindo assim um grande processo de mudança em prol de sua maior liberdade nos termos de Spinoza: a liberdade que o permite se sentir feliz consigo, que não o torna um sujeito escravo de uma paixão, mas que lhe permite fugir sempre da comodidade de uma vida estável e rotineira.

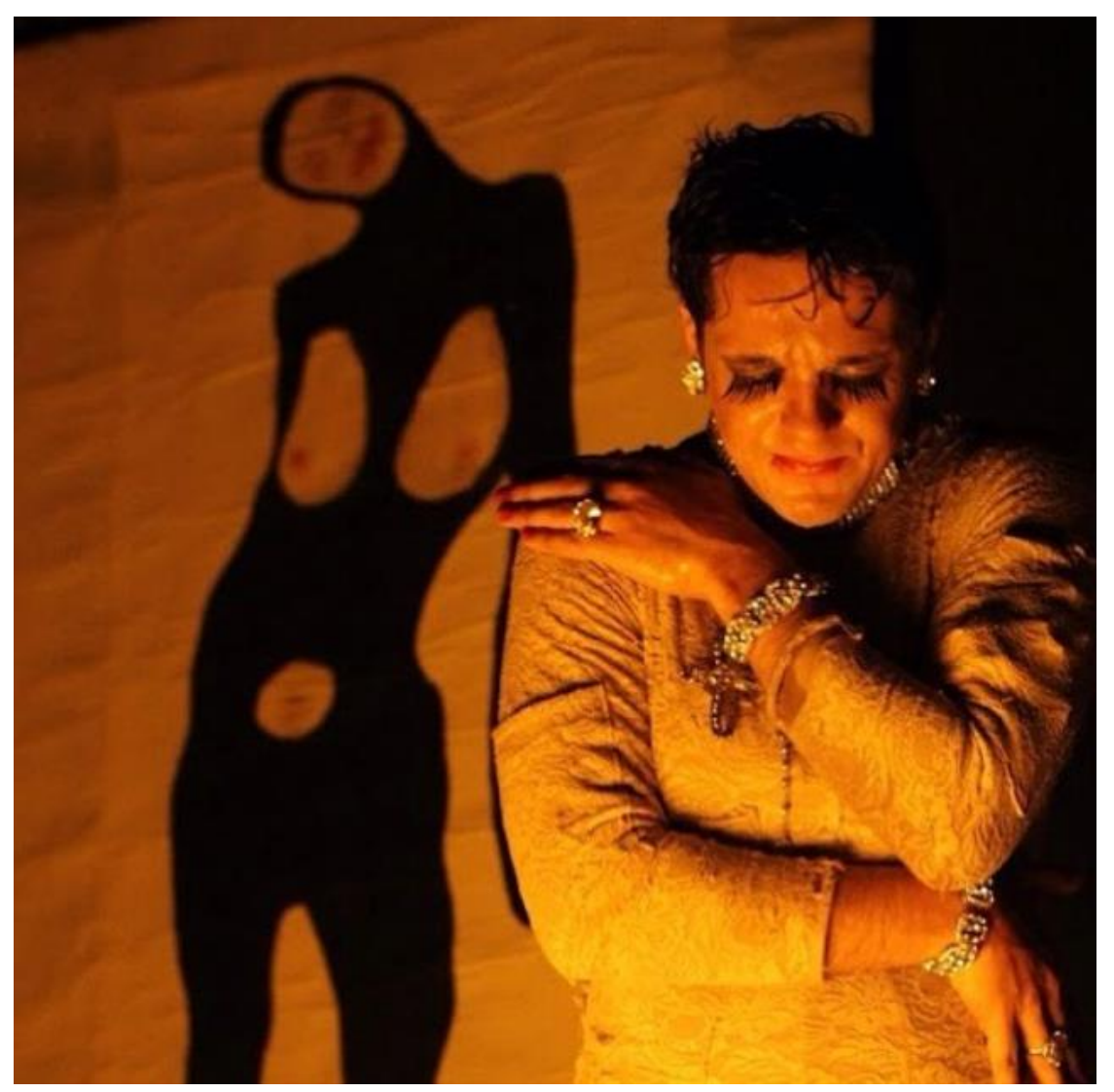

Figura 2: Cena da peça Luis Antonio-Gabriela. São Paulo, 2016. Foto: Ligia Jardim. 
A atriz Verônica Lo Turco Gentilin (Cia. Mungunzá) relata que o espetáculo foi criado dançando, faziam um trabalho muito forte de corpo que acabava por desenvolver numa experimentação criativa. É desse percurso que surge que depois virou cena. Os estudos de mesa ${ }^{9}$ eram muito raros. Desta forma orgânica, deram-se as identificações com as personagens, e foram experimentando a partir deles, cada ator com o seu. Verônica também partilhou um pouco sua hipótese do motivo da afecção de tantos espectadores:

A minha opinião particular é de que um dos motivos de grande afecção deste espetáculo é porque salvo dois textos que eu escrevi que são ficcionais, $99 \%$ do espetáculo foi dito por pessoas reais, e a gente não mudou nada, a gente só reduziu, então o que é dito saiu da boca da Doraci, do Serginho, a gente não mudou uma vírgula, a gente só editou no sentido de reduzir. Então, por isso é que é um texto muito humano, por isso não é um texto que dá um sentido, que dá uma lição de moral, ou que faz uma reflexão pós algum evento, ele é um durante porque as pessoas estão contando de uma forma, como elas estavam inseridas. As pessoas que contaram sobre essa história não foram pessoas que estudaram essa história, foram pessoas que viveram, então eu acho que por isso elas se identificam muito com esses personagens, porque eles são reais, e o texto todo saiu da boca deles. ${ }^{10}$

A hipótese de Verônica converge muito para as noções de afecção dada por Spinoza, pois são fatos cotidianos e diários que afetam um sujeito o tempo todo. Todos os seres existentes na natureza, que é Deus para Spinoza, estão sofrendo encontros dos mais diversos para continuarem a perserverar em seus seres. Deste modo, o encontro do espectador com este corpo-espetáculo, que não é artificioso,

\footnotetext{
9 - Estudos de mesa são estudos feitos pelos grupos de teatro, normalmente no ínicio dos processos de montagem, no qual os atores estudam o texto e possíveis referenciais teóricos e discutem entre si para determinar o tipo de montagem e encenação.

10 - Esta entrevista aconteceu na sede da Cia Mungunzá de Teatro em São Paulo, em 13 de Setembro de 2017.
} 
mas que trata da vida real, pode ser um grande canalisador das afecções que estão dentro dos sujeitos, e obtém por meio das cenas uma identificação tal como uma espécie de reflexo. Baskerville, que teve Fauzi Arap como professor, diz ter levado para sempre a frase que seu mestre dizia consigo: "O palco não suporta mentiras"; a vida já possui fatos suficientemente importantes e dramatúrgicos para que grandes invenções sejam feitas, o que pode levar inclusive ao não convecimento e, por consequência, possivelmente pouca afecção.

O ator Marcos Felipe (Cia Mungunzá) relata um pouco de como foi o processo de construção do espetáculo por parte do elenco:

A gente trabalha muito pouco com construção de personagem, a gente trabalha o ator em ação, o ator em situação, isso exige da gente sempre um aperfeiçoamento em estar com os poros abertos pra sensibilidade, para o que está acontecendo na hora, e para o que esta acontecendo no texto, então a forma com que a gente trabalha o texto passa pela gente, e eu só preciso estar sensível ao texto, então se eu estou sensível e aberto ao texto, logo toda a emoção, todos os trejeitos, tudo vai reverberar em meu corpo e em minha fala, então é o contrário, eu não faço uma construção e a partir desta construção eu dou o texto, eu me mantenho sensível para o texto me atravessar, a partir do momento que o texto me atravessa, meu jeito de falar vai ser outro, meu olhar vai ser outro, o jeito de atuar vai ser outro, eu só preciso estar sensível pro texto me atravessar. A dificuldade talvez seja maior do que a de construção de personagem, porque é muito difícil você se manter sensível aos problemas, as questões, é muito difícil, é isso, é você dar um texto e estar sensível ao que você está falando, isso você carrega da vida, das suas relações afetivas diárias... ${ }^{11}$

11 - Esta entrevista aconteceu na sede da Cia Mungunzá de Teatro em São Paulo, em 13 de Setembro de 2017. 
Este trabalho ao qual Marcos se refere, lembra o modo de trabalho do Lume Teatro. Ainda que o trabalho de corpo desenvolvido seja diferente, existe uma similaridade, e é interessante perceber como um certo sinal de potência surge de trabalhos que lidam incessantemente com o corpo em plano principal. Não são trabalhos feitos com frequência pela maioria dos grupos teatrais. É, inclusive, muito raro que uma experiência chegue a se tornar significativa para o espectador. Muitas vezes, têm-se um espetáculo com excelência em vários aspectos, mas, por alguma falta de intensidade ou potência, ele não afeta o público, Ferracini faz essa conexão a respeito do trabalho de ator muito próxima com a fala de Marcos, e conecta isso a uma ideia de potência:

A potência de existência do corpo relaciona-se mesmo em seu estado cotidiano de existência - mais com o poder de compor com as forças externas para ampliar sua potência do que pela sua capacidade de agir. De fato é essa composição que amplia sua potência de ação. No corpo assim como na matriz poética, o agir se produz pelo afeto e por essa capacidade de composição. A preparação do ator deveria focar seu trabalho muito mais em sua capacidade de compor com as forças e linhas que o atravessam para daí gerar ação do que em uma capacidade de agir tecnicamente e de forma somente precisa pelo tempo-espaço... Esse poder de composição também não deve ser confundido com causa-efeito: o atuador não se afeta para depois agir. Ele, em realidade, age com o afeto, no afeto, pelo afeto. Compõe, negocia com o meio e age com ele, e nesse processo transforma-se e transforma. (FERRACINI, 2013, p.118)

São essas possíveis características geradoras de uma obra feita de maneira intensa, e com uma intenção de sentido pleno por aquele que a pratica, que pode possibilitar uma relação de afeto no seu encontro com o espectador, em uma mútua construção da representação, tornando-a mais simples e principalmente menos dependente de elementos artificiosos. 
O corpo de um ator é parte fundamental de sua exposição pública. Tornar esta atuação sensorialmente interessante e tonificada passa a ser parte de uma ação efetiva completa que se dá por meio de uma prática não apenas física, mas teórica e psicológica, práticas que vão de palestras entre os grupos que retratam o tema escolhido para o trabalho até pesquisas de campo e treinos físicos direcionados. Segundo Gilles Deleuze, quando um corpo visível enfrenta, como um lutador, as potências do invisível, ele lhes dá sua visibilidade... é como se a partir disso um combate se tornasse possível (Cf. DELEUZE, 2007, p.67). Com base nisso pode-se pensar que, para além de estabelecer uma conexão entre palco e plateia, a potência preenche também o espaço, e pode fornecer condições de sentirmos algo que momentaneamente ganha força e conecta o público ao espaço, de maneira que sua percepção se dilate por alguns instantes, e o faça ao menos sentir-se diferente por um curto período de tempo, que pode ser registrado em si como uma chave de mudança ou não. Para Spinoza, a natureza é a virtude dos afetos, estamos sempre enredados por possibilidades muitas de afecções que são naturais ao mundo, os afetos se dão por uma memória do corpo que é ativada gerando aproximação ou repulsa.

A peça pode ser conferida na íntegra por meio do link abaixo ${ }^{12}$ se digitado na internet na página do youtube, esse link tem por finalidade satisfazer uma possível curiosidade do leitor a respeito do espetáculo, mas obviamente não fornece a sensação real de presenciá-lo.

\section{2 - A Vida}

O espetáculo A Vida é composto por um grande jogo: são 34 cenas; sete delas são cenas fixas de passagem, as demais se dão por oito sorteios. Deste modo, apenas quinze cenas são apresentadas em cada noite de espetáculo. Assim, o público nunca verá todo o repertório existente em uma única visita ao teatro. A cada apresentação, o espetáculo pode ter, de acordo com o sorteio das cenas, uma versão completamente diferente.

Os temas das cenas são acontecimentos que os atores individualmente

\footnotetext{
12 - https://www.youtube.com/watch?v=q5uld7gg0RM\&feature=youtu.be
} 
partilharam a respeito de suas vidas. Fatos reais que Ihes impactaram, e que, de algum modo, precisavam ser passados adiante para além de seus corpos, vindo então à cena e por meio disso, suscitando muitas afecções em espectadores com casos familiares e pessoais muito próximos aos apresentados pelos atores, como veremos adiante.

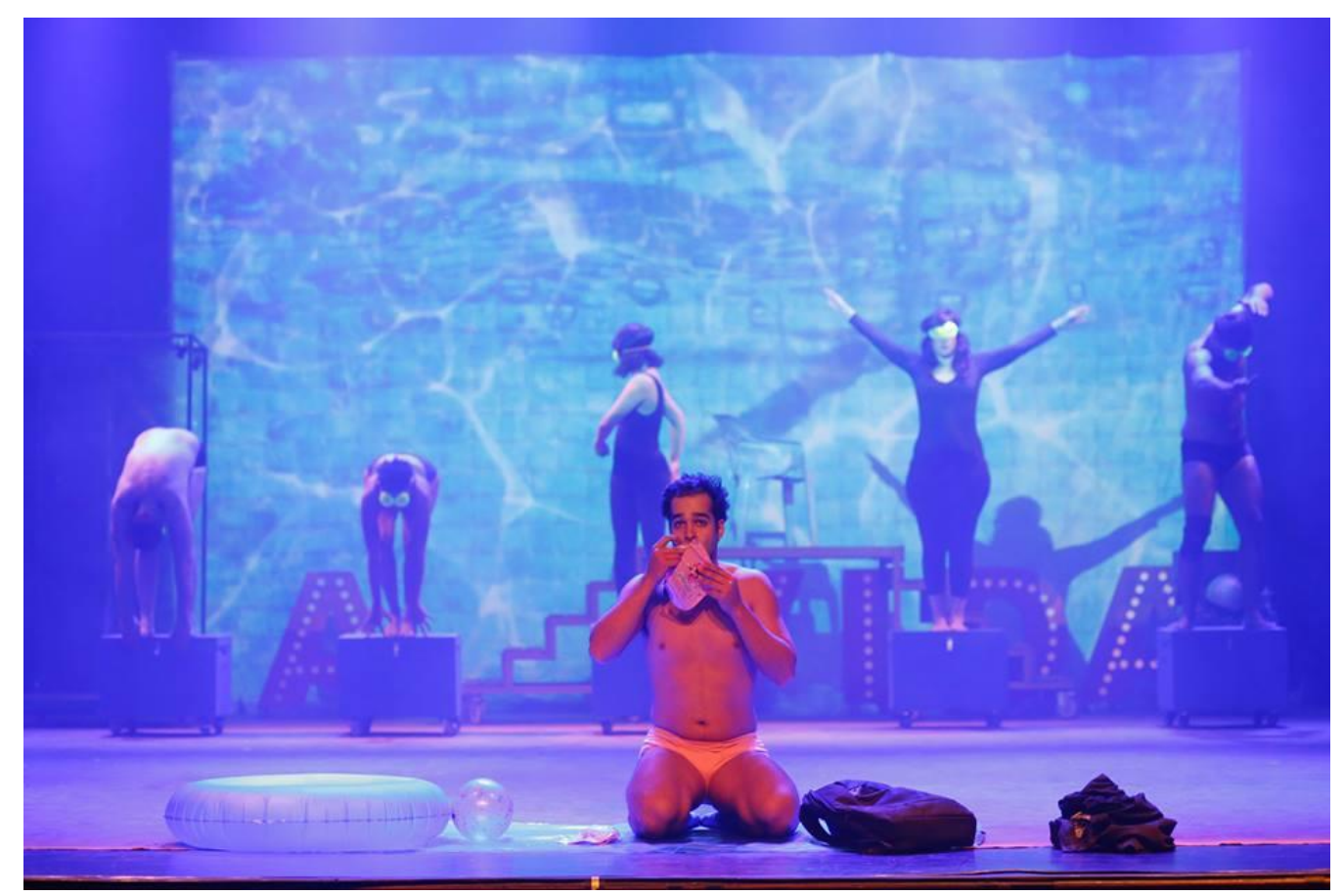

Figura 3: Cena da peça "A Vida", TUSP, 2017, São Paulo. Foto: Ligia Jardim.

Baskerville possui uma linha estética de direção muito própria, a assinatura de seu trabalho é evidente quando vemos mais de um espetáculo de seu repertório. Como ele costuma dizer, mostra a engrenagem dos espetáculos, muitas vezes a escolha da linguagem épica em seus trabalhos deriva disso, pois existe sempre um vestígio do processo do espetáculo que está em cena, as coisas não estão perfeitamente alocadas visando uma organização precisa, as fases de composição da montagem estão sempre frente ao público atreladas e expostas em seu resultado.

Em entrevista para esta pesquisa, ele comentou um pouco de sua construção enquanto diretor usando como exemplo a obra A Catástrofe do Sucesso de Tenesee Williams, na qual a personagem ganha muito dinheiro e vai morar num hotel de luxo; observa, em dado momento, uma pessoa limpando o lixo que produziu, e fica então comovido, por achar que ninguém deva limpar o lixo de ninguém. Baskerville diz que 
os espetáculos dele estão mostrando quem limpa essa sujeira. As personagens são as pessoas que, de alguma forma, limpam, as minorias, aqueles que estão sempre em menor ou nenhum destaque. Fala também de seu caráter democrático enquanto diretor: numa época em que o teatro essencial e a limpeza do espaço cênico são escolhas recomendadas e apreciadas por parecer uma estética mais eficaz, ele vai de encontro a essas orientações, e permite ao espectador um espaço que propicia a reflexão e o envolvimento concreto com o que acontece a sua frente:

Não é fácil para a plateia também. Porque é muito fácil você sentar ali e ver um dramazinho bonitinho, aquela luz perfeita, e que você vai pra casa e aquilo ali sai no xixi, o espetáculo, isso é fácil. Agora, você vê uma coisa, que você vê que o cara (ator) tem que se esforçar, pra acender a lâmpada na hora certa, que tem uma hora que ele tem que arrastar móvel, que é ele que tá fazendo, eu acho maravilhoso isso.

Eu acho bonito o acúmulo de informação que tem aqui, primeiro eu estou sendo democrático, porque não exijo que o público olhe onde eu quero que ele olhe, eu dou uma visão geral das coisas, e geralmente tem mais coisas acontecendo ao mesmo tempo, o espectador é o agente editor das peças... Eu acho que essa é uma experiência que enriquece, você preencher a tua visão com uma coisa que só o homem de hoje está acostumado,que é esse acúmulo de informação, com essa poluição visual, sonora, eu acho que hoje o silêncio é quase insuportável, e a limpeza é quase insuportável, então eu trabalho com esse acúmulo de informação, não é excesso, é acúmulo, a grande descoberta de $A$ Vida, o espetáculo...é que a cada sorteio, a gente limpava a cena pra começar de novo, isso era um erro, porque você armava uma coisa e você caia...A Vida tem uma evolução na linguagem e no tipo de trabalho que eu faço, que eu nem sei onde é a direção disso, que o ator não tem o lugar fixo pra fazer a cena, o seu colega pode estar na sua frente, atrás de você... o que te obriga, a todo dia olhar exatamente pra quem você está falando...não é 
fixo nunca e não deixa também o ator se engessar, é igual a vida, a cada segundo você está tomando uma decisão.

A ideia de não adotar marcas precisas de atuação no palco, a que se refere Baskerville, é interessante do ponto de vista da afecção, pois isso permite não apenas que o ator esteja com seu sentido de atenção desperto, mas também que ele esteja sensível a perceber o que de fato vem ao encontro dele no espetáculo: o olhar atento ao colega que está em cena, as contrarregragens necessárias e os tempos delas. Até mesmo a relação com o espectador dá-se de uma forma mais consciente, pois, ao convidá-los para girar a roleta, por exemplo, existe um tempo e um cuidado a ser considerado, quando o ator toma o espectador pela mão, levemente, trava com ele uma parceria que visa confiança e respeito ao tempo daquele que não é o ator treinado para uma ação pública, mas que se dispõe a isso por estar envolvido.

Tornar o público um agente editor do espetáculo converge com o sentido que Desgranges traz em sua obra, pois isso valoriza a partipação do público, dá a ele uma importância que remonta ao início do teatro na Grécia, ao público que chegava no teatro para ser surpreendido. E por que não afetado? Entende-se a diferença entre o espectador que anteriormente já conhecia as dramaturgias, e isso possui também outro grau de ligação com o que se vê, mas isso não modifica o sentido de um espectador estar sensível e poroso a sofrer afecções.

É claro que, em todo espetáculo, o espectador não deixa de ser um editor, mas trazer esse desejo à cena, como propõe Baskerville, faz com que elementos múltiplos sejam pensados funcionalmente para isso, proporcionar diversos cortes e sequências, assim como deixar em suspensão ou até mesmo replicar cenas ou frases.

O que Baskerville propõe atrelado ao pensamento de Celso Favaretto em relação a $A$ Pedagogia do Espectador de Desgranges é: "objetivar a transformação dos espectadores em ativos decifradores dos signos da vida inscritos pelo teatro". É interessante inclusive que as cenas se dêem de forma descontinua no pensamento do público, devido ao acúmulo de informações. Baskerville acredita que isso seja uma das coisas que suscita reflexões a respeito dos espetáculos.

A atriz Thaís Medeiros (Antikatártika Teatral) relata que o espetáculo $A$ Vida surgiu de um desejo dos atores de se aproximarem de suas próprias histórias. A 
princípio, Baskerville desejava apresentar um pouco mais de sua trajetória, para além do que houvera sido exposto em Luís Antonio-Gabriela com a Cia. Mungunzá, até que percebeu, em seus encontros, que o elenco também possuia questões a serem visitadas e revisitadas, e que essa mistura dos percursos de vida de cada um podia ser algo que, naquele momento, fizesse sentido. Os atores desejavam aproximar-se de uma verdade e honestidade, em um momento que era propício olhar para as imperfeições e fissuras.

No começo, o grupo estava sentindo certa pressão em tempos pré-golpe ${ }^{13}$, atropelados por toda a movimentação política contrária à cultura que estava - e ainda está passando pelo país, na qual os artistas e todas as demais minorias se sentiam e ainda se sentem acoadas. O projeto escrito para ser apresentado ao edital Programa de Ação Cultural (PROAC) tinha uma ideia de sobrevivência considerando este cenário. Era uma oportunidade de trabalho importante. Em face de todas as justificativas exigidas no regulamento do edital, o grupo trabalhou com algumas premissas: haveria um aprofundamento vertical nos casos, combinou-se que não haveria concessões no trabalho com as explorações cênicas, e que os cenários e objetos do acervo do grupo seriam reaproveitados quase que por completo, pois, de algum modo, este espaço do grupo também viria com sua memória. Havia também uma preocupação com a memória afetiva do espetáculo.

O processo após o grupo ter sido contemplado com o edital iniciou-se com jantares entre o elenco, nos quais, individualmente, levavam receitas e partilhavam a partir disso o que aquela receita trazia de fato em si. Os relatos traziam informações como: quem foi a pessoa que ensinou, como era feita, o que aquele prato fazia lembrar, o que o cheiro trazia, entre outras coisas. E, partindo dessas questões, o grupo partilhava suas lembranças e memórias. Grande parte dessas memórias se transformou nas cenas que estão hoje no espetáculo.

\footnotetext{
13 - Período referente ao segundo semestre de 2015, em que a Presidenta Dilma Rousseff passou a sofrer fortes ataques midiáticos, liderados também por grandes empresas que visavam, por interesses próprios, um impeachment.
} 


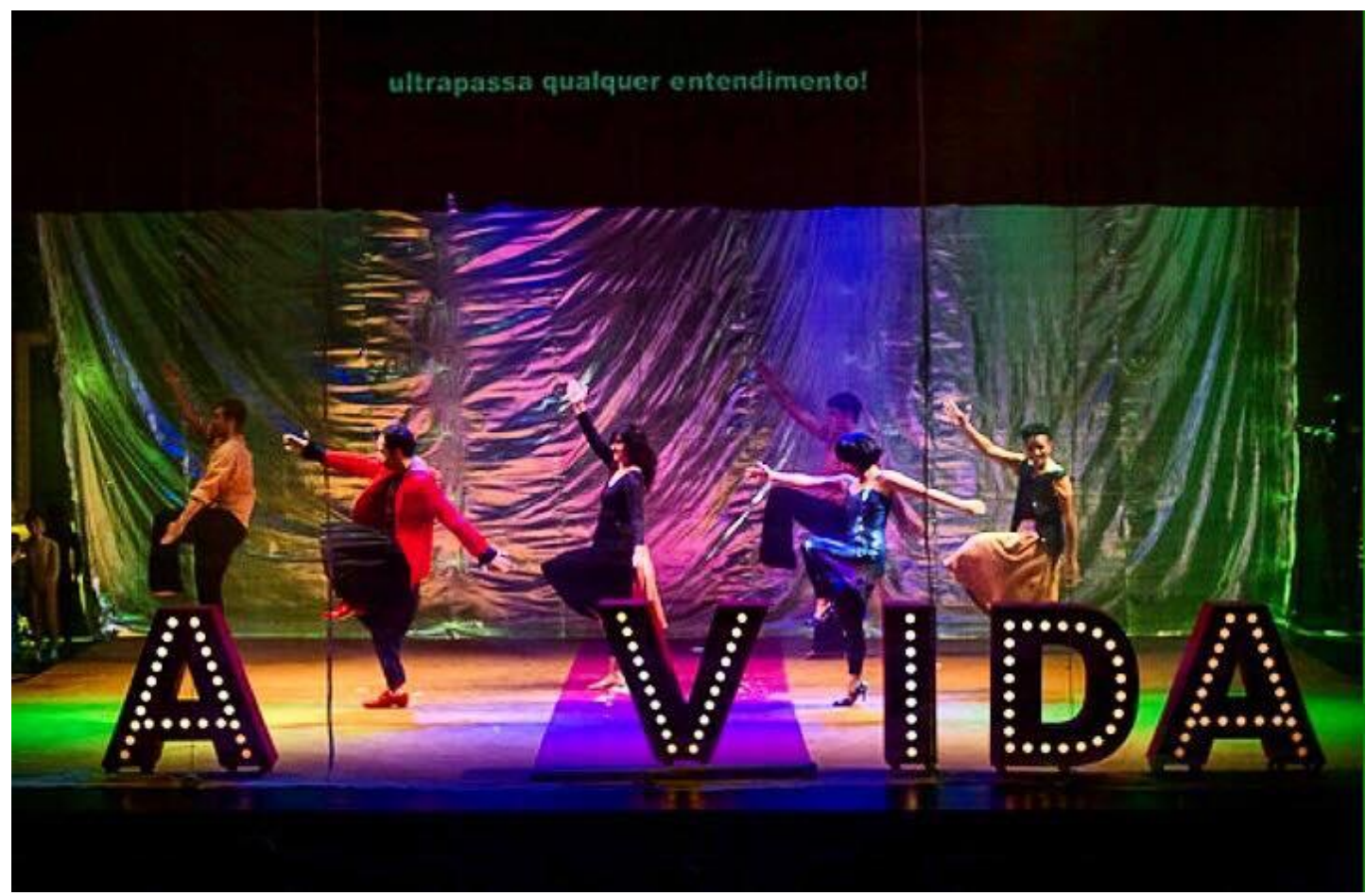

Figura 4: Cena da peça "A Vida", TUSP, São Paulo 2017. Arquivo Antikatártika Teatral.

Thaís menciona que o formato de jogo para a escolha das cenas deu-se para que o elenco estivesse o tempo inteiro desarmado, não pronto para o que viria adiante, com o intuito de buscar um lugar muito honesto e verdadeiro.

A atriz Camila Raffanti (Antikatártica Teatral) fala um pouco a respeito das intenções iniciais do grupo de passar pela filosofia, para adensarem o trabalho, e, de algum modo, refutar isso em pról do campo de trabalho das emoções:

Todo mundo tinha um pacto, um interesse pela franqueza, que isso fosse franco, e, pra achar isso, nosso norte acabou sendo muito mais o teatro do que a filosofia (como a gente achava inicialmente), porque pra essa verdade emocional ser contada da melhor forma, o teatro é a melhor ferramenta que a gente tinha, porque passava obrigatoriamente pela dramaturgia, pela linguagem do corpo, pelos significados simbólicos, para colocar aquilo no palco. Então, esse foi nosso norte, e foi muito bom, não que a gente tenha abandonado a teoria, mas ela ficava pequena perto do que a gente precisava alcançar, porque a 
gente estava falando de uma verdade subjetiva. A gente tava falando de histórias que passavam por coisas muito pequenas, de um sentimento muito específico, e, as vezes, a filosofia fazia aquilo ficar impalpável sabe...como teatro, como história, então o teatro foi o nosso grande aliado nesse processo de juntar biografia. $^{14}$

De algum modo, essa pesquisa também se dá a partir do desejo de unir a filosofia ao teatro, essa arte chamada de artes cênicas, que sempre foi a junção de muitas práticas artísticas, tais como o circo, a música e a dança. Aqui, é atrelada também ao pensamento filosófico, que muito diz do comportamento humano e da própria produção de pensamento que é exaustivamente cuidada na criação teatral, tanto pelo dramaturgo quanto por todos os demais integrantes de um projeto em montagem.

Para um estudo a respeito da afecção do espectador frente a um espetáculo teatral, no qual todas as partes envolvidas são escutadas, não parece coerente que se estude $o$ ator calcado apenas nas bibliografias de formação em arte dramática, e, menos ainda, baseando-se apenas em teorias filosóficas. Ainda que ambas sejam um ponto de estudo inicial fértil para este recorte, existe a necessidade de olhar para a cena, para os pensamentos que a compõem, e, a partir de então, ao escutar o espectador, formar uma cartografia destes encontros. Thaís traz um pensamento interessante a respeito das afecções levadas para a cena e o olhar do grupo para os materiais recolhidos:

Em vários momentos, nós começamos a entrar em embates ideológicos, por exemplo, essas questões das cenas femininas, quando a gente começou a entrar nesse assunto, que de alguma forma está muito vivo, houve essa necessidade de trazer materiais que questionam esse lugar da mulher, e que apontam questões de experiências que hoje a gente consegue

14 - Esta entrevista aconteceu no Teatro da USP (TUSP), em São Paulo, momentos antes do espetáculo A Vida em temporada lá, em 16 de Setembro de 2017. 
entender, até por conta do que a gente tem aprendido com o feminismo, isso foi muito vivo no processo, gerou muitos embates entre a gente no processo, a necessidade de arrumar um espaço para relatar essa experiência, a importância disso estar numa peça chamada $A$ Vida no momento atual.

Acho que também o espetáculo acabou sendo resultado muito dessa fricção entre todo mundo, de ideologias, pensamentos e de pontos de vista, que acho que a coisa boa é que a gente conseguiu dar vasão a muitas inquietações.

No final, muitas pessoas falam "nossa, mas não é duro você lembrar uma história que assim..." (Thaís tem uma cena que relata um abuso sexual sofrido por ela); é, é duro, é muito duro, mas é melhor eu poder falar para as pessoas, e, de alguma forma, poder me comunicar e encontrar outros pontos de vista ali e reverberar, do que eu ficar guardando isso só pra mim, e vir aqui e fazer uma coisa que não tem nada a ver com nada. Não julgando o teatro, mas esse trabalho que me dá a oportunidade de falar isso, eu considero uma sorte, eu não acho um fardo eu poder falar das minhas dores, eu acho que esse processo me cura, e a gente tem percebido aqui, que cura a quem vê também, não porque a gente tem o poder de cura, mas é que falar e pensar pode ajudar as pessoas.

Neste caso, essa síntese que resulta em uma possibilidade de cura aos espectadores, na teoria de Spinoza, está ligada a afecção-paixão tristeza, mas que necessariamente não torna os sujeitos seres melancólicos, o que poderia ser uma opção dentro deste quadro para o filósofo, mas que de algum modo contrariamente, faz com que as pessoas reflitam acerca de seus comportamentos e atitudes diante dos fatos que Ihes aconteceram, e encarem isso como algo infelizmente passível da vida, e seja apenas um fato a mais diante de todo o percurso que se possui à frente.

A atriz Tamirys O'hanna (Antikatártika Teatral) relata que tratar os momentos tristes não era a ideia principal, mas acabou por se dar em consequência, pois os fatos tristes muitas vezes podem fazer o sujeito progredir: "tem um momento que 
tem uma virada, que a gente consegue olhar e dizer, epa! Isso me fez subir mais um degrau de uma escada, então isso deixa de se tornar dolorido- eu acho- e se torna transformador, tanto pra quem faz como pra quem assiste". Tamirys também relata um abuso sexual que sofreu.

Camila Raffanti diz que o interessante de um espetáculo com biografias é que ele acaba sendo sobre todas as pessoas, e na opinião dela é muito potente:

Sentimos medo do espetáculo se referir apenas sobre as coisinhas de cada um do elenco, mas, pelo contrário, ainda mais agora, que as pessoas estão perto fisicamente, a sensação de espelho fica mais viva. É impressionante como podemos sentir cada vez mais que estamos falando deles e não da gente, o rosto da plateia, né? (para o restante do elenco, que concorda).

A gente sente essa cumplicidade o tempo inteiro, então, nesse sentido, a experiência muda, as vezes é muito difícil, porque nós somos atravessados por algumas emoções muito fortes fazendo a peça, e nós queríamos isso, manter o pensamento, essa vibração, esse cardíaco mais aberto, não adormecido como a gente tem sentido.

Acho que está todo mundo clamando pela empatia, e quanto mais a gente fala a palavra empatia, menos parece que a possuimos, no meio da vivência, o discurso não está dando conta do que estamos precisando.

É ai que o teatro e a filosofia ganharam essa potência no trabalho, o discurso não está e nem estava dando conta, a comunicação, as notícias em geral, não estavam dando conta do que precisávamos, estávamos precisando passar pela experiência.

Os dois espetáculos analisados possuem, como se pode ver, uma preocupação muito séria e pertinente com o modo do pôr em cena; tiveram processos diferentes por conta de suas abordagens, mas, de algum modo, ambos 
estiveram conectados a um trabalho que partia do processo físico como dispositivo para a dramaturgia conjunta e suas posteriores experimentações cênicas, a partir do que já pulsavam nos corpos.

Faz-se necessário aqui tratar do tema físico, corporal, porque essa é uma possibilidade identificada que pode tornar o ato cênico potente, podendo ocasionar assim a afecção. É o que está dentro do ator que de fato o espectador se interessa em ver, e não sua mera performance marcada. O que para Baskerville também não tem um sentido atribuído, senão as marcas expostas daquilo que foi construído.

Aos leitores que desejarem visualizar parte da estética criada pelo grupo nesta peça, segue o link com o teaser da temporada do espetáculo no Teatro da Universidade da Universidade de São Paulo (TUSP). ${ }^{15}$

15 - https://www.facebook.com/espetaculoavida/videos/836542929835194/ 


\section{Afecções Possíveis - Teoria e Prática}

Muitas são as formas de afecções possíveis; além das três principais afecções paixões já vistas pelo leitor aqui, existe ainda uma infinidade de afecçõesações que podem se dar no encontro de corpos. Traçaremos aqui alguns paralelos entre as falas dos espectadores a respeito de suas experiências com os espetáculos com parte destas afecções, compondo, assim, uma possível análise.

A abordagem feita aos espectadores dos dois espetáculos sempre se iniciou em uma breve apresentação que descrevia o motivo da pesquisa e meu interesse em ter um possível relato a respeito do que eles pudessem e quisessem nomear em relação as sensações obtidas por meio das peças assistidas.

No decorrer das conversas, o método da entrevista foi sendo aprimorado, o foco foi direcionado cada vez mais para as afecções que são o real interesse deste estudo. Assim, sempre que possível, era solicitada que as falas se direcionassem mais a um sentimento particular enunciado pela pessoa, até onde fosse confortável para ela; já que, muitas vezes, os temas envolvem traumas psicológicos, como abusos sexuais sofridos na infância, conforme já citado pelas atrizes Thaís e Tamirys.

É importante registrar aqui que, por um princípio ético, ainda que autorizada pelos espectadores quase que em sua totalidade, os nomes citados nas entrevistas não são reais, para que a identidade das pessoas e suas histórias não se mantivessem atreladas. Os nomes citados a partir de agora são fictícios, mas os depoimentos seguem sem nenhuma alteração exatamente como foram narrados.

A espectadora Gabriela Martins, de $A$ Vida, foi uma das pessoas que generosamente se propôs a partilhar o impacto sentido diante do espetáculo. $\mathrm{Na}$ cena que tratava do abuso sexual contra mulher, percebeu que, tendo sido abusada na infância, nunca havia falado desta experiência, e que, de algum modo, não trazia mais isso em sua memória:

Eu me identifiquei muito com a cena da Thaís Medeiros, na peça inteira, eu me identificava com quase todas as histórias, é muito gostoso relembrar cheiros, imagens, lembranças de uma boneca, de uma avó.

Mas, de tudo o que eu gostaria de falar pra você, é que 
eu fiquei muito emocionada com a cena da Thaís, porque pra mim foi arrebatadora, apesar de ser um tema hoje muito falado, quando eu percebi que era cena de abuso eu pensei, "ah, ok, tudo bem", mas quando eu sentadinha lá, Gabriela, 36 anos, a vi falando do abuso, eu esqueci de tudo isso que hoje se fala muito, e percebi que eu nunca tinha falado disso, eu tinha vergonha, e eu fui abusada quando tinha 11 anos pelo meu tio e eu nunca contei pra minha família, eu nunca tive coragem de falar pra minha mãe, eu nunca tive coragem de falar pros meus amigos, e assim...assistindo aquela peça, nossa!

É muito dificil eu tentar explicar a minha emoção pra você em palavras, eu tive muito a sensação de voltar ao passado, me desligar totalmente daquele lugar e me ver, a minha cena do abuso, e por que eu não falei que aconteceu isso? É um trauma, e hoje eu tenho 36 anos, e nunca falei com a minha mãe, só que depois dessa cena, eu consegui me abrir com a atriz e com algumas das minhas amigas, mas eu ainda tenho vergonha de falar pra minha família, então pra mim foi meio surreal a sensação e o poder que essa cena tem de tocar várias pessoas na plateia de alguma forma, se sentir abraçada né, você não está sozinha! Isso acontece! Porque eu me achava um ogro, uma menina estranha, e infelizmente acontece muito, e a Thaís conseguiu, através dessa peça, se libertar de algumas coisas, como ela me falou, e foi legal que eu também me libertei, foi legal porque foi muito singelo, mas foi muito importante, porque a Thaís conseguiu com uma história dela dar voz a uma legião de mulheres, eu senti que a peça tem esse poder, é a Thaís, mas não ficou falando só da Thaís, ela conseguiu fazer a cena dela, me levar pro palco junto sem perder a delicadeza, ela não está encenando qualquer abuso, é uma história dela, mas eu senti que eu estava sendo abusada com ela naquele momento, agora eu chorei (pausa), e mais milhares de mulheres, me atravessou muito e eu pensei "que merda de vida"... Foi libertador, foi uma catárse pra mim, 
na verdade foi uma virada de chave, porque a gente vai vivendo muito alienado, a gente vai empurrando com a barriga, e percebe que nessas dores a gente não mexe né, e eu espero poder começar a falar disso em terapia, porque eu já faço há quatro anos e nunca tinha tocado nem em terapia, pra você ver o grau de importância pra mim, que eu nunca cheguei nem a falar pra minha própria psicanalista que eu fui abusada. Foi muito mágico, eu vi aquela cena e realmente fez desengavetar uma história da minha memória, e eu pude sentir o cheiro, a chuva que aconteceu naquele dia, eu lembrava de tudo, e foi uma loucura quando eu assisti, eu só tenho a agradecer a trabalhos como esse que transcende ser só o teatro...eu fico me perguntando por quê? Por que aconteceu? Por que eu deixei? Por que eu não falei? Porque que a gente não fala? $\mathrm{E}$ tá ai o teatro fazendo o seu papel, é um meio de comunicação pra gente gritar e denunciar. Como a gente consegue abafar os sentimentos, abafar e viver. Eu senti que eu podia estar lá fazendo a minha cena também, eu, minhas irmãs que também foram abusadas, ninguém comenta, mas uma sabe da outra, eu sai de casa achando que ia ver um espetáculo e eu vi a vida, eu vi a minha vida, foi um espetáculo que conseguiu acordar uma Gabriela de 24 anos atrás e agora bora trabalhar isso, né. E sei lá, não sei o que fazer com tudo isso ainda não, a vida tirou esse material que estava engavetado e... A vida conseguiu entrar dentro de mim, bagunçar bastante, e colocou aqui no coração pra ser trabalhado. ${ }^{16}$

O relato de Gabriela é extremamente impactante e muito coerente com a hipótese inicial dessa pesquisa, de que o espetáculo pudesse ter um papel fundamental num possível desengate de consciência, fazendo com que o espectador tivesse oportunidade de se reavaliar, e, possivelmente, a partir de então tomar novas atitudes caso desejasse. A espectadora em questão começou não apenas a se

16 - Gabriela preferiu partilhar suas afecções por meio de um aúdio via o aplicativo whats app enviado dia 03 de janeiro de 2018. 
reavaliar, partindo do princípio de que ela sofreu uma violência ainda na infância, em período de constituição, mas se viu amparada ao encontrar em uma cena que rememorou seu abuso, um despertar para a questão, que até aquele momento estava oculta no mais íntimo de seu ser.

Aqui entra uma questão muito delicada desta pesquisa, a proposição de analisar as entrevistas por meio da teoria da afecção de Spinoza até é possível, e darei seguimento a isso logo mais, mas é importante ressaltar que o que aparece nesta entrevista e nas demais é algo muito maior do que qualquer possibilidade de tradução. O teatro aborda temas que só ele pode tratar, que só a cena dá conta, nada mais, porque a cena não se dispõe a explicar, ela é a ação que nos acomete, e qualquer tentativa de fala a respeito não dá conta, Spinoza não dá conta de um tema como o estupro, nada dá conta disso, é ininteligível.

Ao sofrer uma afecção-paixão tristeza, ela reviveu as lembranças de seu abuso, se sentiu triste, como já vimos em Spinoza: "Na afecção provida de tristeza a mente passa por uma perfeição menor, referida a dor e a melancolia", (SPINOZA, 2013, p.137) ainda que melancólica e profundamente afetada, ao lembrar do que sentiu e se emocionar, Gabriela não se tornou uma serva desta afecção-paixão, como diria o filósofo caso a isso ela se encerrasse; pelo contrário, neste contato com a atriz da cena que a afetou, encontrou reflexo em seu trauma que agora poderia ser nomeado. E, junto a isso, muito mais vontade de se expressar a respeito do ocorrido, este espelho a que se referiu o grupo na entrevista voltou para Gabriela como uma sensação de paz, de que ela não estava sozinha, não era estranha, mas sim mais uma dentre as muitas vítimas que existem e que precisam encontrar um espaço para que possam dar vazão a esta sombra.

O espetáculo foi fundamental neste processo de Gabriela, pois ela mesma relata que já sabia que possivelmente, entre os assuntos acerca do tema vida, poderia haver algo relacionado ao abuso contra mulher, até mesmo por ser um tema muito debatido na atualidade. Ela se sentia tranquila quanto a isso, somente a cena a fez de fato se envolver e mudar sua perspectiva sobre o assunto foi apenas revivendo aquele momento que ela se deu conta de que o assunto que, quase cai em um esgotamento, nunca a fez falar sobre si, do que lhe aconteceu. Foi ao reviver isso em parceria com a cena, mais de duas décadas depois, que ela pôde começar a se reconhecer vítima de abuso. A partir de então, ela vai ao encontro de sua emancipação, ainda que confusa, visto o peso que a profundidade do assunto, já 
quase dado por "esquecido", poderia trazer-lhe novamente, expandindo seu crescimento na direção do que Spinoza chamaria de liberdade, a qual um sujeito sente orgulho de suas atitudes, e as toma por uma decisão que não precede de um tormento vindo de uma afecção-paixão, e sim pelo fato de a pessoa tornar-se causa adequada de suas escolhas. Rememorando ainda a entrevista da atriz Camila Raffanti, as palavras, a comunicação e os sistemas de informação muitas vezes não conseguem expressar de fato um acontecimento, e o teatro foi a forma por meio da qual o grupo encontrou para isso, e fez com que Gabriela também encontrasse uma nova espécie de eco em suas questões.

É importante ressaltar que as afecções aos corpos se dão mesmo que isso não tenha sido pretendido; o que diferencia os sujeitos são os modos com os quais eles operam diante destes encontros. Ao ter esse encontro Gabriela despertou para agir em busca de se curar, e, assim como no espetáculo, tentar deixar que isso seja registrado como mais um degrau de seu processo de vida. A atitude da espectadora remonta ainda a ideia já vista pelo leitor, de que tudo o quê existe persevera para continuar em seu ser (SPINOZA), e ela seguirá em prol de compor seus encontros com corpos que potencializarão sua potência de existir.

Residente em Vitória - Espírito Santo, a espectadora Mariana Baez, veio pela primeira vez a São Paulo, e, também pela primeira vez, assistiu a um espetáculo de teatro. Ao assistir A Vida, Mariana relata que se deu conta da importância do teatro, e como essa arte que nela suscitou maior reverberação também por meio da cena do abuso sexual, de algum modo, faz com que, igualmente, sua percepção ressoe a seus alunos na escola em sua cidade:

No sábado, quando eu fui, emocionei-me muito com várias das cenas que foram reproduzidas ali, mas as que eu mais me emocionei foram as com relação à violência sexual, porque como eu sou do interior, agora eu moro numa cidadezinha do interior, quando eu digo isso, não sei se você consegue me compreender, mas antes eu morava na roça aqui, mais distante ainda do que agora. Morávamos a minha mãe e eu, ela cuidava de um senhor, e isso é uma coisa bem particular que eu estou te contando, mas que como é uma pesquisa sua, pra você entender o quanto, o que o teatro representa na vida das 
pessoas, e eu já vivi isso, que é violência sexual, durante um tempo extenso, na verdade. Eu tinha por volta de 10, 11 anos na época, quando tudo isso começou, e eu vivenciei isso cerca de três para quatro anos, e quando eu comecei a compreender melhor as coisas, que eu me abri para uma sobrinha que era inclusive mais velha do que eu, e ela me deu alguns conselhos, me falou algumas coisas, minha mãe não sabia, a única pessoa que eu disse foi para essa sobrinha. E essa violência eu vivenciava com o patrão da minha mãe, que tinha idade pra ser meu pai, então assim, vivenciar aquilo ali, assistir aquela peça também...me emocionou muito, porque foi o que eu vivenciei, eu acredito que o teatro, na verdade eu tenho certeza disso, que o teatro é a representação da vida.

Eram duas cenas de abuso que poderiam cair e uma caiu no sábado, e outra no domingo que eu fui novamente, isso aconteceu durante aquele período de quatro anos que eu te falei, e eu tive muita dificuldade de me relacionar com os homens, eu não confiava, achava que não encontraria alguém que gostasse de mim por eu ter vivenciado aquilo... No momento que eu disse isso, que eu já tinha pelos 14 anos ninguém aceitou, até disseram com relação a gente denunciar e tal, mas era uma coisa assim, somos e éramos de família muito humilde, então a gente sentiu um certo receio, então isso pra mim foi muito difícil de me relacionar com homens, questão de confiança, de pensar se realmente a pessoa tem um interesse em mim pra se relacionar, pra ter um futuro ou apenas pra que de repente sofra um outro abuso, então essa foi a minha dificuldade maior. Eu superei com certeza, graças a Deus, mas foi difícil, não foi fácil relembrar, eu disse que eu superei, mas a gente até se equivoca nas palavras, né? Eu superei, mas isso dói, não quer dizer que não dói, me fez relembrar, me fez pensar. Nos dias de hoje, a experiência que eu vivi, me deixou mais sensível pra eu perceber isso nos alunos e nas crianças com as quais eu trabalho, eu consigo 
perceber alguns comportamentos que eu tive quando eu vivenciava aquilo, e percebo algumas crianças fazendo e percebo que passam pela mesma coisa. Como eu disse pra você, eu penso que eu superei sim, mas ter visto a peça me emocionou demais, porque mesmo que a gente supere algumas coisas, ainda dói um pouquinho, a gente sonha com algumas coisas, né? E eu não gostaria que tivesse acontecido isso, ninguém gostaria né, porque são coisas que mudam a vida da gente de alguma forma, eu sonhava com algumas coisas que na minha cabeça não aconteceram por esse motivo, mas eu tenho pra mim que a vida segue, a gente tem que de alguma maneira deixar pra trás algo de ruim que aconteceu com a gente, e tocar para frente, e pensar que a gente pode fazer diferente daqui pra frente, que a gente não deve permitir que uma coisa desse tipo aconteça com a gente. ${ }^{17}$

O relato trazido pela espectadora tem ressonância em muitas das afecções pensadas por Spinoza. Ao relatar seu despertar por meio do ato abusivo que viveu, e por meio disso conseguir dectectar movimentações não usuais entre alunos que podem vir a ser um ponto de identificação de violências sofridas, tem talvez uma grande transformação movida pela violência da qual Mariana foi afetada, calcada na ideia de liberdade do sujeito pensada por Spinoza, em relação a esse mau encontro que a espectadora viveu na infância. Ainda que a primeira afecção de Mariana seja por tristeza em rememorar o fato pessoal sofrido em seu percurso, isso, de algum modo, não a demoveu de si mesma, mas a impulsionou a superar os traumas não restaurados. Afinal, em uma afecção, seja ela positiva ou negativa, nada mais consegue se manter estável como antes, pois, segundo Amauri Ferreira, as afecções dão-se como um carimbo em um papel, existe uma marca que não se desfaz depois de afetado, mas, como disse a atriz Tamirys O'hanna "fazer disso mais um degrau desta escada" foi o que Mariana conseguiu fazer.

Ao tratar de um tema tão delicado tal qual abuso sexual, percebe-se que a

\footnotetext{
17 - Esta entrevista foi enviada via aúdio pelo aplicativo whats app dia 28 de Setembro de 2017.
} 
ressonância entre os relatos, infelizmente, cresce muito. Ainda que não seja exatamente este o foco desta pesquisa, é importante mensionar que: "normalmente não se acredita que a teoria dos afetos contribua para o esclarescimento da natureza dos impasses dos vínculos sociopolíticos" (SAFATLE, 2016, p.37). O filósofo Vladimir Safatle traz uma perspectiva interessante acerca das afecções, pois acredita que os afetos estão ligados apenas a questões individuais, e por isso não possuem dimensão do todo que pode derivar de um contexto mais amplo ligado ao comportamento humano mal orientado, derivado de uma política do medo:

No entanto, se o medo é fonte da servidão política por ser "o que origina, conserva e alimenta a superstição" da qual se serve o poder de Estado para impedir o exercício do desejo e da potência de cada um como direito natural, a esperança mostrará seus limites por perpetuar um "fantasma encarnado da imaginação impotente" aprisionada nas cadeias da espera. (SAFATLE, 2016, p.99)

Com base nas afirmações de Safatle advindas, dentre outros estudos filosóficos, dos conceitos de Spinoza aplicados na maneira de viver em sociedade, pode-se compreender que a teoria dos afetos possui uma importância singular na compreensão dos comportamentos humanos supervisionados por um conjunto político, que visa controlar e não emancipar sua pólis, proliferando com isso ações que provocam afecções de tristeza que tendem ao medo e, com isso, em certa medida, estagnação. Não foi o que se deu com as espectadoras e atrizes em questão, mas este é sem dúvida um apontamento pertinente para que se atente ao modo como os direitos básicos são cerceados sutilmente.

Ao retomar a análise das falas das duas espectadoras acerca do mesmo tema, pode-se notar que ambas relatam a ideia de não se sentirem no teatro por alguns instantes, por conta de terem sentindo como que transportadas para o momento em que viveram algo próximo a cena realizada. Isso ocorre não apenas pela afecção produzida nelas, mas também por uma atenção desperta que Carneiro divide em sua tese de doutorado, da seguinte maneira:

A atenção pode ser dividida segundo a fonte de estímulo em exógena (ou involuntária) e endógena (ou voluntária). Enquanto a primeira seria aquela que é despertada por um estímulo ambiental (um 
barulho forte, por exemplo), a segunda é fruto de uma operação interna, a mesma que realizamos quando estamos procurando alguém em meio a uma multidão. A atenção é o mecanismo que possibilita a sanidade do homem em especial na sociedade moderna, na qual a quantidade de estímulos para os sentidos é maior do que jamais se pode imaginar anteriormente. (CARNEIRO, 2016, p.37)

A tese de Carneiro tem como uma das inspirações o estudo de Hugo Münsterberg $^{18}$ (1916) baseado na obra The Photoplay, que analisa o público do cinema com base em ferramentas psicológicas de atenção e memória. Aliar esse estudo de extrema importância para conhecer e estudar a respeito das possibilidades de encontro entre o espectador e uma obra com a teoria da afecção é também uma probabilidade de ampliar por mais um ângulo o modo como podemos entender a fala de um espectador, e dar a ele cada vez mais legitimidade e importância ampliando a possibilidade de recorte nas interpretações de pesquisas.

O espectador Adriano Fers trouxe um pouco de suas impressões a respeito de Luís Antonio-Gabriela:

A história de Luis Antonio-Gabriela foi transformadora em minha vida. Sendo gay, super bem aceito pela minha família, foi impossível sair daquela história sem ter provado o saber da empatia, do se colocar no lugar do outro, e - principalmente de olhar para os próprios preconceitos.

A primeira coisa que mudou em mim foi o dedo em riste. Confesso, com tristeza, que sempre que via um travesti na rua, eu dizia ou pensava: 'olha o travesti' ou 'é uma trava, né'? Nunca mais me permiti isso!

Os monólogos do ator que representava Gabriela que a peça tinham foram dilaceradores nesse sentido. Era como se entendesse que, além da Gabriela, todas as travestis já fazem o exercício diário do se olhar no espelho, e não precisariam da minha colaboração para ser mais um para apontar suas

\footnotetext{
18 - Hugo Münsterberg 1863-1916. Sua teoria foi uma das pioneiras na história da crítica cinematográfica, ao relacionar elementos da psicologia, tais como a atenção, a memória, a imaginação e as emoções.
} 
verdades.

Assisti à peça nove vezes! Não consegui sair inerte à ela nenhuma sequer. Hoje, ao ouvir a música do Elton John, ainda choro. Tenho saudade da Gabriela, da história dela e, principalmente, do seu sentimento.

Nelson Baskerville propõe que a peça seja um pedido de desculpas dele para o/a irmão/ã. E confesso que olhar para isso na peça é - para mim - o mais difícil, porque não o acredito. Acho que é muito mais um processo de auto-piedade misturado com uma necessidade de assumir uma mea-culpa quase não o fazendo. Não o culpo, seu papel representa exatamente a sociedade da qual também faço parte. Mas não consigo enxergar como o pedido de desculpas, talvez uma retratação, mas desculpas não!

Em tempos de ideologias tão fracas, Luis Antonio-Gabriela deveria ser obrigatório, ensinado nas escassas aulas de Educação Moral e Cívica, obrigatório na literatura da Fuvest, deveria fazer parte das reflexões em família. Luis AntonioGabriela é a melhor forma de se perder um sono. ${ }^{19}$

Adriano relata que assistiu ao espetáculo nove vezes. Isso de fato aponta para uma afecção sofrida por meio desta obra teatral. É interessante perceber, em seu texto, que apenas o espetáculo, sem mais a fala reparadora de ninguém externo, fez com que ele refletisse sobre muitos pontos: seu comportamento em relação aos transexuais, seu privilégio de ter sua orientação sexual respeitada pela família, e até mesmo uma breve reflexão social a respeito de como são tratados os sujeitos que percebem outra relação com seu corpo, diante da grande massa esmagadora e preconceituosa fomentada por uma cultura que ainda não consegue respeitar os espaços para as diferenças. É importante ressaltar que o espetáculo afetou-o, a ponto de fazê-lo pensar que a peça deveria ser editada também em

\footnotetext{
19 - O espectador enviou seu relato via e-mail após o chamamento na página da rede social facebook da Cia. Mungunzá de Teatro no dia 28 de Setembro de 2017.
} 
livros, para que a temática seja abordada e repensada não apenas nos debates artísticos; que não se restringisse às discussões que, de algum modo, estão presentes nos teatros, mas, ao contrário, pudesse ser levada para lugares aonde o teatro não chega.

O ator Marcos Felipe (Cia Mungunzá) também aponta, em entrevista, que em cena é possível identificar facilmente o momento em que um espectador sofre uma afecção, e até mesmo qual é a conexão que isso possui com sua vida. Como exemplo, ele citou a espectadora Helena:

Nós fizemos uma apresentação que teve, por exemplo, a cena da carta do pai e uma trans que é a Helena, acabou naquela cena, ela começou a chorar naquela cena até o final, que existe uma carta na qual ele não pede desculpa, mas tenta justificar as ações violentas, humaniza muito a figura do pai naquele momento, e aí fica nítido né, escancara que ela tem um problema com o pai dela, e de fato ela tem, porque a gente ficou próximo, e isso ficou escancarado, então normalmente as coisas se escancaram dentro da cena, e a gente como intérprete consegue visualizar de dentro da cena, é quase que um trabalho de terapia, porque você está em cena, e viu que bateu numa pessoa de modo diferente, você entende que existe algum ruído ali, que alguma fricção naquele texto e naquele contexto que automaticamente encontrou uma fricção com a vida daquela pessoa, porque é diferente de você se emocionar gradativamente, construindo sua emoção durante o espetáculo e se emocionar no final, porque aí você se emociona com o enredo da peça, mas quando você se emociona numa cena específica é quase um trabalho de terapia que você sinaliza e diz: "opa! Tem algo ali".

Marcos faz uma análise interessante com relação a oportunidade do ator de perceber um momento de afecção específico do espectador, pois, como ele disse, é 
diferente quando a narrativa envolve um sujeito, e quando algo singular o afeta, a ação diferente do sujeito afetado o torna perceptível mediante uma plateia. Neste sentido, é coerente refletir sobre as transformações reais que um espectador pode sofrer a partir de seu contato com uma obra - neste caso teatral-, mas possível de serem estendidas as demais linguagens artísticas. Helena foi certamente afetada pela afecção-paixão tristeza, que a fez rememorar, como depois relatado ao ator, seus problemas com o pai em relação à falta de acolhimento por conta de sua identidade de gênero.

\section{1 - Marcas sob o olhar do espectador}

A Companhia Mungunzá ofereceu aos espectadores durante as temporadas de Luís Antonio-Gabriela, diversos cartazes e caixas de madeira que transportavam o cenário nas viagens, para que quem quisesse pudesse deixar parte de suas impressões a respeito da peça ao término de cada espetáculo. Segue, abaixo, parte destes escritos:

a) "O Brasil, sobretudo nestes tempos precisa ver isso. Parabéns à todos os envolvidos."

b) "É o homem frente o diferente que só aprende pela dor".

c) "Que mais Gabrielas façam a diferença na vida de outras pessoas."

d) "Maravilhoso! Terceira vez que assisti e sempre me emociono. Simplismente demais."

e) "Vou ficar regulando afeto? A vida é tão curta para se doar pela metade"

f) "A dor de todos, travestis ou não, é a dor de Gabriela. Viver dói." 
g) "Mais que um espetáculo, um poema visual e um retrato cru... e doloroso... Parabéns Nelson pela coragem. Pela entrega"

h) "Ver a vida na frente da vida. Mexer no tempo. Realmente é curta a vida e isso me dá dó".

i) "Queria eu ser como uma estrela. Queria eu morrer como uma estrela."

j) "Faço teatro há 10 anos, há dois anos andei sem motivos para continuar, Mungunzá me disse: Vem que o teatro que você quer é possível".

k) "A história de Gabriela é a minha história e a de tantos outros."

I) “A experiência de assistir esse espetáculo reascendeu em mim o sabor da infância, da dor e também da gentileza do amor."

m) "Somos o que "escolhemos", mas nem sempre podemos escolher! Um amor de peça. Beijambá".

Alguns dos relatos se deram de maneira poética, alguns com textos da própria peça que ficou na memória, outros mais diretos e questionando as trajetórias pessoais de cada espectador, mas o importante de destacar é a disposição voluntária dos espectadores para se manifestarem após a peça. Em geral, o público tende a sair do espaço cênico rapidamente ao final de cada espetáculo, e neste caso, não só permaneceu no espaço, como também envolveu seu corpo e pensamento ao dedicarem-se a ficarem inclinados ou agachados no chão, para regsitrarem suas impressões a respeito de o que assistiram.

No exame de qualificação deste trabalho, o professor Dr. Marcelo Denny contribuiu com uma reflexão muito importante, a relação de que não conseguimos saber o que nos faz não esquecer determinados espetáculos ou cenas; é como se fosse um fenômeno da natureza ao seu ver, algo sublime, "uma ficha que não cai e fica girando", e isso nos inquieta, nos diz algo, o que é? Talvez não exista uma resposta exata, apenas as possibilidades de interpretação. 
Peter Brook, em seu livro O Espaço Vazio, trata da importâcia da imagem; muitas vezes, não se pode lembrar exatamente do texto, mas uma imagem fica na memória do espectador, ele diz que: "o que a gente guarda é aquilo que não entendemos", (BROOK, 2016, p.86) ou seja, o que nos desconcerta, o que não conseguimos decodificar facilmente.

A partir da dificuldade de decodificação, a obra permanece junto ao espectador e junto dele possui vida em sua memória às vezes por anos, é o resquício que rememora a obra e faz com que o espetáculo torne-se marcante, de algum modo a ação que não se esquece retorna constantemente afim de fazer-se entender.

Carneiro complementa o raciocínio acima, contribuindo com a ideia de que talvez, mais do que uma dificuldade de decodificação, exista uma multiplicidade de interpretações. ${ }^{20}$ Este é um jogo interessante, que permite uma reflexão constante em busca do motivo de ter a ação na memória.

${ }^{20}$ Essa fala foi escrita pelo Prof. Dr. Leonel Carneiro a mão, na página 68 na dissertação impressa, lida para a participação na banca de defesa e depois entregue a mim. 


\section{Considerações Finais}

Após a abordagem dada nesta pesquisa a partir do tema ator $\mathrm{x}$ espectador com o intuito de entender parte do que é possível se dar nesta relação quanto a afecção, é preciso mencionar que as sensações de fato pouco podem ser traduzidas, elas motivam sim, muitas vezes a passos importantes na jornada de um sujeito, como se pôde ver aqui em alguns relatos, mas as relações por demais complexas que se dão, dificultam que simplesmente coisas expliquem-se por completo.

Ainda assim, é importante reconhecer o privilégio de perceber que, ao estudar fatos que ligam-se aos sujeitos em suas trajetórias de vida, existe uma riqueza em propor encontros que permitam uma troca simples, conversas sobre o cotidiano que acabam por trazer mudanças por meio da reflexão de um objeto de arte, neste caso, os espetáculos.

Muitos dos entrevistados, tornaram-se pessoas que escrevem-me para partilhar acontecimentos de sua vida pessoal desde as entrevistas, assuntos que hoje não possuem ligação com a peça assistida, pelo menos não diretamente, mas que de algum modo, viram neste encontro algo que as fazem ainda dividir algumas sensações.

Isso leva a pensar, que de fato algo foi liberado com relação às experiências de cada espectador, de modo que atualmente, as decisões são tomadas e anunciadas com clareza dos fatos e com certa alegria, talvez como a personagem Gabriela que após uma ação se revela por completo, pois não pode ser de outra forma em sua vida.

De qualquer forma não havia a pretensão de que o tema estudado esgostasse-se aqui, existe uma ampla rede de estudos possíveis a respeito do espectador, e este foi mais um prisma que pode ser importante para a conexão de áreas que não sejam exatamente a das artes, mas que agregam e dão ainda mais força ao tema se aliados a novas teorias.

A teoria da afecção de Spinoza é um caminho para olhar a cena, vislumbrar o impacto e o espanto que, muitas vezes, acometem e interpelam, mas existem coisas que só o teatro é capaz de fazer, há momentos em que é preciso suspender, parar, voltar atrás e assumir que a vida é muito mais densa nas suas relações do que se 
pode traduzir.

Acredita-se que existe uma contribuição ao campo dos estudos referentes ao espectador no sentido de aumentar o espectro de pesquisa nesta área, olhar para mais uma possibilidade de análise para a obra teatral.

É importante também ressaltar que a união da filosofia às artes cênicas é uma possibilidade não inédita, mas ainda pequena, que pode aumentar ainda mais a potência dos dois campos de estudo, levando-os para o pensar da ação cênica juntamente com a conduta prática que a filosofia pode desencadear e transformar.

O desejo é que a pesquisa possa ainda ter continuidade e possa trazer uma nova abrangência de autores que versam a respeito da cena e espectador, como por exemplo, Claire Bishop (2006) que trata do horror, do feio e do ruidoso como elementos necessários para um embate transformador.

A filosofia foi uma aliada potente ao estudo desta pesquisa, a partir de seus muitos enlaces foi importante notar como a pesquisa ganha estofo atrelada ao pensamento de uma sumidade tão interessantemente complexa em suas configurações como Spinoza.

O exercício de pensamento que pode tornar-se cada vez mais completo e denso para este campo é necessário, já que, inseridos atualmente em um contexto político no qual as condições sociais que deveriam favorecer o direito de acesso a educação e à cultura estão sendo massacradas, muitas vezes, leva-nos a crer que continuaremos distantes de ter um campo de pesquisa que nos possibilite cartografar o Brasil nesta área de concentração, que aqui ainda é precária, como em tantas outras coisas importantes no que se refere a políticas públicas. Ainda assim, sigo com o minha contribuição, desejando muito que em breve possamos ter outro cenário longe do atual fascismo que nos assombra. 
Referências

AGAMBEN, Giorgio. O que é o contemporâneo? e outros ensaios. Trad. Vinicus Nicastro Honesko. Chapecó, SC: Argos, 2009.

BASKERVILLE. Nelson. Luís Antônio- Grabriela. São Paulo. Ed. nVersos: 2012.

BISHOP, Claire. Participation. Editora MIT Press. 2006.

BROOK, Peter. O Espaço Vazio. Editora Apicuri, 2015.

CARNEIRO, Leonel Martins. A atenção e a cena. 2011. Dissertação (Mestrado em Teoria e Prática do Teatro) - Escola de Comunicações e Artes, Universidade de São Paulo, São Paulo, 2011. Disponível em: Acesso em: 09-09-2013.

CARNEIRO, Leonel Martins. A experiência do Espectador Contemporâneo: Memória, Invenção e Narrativa / Leonel Martins Carneiro. - São Paulo: L.M Carneiro, 2016. Tese (Doutorado) - Programa de Pós-Graduação em Artes Cênicas - Escola de Comunicação e Artes / Universidade de São Paulo.

DESGRANGES, Flávio. A Pedagogia do Espectador. São Paulo, Editora Hucitec, 2003.

DELEUZE, Gilles. Francis Bacon Lógica da Sensação. Equipe de tradução Roberto Machado. Rio de Janeiro: Editora Zahar, 2007.

DELEUZE, Gilles. Lógica do sentido. Trad. de Luiz Roberto Salinas Fortes. São Paulo: Perspectiva: Edusp, 1974.

FERNANDES (S. TELESI), Sílvia. Teatralidades contemporâneas. São Paulo: Perspectiva, 2010.

FERRACINI, Renato - Ensaios de Atuação. - São Paulo, Ed. Perspectiva 2013.

FÉRRAL, Josette. Encontros com Ariane Mnouchkine: Erguendo um monumento ao efêmero. Tradução de Marcelo Gomes - São Paulo: Editora SENAC São Paulo: Edições SESC SP, 2010.

FERREIRA, Amauri. Introdução à Filosofia de Spinoza. São Paulo. Ed. Quebra Nozes: 2009.

FERREIRA, Aurélio Buarque de Holanda. Miniaurélio Século XXI: $\mathbf{O}$ minidicionário da língua portuguesa. 4ed. Rio de Janeiro. Ed. Nova Fronteira, 2000.

GROTOWSKY, Jerzy. Teatro Laboratório de Jerzy Grotowski, 1959 - 1969 - São Paulo, Ed. Perspectiva: 2007. 
KOUDELA, Ingrid D. O Espanto no Teatro. São Paulo. Ed. Perspectiva: 2003. MARQUES, E. (2007). Leis Gerais, Explicações e Mecanismos: Para onde vão nossas análises? Revista Brasileira de Ciências Sociais, vol. 22, n. 64, pp. 141-145. MATE, Alexandre. Mungunzá: Obá! Produção Teatral em Zona de Fronteira... São Paulo, SP: 2018.

MORAIS, Hércules Zacharias Lima de. Como olhos de cotidiano se tornam olhos estéticos? Processos artísticos como processos de invenção de sentidos sobre o mundo. 2017. Dissertação (Mestrado - Programa de Pós-Graduação em Psicologia. Área de Concentração: Psicologia Experimental) - Instituto de Psicologia da Universidade de São Paulo, 2017.

MAUTNER, Thomas. Dicionário de Filosofia. Portugal. Edições 70 - Brasil, 2010. PELBART, Peter Pál. Elementos para uma Cartografia da Grupalidade. In: SAADI, Fátima; GARCIA, Silvana (orgs.). Próximo Ato: Questões da Teatralidade Contemporânea. São Paulo: Itaú Cultural, 2008.

RANCIÈRE, Jacques. O Espectador Emancipado. Trad. de Ivone C. Benedetti. São Paulo: Editora WMF Martins Fontes, 2012.

REYNER, Igor Reis. Pierre Schaeffer e sua Teoria da Escuta. Opus, Porto Alegre, v.17, n. 2, p. 77-106, dez, 2011.

ROLNIK, S.; GUATTARI, F. - Cartografias do Desejo - Petrópolis, Ed. Vozes: 1986. ROUBINE, Jean-Jacques. A linguagem da encenação teatral. Tradução e apresentação, Yan Michalski. 2ª edição - Rio de Janeiro: Jorge Zahar Ed. 1998.

ROUBINE, Jean-Jacques. Introdução às Grandes Teorias do Teatro. Rio de Janeiro: Jorge Zahar: 2003.

SAFATLE, Vladimir. O Circuito dos Afetos - Corpos políticos, desamparo e o fim do indivíduo. Belo Horizonte, Editora Autêntica: 2016.

SCHAEFFER, Pierre. Traité des objets musicaux: essai interdisciplines. Nouvelle Édition. Paris: Éditions du Seuil, 1966.

SPINOZA, Benedictus de - Ética - Belo Horizonte, Ed. Autêntica: 2013. 


\section{Apêndice}

\section{Relato a partir de uma entrevista com o ator Eduardo Okamoto ${ }^{21}$}

O espaço de trabalho é algo absolutamente importante; treinar diariamente foi, por muito tempo, uma prática fundamental. Obviamente, são as necessidades do trabalho que indicam quais procedimentos serão tomados. Isso pode se dar, por exemplo, não necessariamente por práticas físicas isoladas, mas também pode haver um estudo teórico e pesquisas de campos. O trabalho sobre si, de que fala Stanislavski22, ocupa este lugar em relação ao estudo pertinente para cada trabalho cênico.

"O que eu preciso pra que a comunicação em meu trabalho seja efetiva? Pode ser que seja necessário ler em voz alta e este será o treino". (informação verbal).

Eugenio Barba traz a questão do ator que, ao pisar no palco, já deve chamar para si toda a atenção e ser constantemente acompanhado nas ações restantes por toda a plateia: "Será que apenas isso é potência"? (informação verbal). Com o passar do tempo, a experiência faz com que outros caminhos sejam tomados, não só por uma apropriação do que se está fazendo, mas também pelo desejo que nasce com o trabalho. No espetáculo Agora e na hora de nossa hora, por exemplo, Okamoto não deseja que apenas sua ação seja vista, mas que, por meio desta ação as pessoas olhem para o que ele está dizendo, pra temática da peça que são os meninos em situação de rua.

A escuta é um indício que pode tornar um trabalho potente. Tudo deve ser escutado, desde as percepções que o próprio tema causa até o lugar onde se deve estrear. Deve-se pensar como aproveitar, a partir do texto ou qualquer meio utilizado na encenação, o que permite ao artista desenvolver a potência já existente no tema. Também se faz necessário escutar a potência do espectador; ela tem certa energia, e, escutando-se o espectador, certamente se obtém uma troca mais interessante.

O gesto é outro indicador que pode ajudar o ator, na medida em que ele

\footnotetext{
${ }^{21}$ - Este é um texto escrito a partir de uma entrevista com Okamoto, realizada em 2013 na UNICAMP, e permanece neste trabalho como apêndice porque foi um dispositivo fundamental, para todo 0 estudo que se deu até o momento.

22 - Constantin Stanislavsky 1863 - 1938. Foi um ator, diretor, pedagogo e escritor russo de grande destaque entre os séculos XIX e XX, e é, até hoje, extremamente importante na pesquisa teatral.
} 
souber trabalhá-lo, não apenas fisicamente, mas também na maneira de construção de seu próprio imaginário. O gesto é uma ação, e uma ação é uma mudança, na medida em que se troca um movimento por outro. O gesto é algo comandado em nossa estrutura corporal pela mente, e é necessário pensar que a mente é o que o corpo é, não adianta um ator de estatura baixa querer representar um Apolo de 1.80 de altura, isso de antemão já seria uma ideia fracassada, é importante ensinar as ideias da mente para o corpo, e aí o artista poderá de fato estar inteiro na ação.

O importante é que, a partir de um trabalho, possa-se dilatar inquietações, proporcionar um alargamento de mundo: "O ser humano é pequeno, o que está dentro é só provocação, é pra dar coragem" (informação verbal).

"Que chuvas preciso dispasmar?" lembrando do espetáculo Chuva Pasmada.

Okamoto acredita que a potência tem que fazer dilatar: "não é possível que o espectador vá para o teatro ver o que o outro faz apenas" (informação verbal). Os motivos devem ser mais do que este.

O teatro deve ser um jogo convidativo, aí está a vivacidade, não dizer como tem que ser jogado, mas convidar, permitir que, na troca de afetuosidades, torne-se esta arte, um jogo potente. 


\section{Anexos}




\section{Anexo A}

Textos das peças estudadas fornecidos pelos grupos e diretor.

\section{Luis Antonio-Gabriela}

Direção: Nelson Baskerville

Dramaturgia: Cia Mungunzá de Teatro

Intervenção Dramatúrgica: Verônica Gentilin

\section{Cena 1 / Eu nasci}

Lucas - Um nove cinco três

Eu nasci (buá) justo aqui (buá) Eu nasci e não escolhi (i)

Até fralda (buá) eu vesti (buá) Não escolhi eu nasci (i)

Quando e onde (buá) eu nasci (buá) Eu nem mesmo senti (i)

Só então (buá) entendi (buá) Eu sou travesti (i)

Anci fon fon fon

Anci fon fon fon

Anci fon fon fon fon fon fon

Anci fon fon fon

Anci fon fon fon

Anci fon fon fon fon fon fon

Quando e onde eu nasci

Eu nem mesmo senti

\section{Cena 2 / Apresentacão}

Lucas - Boa noite. Meu nome é Lucas, e eu faço dois personagens nessa peça. O primeiro se chama Paschoal, e será representado por uma careca feita de silicone e um par de meias. Eu sou pai de uma família de seis filhos. O mais velho.

Marcos - Eu sou o filho mais velho. Boa noite, meu nome é Marcos. Eu vou fazer o 
Luis Antonio que nasceu em 1953 e morreu em 2006 e ficou conhecido com o nome de Gabriela.

Sandra - Boa noite, meu nome é Sandra e eu vou fazer a Maria Cristina, a segunda filha do casal. Tem também a Mãe Gladys que será representada por um lençol branco.

Verônica - Boa noite, meu nome é Verônica e eu vou fazer o Nelson, último filho do casal Gladys e Paschoal... E diretor desse espetáculo. A minha mãe morreu no dia em que eu nasci e eu fui criado pela minha madrasta.

Virginia - Eu sou a madrasta! Boa noite, meu nome é Virgínia e eu vou fazer a Doracy, a segunda esposa do Paschoal. Sou viúva, mãe de três filhos e madrasta de mais seis.

Fábia - Oi Boa noite, eu sou a Fábia e vou o fazer o Luis Antonio, a partir do momento em que ela se muda pra Bilbao e torna-se definitivamente Gabriela.

Lucas - Meu segundo personagem se chama Serginho. Eu sou a melhor amiga da Bolota.

Marcos e Fabia - Ah esqueci, meu apelido é Bolota.

Verônica - E o meu é Bolinho

Sandra - 1953. Um dia meu pai chegou em casa com um bebê no colo e falou pra minha mãe:

Lucas - Gladys, adotei esse menino aqui!

Sandra - É assim que começa nossa peça.

\section{Cena 3 / Álbum de bebê}

Marcos - Quer uma chupeta?

Sandra - Luis Antonio nasce no dia 11 de julho de 1953, em Mogi das Cruzes, com 3 quilos e meio e 52 centímetros. Seus cabelos são castanhos e seus olhos castanhos claros.

Virginia - Nelson Baskerville nasce em Santos no dia primeiro de setembro de 1961, à 1h10, com 3,850 kg e 52 centímetros. Os seus cabelos são pretos, os seus olhos azuis.

Sandra - Luis Antonio é batizado no dia 19 de julho de 1953, em Santos.

Virginia - Nelson Antonio é batizado no dia em que nasce: primeiro de setembro de 1961. 
Sandra - O primeiro dente de Luis Antonio nasce no dia 30 de janeiro de 1954. Quem vê é mamãe Gladys.

Lucas - Eu pesco!

Virginia - O primeiro dente do Nelsinho quem viu foi o Jacyrinho, no dia 16 de maio de 1962.

Sandra - Com 6 meses Luis Antonio adora o papai do céu no crucifixo e sabe reconhecê-lo em qualquer lugar. No dia 19 de janeiro de 1954 faz pela primeira vez anci fon-fon com papai.

Lucas - Eu pesco!

Virginia - 25 de dezembro de 1961. Com quase 4 meses Nelsinho já segura a mamadeira, bate palminhas e faz anci fon fon.

Sandra - Luis Antonio dá os primeiros passos no dia 2 de agosto de 1954, com 1 ano e 1 mês.

Virginia - 7 de fevereiro de 1963. Com um ano e cinco meses, Nelsinho já fica de pé, dando os primeiros passinhos. Em 22 de maio, ele já corre muito bem!

Sandra - Luis Antonio adora quando mamãe Gladys canta para ele dormir as músicas "Lili" e a "Ave Maria".

Virginia - Com 2 anos e meio o Nelsinho arrumou uma namorada, a "Leila", uma moreninha que mora no quintal da vizinha. Ele tem loucura por ela; ele também adora cantar diversas músicas e a que mais gosta é hully gully.

Sandra - Luis Antonio gosta muito de músicas e quando as ouve dá a mãozinha para dançar.

Virginia - Aos 3 anos Nelsinho já come sozinho e está tão gordo, tão gordo, que recebeu o apelido de Bolinho.

Sandra - Luis Antonio gosta imensamente de brincar com bolas.

Virginia - Aos 4 anos Bolinho adora Moacyr Franco. Um dia, enquanto olhava mamãe rechear um peixe, Bolinho perguntou diversas vezes por que papai matara o peixe. Na hora do almoço, Bolinho não queria comer e desesperado disse: não posso comer peixe costurado!

\section{Cena 4 / Nascimento do Bolinho}

Sandra - Para o homem ancestral existiam dois céus. Um para todos os homens. $O$ outro para os guerreiros mortos em batalha e para as mães que morreram no parto. 
Verônica - Quando eu era pequeno, meu fazia eu ir com ele todo ano, no dia $1^{\circ} \mathrm{de}$ setembro no cemitério,levar flores pra uma tal de Mãe Gladys, que eu não sabia muito bem quem era, então, na minha cabeça, ela era uma santa. Aí um dia, eu tinha uns 7 anos, e eu resolvi mexer nos meus documentos. E eu encontrei a minha certidão de nascimento. E lá estava escrito que dia $1^{\circ}$ de setembro era a data do meu nascimento, e que o nome da minha mãe era Gladys. Nesse dia eu descobri que eu não era filho da minha mãe. Eu era filho de uma Santa. E que ela tinha morrido no meu parto. Nesse dia eu entendi porque meu pai nunca me contou que meu aniversário era no dia $1^{\circ}$ setembro. Porque pra ele, $1^{\circ}$ de setembro, não era comemorar o aniversário do filho.

Lucas - Era como comemorar a morte da minha mulher.

Verônica - Toda noite antes de dormir eu rezava uma oração que era assim:

Papai do céu abençoai

O papai e a mamãe

Mamãe Gladys e todos os meus irmãozinhos de casa

E fazei do Nelson Antonio um bom menino

Papai do céu abençoai

O papai e a mamãe, Mamãe Gladys e todos os meus irmãozinhos De casa

Papai do céu abençoai

Fazei do Nelson Antonio um bom menino

Fazei do Nelson Antonio sempre um bom menino

Papai do céu abençoai

Verônica - "Eu não soube nascer vírgula mãe!" (bexigas)

\section{Cena 5 / Rural}

(letreiro)

Uma perua rural Willys Estacionada na garagem Eles brigaram de novo As brigas são aos domingos Quando todos estão em casa Meu pai contra minha mãe.

- Ela não é sua mãe 
Meu pai contra a minha madrasta Os filhos dela contra os filhos dele Uma Coca "família" voa

O filho dela grita: Eu vou chamar a polícia!

Vizinhos na porta

Meu pai manda a gente fazer as malas

- Vamos embora desse inferno

Tenho medo

- Fez sua mala Nelsinho

- Fiz sim senhor Ele abre a mala Uma Lanterna

- Pra que isso?

- Pra onde a gente vai não é escuro?

(um tapa)

Meu pai entra no quarto com a minha madrasta

Eles gritam Eles choram Eles gemem

Meu pai não volta mais

(tempo)

E a gente um a um vai deixando a rural

Até o próximo domingo

\section{Cena 6 / Leite}

Sandra - Desde muito pequeno o Tonio tinha gestos, maneira de se expressar, maneira de falar de uma menina. Acho que com dois anos ele já queria minhas bonecas, maquiagem... E o jeito dele era de uma menina.

Marcos - (segura uma placa: dizem que eu nasci num corpo errado)

Virgínia - Eu conheci o Luis Antonio no início de Abril de 62 mais ou menos. Ele tinha 9 anos e tava no segundo ano do primário na classe com meu filho caçula. Eles ficaram amigos e foi por meio dessa amizade que eu conheci o pai dele, o Paschoal. Ele ia levar e buscar o Luis Antonio na minha casa, pra brincar, pra estudar, e aí a gente batia um papinho. Com o meu casório em Janeiro de 63, viemos todos morar juntos. O Luís Antonio foi quem mais gostou da nossa união. Agora o Nelsinho...oh meu Deus do céu! Como esse menino sofreu, como ele estranhou..ele chorava, ele gritava..ele chorava, tanto, tanto, tanto, que até tesoura, eu punha no berço, porque me ensinaram. Até na macumba eu levei 
ele...pra descobrir o que que ele tinha né! O Luis Antonio sofria, mas era com a morte da mãe dele. Pra falar a verdade, até hoje eu fico me perguntando e eu não entendo porque que o Paschoal casou comigo. Ele era um advogado chique, cheio de cultura, cheio de pose, viúvo, pai de 6 filhos, tinha até estudado pra ser padre! $\mathrm{E}$ eu? Eu era uma professora do interior, uma mulher simples, de família simples, eu era caipira... eu falava tudo sem o "s"... e ainda viúva e mãe de 3 filhos? Bom, mas voltando ao Luis Antonio. O Luis Antonio era um menino meigo, educado, risonho! Ele era diferente dos outros, sabe? Ele adorava enrolar docinhos e enfeitar caixas. Ah e ele fazia roupinhas pra bonecas. É verdade! Ele costurava roupinhas pra bonecas! Ahhh ele tinha uma tendência pro feminino, vai?

Sandra - O Luis Antonio foi se tornando, para nós, um problema!

Marcos - Bolinho, vamos fazer "troca troca"?

Verônica - Vamos!

Marcos - Então vem cá...

Verônica - Aí ele me levou para um vão que tinha entre o armário e a porta do quarto dos meninos. Quando a gente abria a porta, formava uma "cabaninha". (tempo)

Marcos - Vai.

Verônica - Espera.

Marcos - O que é que se tá fazendo?

Verônica - Eu não consigo. Marcos - Vou abaixar.

Marcos - Vai.

Marcos - Vai logo que pode aparecer alguém.

Verônica - pronto.

Marcos - tá gostoso? Verônica - não sei. Marcos - Então deixa eu.

Verônica - tá.

(tempo) 
Verônica - Ai.

(tempo)

Verônica - Ai.

Marcos - Fica quieto.

Verônica - ta doendo.

Marcos - Se você ficar quietinho eu vou te mostrar uma coisa.

Marcos - Bolinho, você já viu homem soltar leite?

Lucas - Você já viu homem soltar leite?

Virgínia - Você já viu homem soltar leite?

Day - Você já viu homem soltar leite?

Verônica - Então ele me levou para o banheiro, sentou na privada, tirou o pau dele pra fora e começou a balançar. Aí balançava, ele soltava uns sons esquisitos, gemia, me olhava e falava:

Marcos - Ó que gostoso, ó que gostoso, ó que gostoso...

Verônica - Aí ele começou a soltar o leite... Ele gozou. (diálogo cardigã)

Virgínia - Bolinho! Olha o que eu trouxe pra você!

Verônica - Uma blusa?

Virgínia - Um cardigã, verde, da cor dos seus olhos.

Verônica - Mas mãe! Ela era minha madrasta, mas eu chamava ela de mãe!

Virgínia - O quê?

Verônica - Olha aqui, lá no fundo do meu olho.

Virgínia - O que é que tem?

Verônica - A senhora não vê?

Virgínia - Não, o que?

Verônica - Tem um coelhinho, mãe!

Virgínia - Ah é mesmo!

Verônica - Então, a senhora precisa colocar um coelhinho na blusa.

Virginia - Tá bom!

Verônica - Boa noite, meu nome é Bolinho. "Bo" vem do verbo bordar e "linho" é diminutivo de Cu...elinho. Então Bolinho significa "Coelhinho Bordado". Eu tenho 7 anos e olhos da cor da blusa que a minha mãe me deu: verdes. Eu tenho um defeito no meu olho direito: no lugar da menina dos olhos eu tenho um coelhinho. $O$ pêlo do coelhinho cresceu tanto que entupiu meu canal lacrimal, então eu não 
consigo chorar com esse olho. Deve ser por isso que tudo que eu enxergo tem dois lados. Porque aí cada coisa vai pra um olho diferente. Eu posso escolher o que eu quero ver com cada olho. As coisas que vão pro olho do coelhinho não doem. Por causa do pêlo ó....ele não deixa.

Eu acho que foi por isso que minha mãe me deu um cardigã: pra eu lembrar de pedir um coelhinho pra enxergar macio.

Agora eu vou contar pra vocês uma história que o Bolinho viveu com o olho do coelhinho. E pra isso eu vou vestir essa máscara que não tem nada a ver com coelhinho, mas vocês vão lembrar de coelhinho quando olharem pra ela:

"Eu fui amamentado por trás. Como minha mãe não nasceu, Deus me deu um irmão que soltava leite. Mas eu não sabia que mamar doía. Deve ser porque faz tudo crescer e não sobra espaço dentro do corpo. Eu fui ficando tão cheio de leite, mas tão cheio de leite, que meu peito começou a crescer. Pra vazar todo o leite que tinha dentro, senão eu ia explodir. O leite entrou em mim e fez uma casa. $E$ agora a casa não pára de crescer. Agora eu virei isso: eu virei uma bola. Uma bola que cresce pra dar leite.

Quando a criança toma leite depois dos seis anos de idade ela pega uma doença. Uma doença que faz nascer um A no final de tudo. Mas eu não quero um A no final do meu nome. Eu quero continuar me chamando Bolinho, eu não quero ser Bolinha! Ouviu Deus??".

Depois disso nós nos mudamos, e eu me lembro que na casa nova, eu já tinha uns 12 anos de idade, e eu tinha engordado um pouco. E eu me lembro de ficar todos os dias, na frente do espelho no banheiro, olhando pro meu peito. Eu olhava e eu achava que eu estava começando a ficar com peito igual de mulher. Eu achava que porque uma travesti tinha me comido, eu podia virar uma travesti também. Como se fosse uma espécie de condenação e eu tivesse condenado a virar mulher pra sempre. Eu tinha medo de virar mulher. Eu tinha muito medo de virar mulher.

Boa noite! Agora eu vou me levantar, tirar a máscara, fechar o soro, pegar as minhas coisas, me despedir, me retirar, colocar minha camiseta do Santos e começar a próxima cena. Tchau!

Marcos - Agora eu vou parar de tocar essa música, colocar a guitarra no chão e me 
preparar para a próxima cena, tchau.

Sandra - Agora eu vou terminar de fechar meu sutiã, levar as cadeiras para a coxia e começar a preparar a próxima cena, tchau.

\section{Cena 7 / Luis XV}

Marcos - Eu Transvisto / Tu Transvestes / Ele Transveste / Nós Transvestimos / Vós Transvestis / Eles Transvestem

(conjugar verbos / tabuada)

Verônica - Estamos no ano de 1968, sob o comando do general presidente Arthur da Costa e Silva, que no dia 13 de dezembro decretou o ato institucional número 5, o famoso Al 5. Aquele lá que significou em âmbito nacional a suspensão de todos os direitos constitucionais. Na minha casa nessa época, a gente não falava em política, muito menos em tortura. Não precisava falar. A gente vivia a tortura todos os dias, dentro de casa. O meu pai era o general e nós éramos os comunistas. Eu apanho! Uns dos castigos mais criativos que meu pai aprendeu na época do seminário, ele aplicava na gente. Ele fazia a gente conjugar verbos em todos os tempos possíveis, compor redações com o tema do problema ou copiar livros inteiros. Eu tive que copiar o Guarani! Em

1969 nós nos mudamos. Saímos de uma casa na Rua Paraíba n 50, uma casa com quintal de terra, bananeiras, cadeiras de plástico e uma criação de coelhos. $E$ fomos para a Rua Euclides da Cunha, $n^{\circ} 147$.

Lucas - Eu bato.

Marcos - Eu apanho.

Lucas - Eu bato.

Marcos - Eu apanho.

Lucas - Eu bato.

Marcos - Eu apanho.

Verônica-Depois disso nosso quintal de terra se transformou em paredes brancas e limpas, nossas cadeiras de plástico viraram cadeiras de veludo e nossa criação de coelhos foi para o abatedouro.

Lucas - Seu pederasta, seu bichinha de merda! Eu te criei pra ser homem e não 
uma menininha!

Virginia - Ahhh... Eu ficava com muita pena, mas o pai do Luis Antonio fazia muita diferença com ele. Eu não sei se percebendo a sexualidade dele ou por ele não ser filho dele e ser um fruto do pecado... Mas mesmo com tudo isso, o Luis Antonio tava sempre feliz, sempre risonho, sempre de bem com a vida. Só que num dia, numa briga com o pai, ele chorava muito, porque o pai não queria ele na casa nova. E aí, eu acho, que foi nessa época que ele foi empurrado pra morar com os avós maternos. Vixii, aí foi a perdição né! Por que? Porque nessa casa moravam os dois avós que não se falavam há mais de 20 anos! Isso mesmo, 20 anos, e eu sei porque! Mas eu não vou falar..aí também tinha a tia que tinha mais 5 filhos...Agora me diz, quem que ia tomar conta desse menino? Quem ia prestar atenção nele? Quem ia tomar tento nele? Ninguém!! Foi a perdição! Ele não foi pra casa nova, o pai não queria. Fazia mal pra ele!

Sandra - O Luis Antonio foi preso algumas vezes ainda adolescente. Préadolescente ele foi preso, bateram muito nele. E a gente era obrigado a levantar de madrugada e buscar ele na delegacia, porque ele era criança ainda, né. $E$ antigamente as pessoas achavam que se corrigia a homossexualidade ou a transexualidade com surra, né... Era uma maneira de se corrigir aquilo. Era um defeito, um pensamento, uma opinião, ou qualquer coisa assim, que tinha que ser mudada. Era sem-vergonhice e tinha que ser mudada. E o Tonio apanhou muito para ser corrigido. Mas isso só piorou todo o estado dele.

Verônica - A maior surra, quem tomou na minha casa, depois do Luís Antônio, fui eu. Porque eu quebrei uma cadeira. Uma cadeira Luís XV, de veludo vermelho, horrorosa! Eu estava na sala vendo um filme bíblico que era o Maciste. O Maciste é um herói tipo esses assim que nem o Sansão. E eu era um pouquinho gordo, mas eu fingia que era forte. Aí meus irmãos começaram a tirar sarro. Eu peguei a cadeira e joguei neles! Eu arrebentei a cadeira em dois! Meu pai ficou louco. Ele não batia tanto em alguém desde a época do meu irmão. Eu me lembro de ter apanhado de soco, chute na cara, pontapé, eu me lembro de ter que cobrir o rosto porque ele me dava chute na cara e eu tinha 12 anos de idade. E ele não parava nunca. Aí eu me lembro que pra conseguir parar de apanhar, eu tive uma ideia: no meio da surra eu comecei a fingir de morto.

Lucas - Acorda Nelsinho. Levanta meu filho.

Verônica - Ele foi ficando cada vez mais desesperado e eu lá, cada vez mais morto. 
Lucas - (em desespero). Dora eu acho que matei o moleque. Eu matei o moleque! Eu matei o moleque.

Verônica - Aí eu vi que ele tava começando a acreditar então eu resolvi acordar.Lucas - Filho eu não queria ter batido desse jeito em você. O pai te ama. Não sei o que passou na minha cabeça. Você desculpa o pai?

Verônica - Não papai, eu não vou te perdoar nunca.

\section{Cena 8 / Surra de Vara I}

Marcos - Eu fui preso.

Virginia - Teve uma noite que eu escutei uma conversa do Paschoal, no telefone. Naquela época o Luís Antonio devia de ter uns 14 ou 15 anos. A conversa era com um advogado amigo dele, o amaldiçoado do Abraão. E era pra saber se tava tudo certo com a batida do investigador. Eu achei aquele papo meio estranho! Não entendi nada! E ele ó, desconversou, desviou do assunto. No dia seguinte, eu soube que o Paschoal tinha estado na delegacia de madrugada, porque a polícia tinha dado batida num lugar onde tinha orgia, drogas e bebida e todos os menores tinham sido encaminhados pra delegacia. Agora, adivinha quem é que tava no meio disso tudo?

Marcos - Eu...

Virginia - Isso mesmo! A peste do Luis Antonio!

Lucas - Nelsinho coloca a música para o papai.

Torna piccina mia, Torna dal tuo papà Egli ti aspetta sempre Con ansietà

Tra le tue braccia, amore

Egli ti stringerà

La ninnananna ancora Ti canterà

Sei tutta la mia vita Tutto tu sei per me Certo sarà finita

Se resto senza te, amore

$\mathrm{Nel}$ cielo passano le nuvole Che vanno verso il mare Sembrano fazzoletti bianchi Che salutano il nostro amore.

Marcos - O bicha, eu apanhei heim, nooossa como eu apanhei.

Sandra - "Se apanhou! Eu não conheço ninguém que apanhou mais que você, 
nunca vi".... Porque assim, as surras eram inesquecíveis. A vara era o instrumento oficial, mas o resto vinha. Era cadeira, era pau, era o que tinha, né. $E$ chegava a lesionar quase que permanentemente, porque as surras eram muito feias. Mas o Tonio , o Tonio nunca demonstrou nenhuma mágoa do meu pai.

Em 1968 ele saiu de casa, o Tonio. Ninguém se incomodou muito com a saída dele, porque já haviam muitos conflitos naquela casa, e ele era um conflito a mais, um incômodo a mais. Então pra nós, foi um conflito a menos, um problema a menos. Apesar que eu.... Eu sempre tive muita pena do Tonio. É, eu tinha pena mesmo, mas ao mesmo tempo eu também não gostava daquela situação. Então pra nós foi um alívio muito grande quando ele foi embora. Ninguém se importou. Só meu pai. Ele sim ficou bem preocupado.

\section{Cena 9 / My Melancholy Blues (traducão de Tenório)}

Another party's over

Mais uma festa se acaba

And I'm left cold sober

E eu continuo careta

My baby left me for somebody new

O meu amor me deixou por alguém novo

I don't wanna talk about it

Eu não quero falar nesse assunto

Want to forget about it

Eu quero esquecer

Wanna be intoxicated with that special brew.

\section{Quero ficar intoxicado com essa bebida especial}

So come and get me

\section{Então vem e me pega}

Let me

\section{Deixa eu}

Get in that sinking feeling

\section{Curtir esse bode}

That says my heart is on an all time low - So 
Isso quer dizer que meu coração tá sempre pra baixo - Então

Don't expect me

Não espere que eu

To behave perfectly

Me comporte bem

And wear that sunny smile

E mostre um sorriso solar

My guess is I'm in for a cloudy and overcast

Estou mais prum dia cinza e encoberto

Don't try and stop me

Não tente me impedir

'Cos I'm heading for that stormy weather soon

Porque eu estou indo em direção à tempestade

I'm causing a mild sensation

\section{Estou causando um leve incômodo}

With this new occupation

Com essa nova ocupação

I'm permanently glued

\section{Estou permanentemente grudado}

To this extraordinary mood so now move over

A essa incrivel sensação, então vá em frente

Let me take over

Me deixe curtir

With my melancholy blues

Minha triste melancholia

Sandra - Em 1968 Luis Antonio sai de casa e vai morar com os avós, Willy e Minna. Logo em seguida ele vai morar definitivamente na república de travestis chamada $A$ Casa das Bonecas, no cais de Santos. Nessa época ele já tinha injetado muito silicone industrial e também já tinha tomado muito hormônio, então já estava muito inchado. Foi nessa época que ele passou a ser chamado de Bolota.

I'm causing a mild sensation 
With this new occupation

\section{Com essa nova ocupação}

I'm in the news

\section{Eu estou na mídia}

I'm just getting used to my new exposure

\section{Estou só me acostumando com minha nova exposição}

So come into my enclosure

\section{Então entre na minha jaula}

And meet my

E conheça minha

Melancholy blues

Triste melancolia

\section{Cena 10 / Tony Star}

Virginia - Eu acho que foi com 17 anos que o Luís Antonio foi morar com o Sérgio cabeleireiro, aquele alí ó, na boca de Santos, num sobrado na Rua Bittencourt, perto do Mercado Municipal, a boca da boca, lá na prostituição...aí sim, quando o Luis Antonio foi morar com o Serginho, vixi...aí ele assumiu de vez! Ai bicha, eu não sei se eu falo...

Lucas - Fala bicha...

Virginia - Não é, é que eu tô com vergonha...é porque eu fui lá várias vezes, levar alguma comidinha ou algum docinho que ele adorava né, coitadinho! Mas também, era eu quem subia as escadas, o pai não subia não! Às vezes, o Luis Antonio descia pra cumprimentar o pai, mas o pai nem dava bola pra ele. Também, aquilo era um submundo! Ele dividia o quarto com outros rapazes. Alguns até com trajes de meninas! E tinha também a Tony Star, que era o explorador, aquele cara que ganha dinheiro em cima. Lembram, que eu falei que ele adorava costurar roupinhas de boneca? Pois então, ele continuou com esse gosto pela costura e aí ele bordava maiôs inteirinhos de lantejoulas para essa Tony Star, sabem por quanto? Por dez reais! E pasmem, a Tony Star vendia por quinhentos! Ah pelo amor de Deus! Mas isso é exploração, né? Hahaha, esse aqui 
é o Serginho! É o meu cabeleireiro! É ele que me deixa assim, linda, maravilhosa e gostosa desse jeito! Nem precisava, né bicha?

Lucas - A Bolota quando se mudou pra nossa casa não era bicha assim não. Era um viadinho, de calça jeans e camisetinha branca. A gente morava lá em sete ou oito, mas sempre tinha uns quatro ou cinco hóspedes: as bichas que vinham de São Paulo. Imagina a gaiola das loucas. Imaginou? Era a gaiola das loucas. A dona da casa era a Tony. A madre superior. Era o que a gente falava. A Tony era a Tony Fernandes, e ela era nossa diretora artística, cafetão. A gente trabalhava de graça pra ela. Se eu e a Bolota fosse fazer uma apresentação hoje lá na boate, o Renato, que era gerente, pagava pela minha apresentação para a Tony 50 reais. Pra mim ela dava 10 . E se eu fosse falar alguma coisa sabe o que ela dizia?

- Bicha, você não que aparecer? É assim. Vem cá, bixa! ( chamando a Doracy).

Vocês sabem que antigamente, pra você assumir a sua sexualidade, homossexualidade, você tinha que ser travesti.

Hoje eu não seria nenhuma travesti, não. Eu seria um viadão de bigode e teria um salão no shopping ... (fala o nome do shopping da cidade).

Lucas - A Bolota. A bolota era muito engraçada, porque assim: quando ela usava salto batia a cabeça nessa lâmpada aqui. Aí quando ela andava, andava assim: (desfila na frente do palco com tronco e ombros de lado).

Você sabe porque ela andava assim?

Por causa do ombrão.

Ela quando andava nunca parava de frente, porque de frente ficava ombrão, ela só parava de lado porque ó...

Ai bicha, se você desse um sapato, uma sandalinha pra ela servia.

Ele encolhia os dedos. Eu acho que ele calçava 50 , mas se você desse uma sandalinha 38 , servia. Ele colocava só os dedos, o pé virava canela junto. Sabe truque? É o truque de viver. É arte! Por isso que eu falo pra vocês que a gente era artista, por que a gente vivia daquela arte. A gente não tinha pagamento, não tínhamos salário, a gente não tinha, não tinha.

Marcos - Transvestir: Vestir-se com disfarce. Vestir-se principalmente com roupas do sexo oposto. Transformar a realidade. 


\section{Cena 11 / Perucas}

Marcos - Um nove sete dois.

Lucas - Aí, lá onde a gente morava tinha um tapete de felpo alto assim ó. Aí a Bolota colocou umas peruca para secar dentro de umas toucas daqueles secadores Arno antigo, de colocar no chão assim...

Aí a gente tinha feito no banheiro do fundo um camarim nosso, sabe. E a gente tava lá se maquiando e de repente veio aquela fumaceira, a casa estava pegando fogo, e a gente tudo enrolada em toalhas correndo pela Cons. Nébias. Aí chegou o corpo de bombeiros. Gente, o corpo de bombeiros foi um máximo! A gente tudo pelado no meio da rua. Eu queria que fosse hoje, agora, só pra mim poder prestar atenção.

Marcos - Um nove sete quatro

\section{Cena 12 / recorrência Surra de vara}

\section{Marcos - Dizem que eu nasci de um corpo errado}

Virginia - O Luís Antonio descobriu que era adotado tinha uns dez anos. Aí ele me perguntou, e eu disse que eu não sabia de nada, porque eu sempre soube que era filho legítimo, e que pra mim, não fazia diferença nenhuma, né? Vamos combinar? Nenhum deles era meu filho! Mas eu amava a todos igualmente. Aí, com 12 anos, o Luis Antonio foi tratar dos dentes com o meu irmão, que era dentista e que também cuidava dos dentes do Paschoal. E o meu irmão ficava buzinando na minha orelha que as arcadas dentárias do Luis Antonio e do Paschoal eram idênticas e que o Luis Antonio só podia ser filho do Paschoal! Ahhh Eureka! Foi aí que eu me lembrei de uma história que o Paschoal me contou quando a gente se conheceu. Essas coisas que se contam no começo de namoro. Ele me disse que ele sofria muito com a morte da Gladys, da mulher dele, mas que ele também tinha um remorso muito grande, porque ele tinha traído ela, quando eles moravam lá em Mogi das Cruzes, e eles, o casal, comiam de marmita numa pensão, e ele se engraçou com uma menina, filha da dona da pensão. Aí eles tiveram um caso, um romance....aí tudo isso passou, virou caso do passado e eu casei. Aí, o que é que eu fiquei pensando aqui com os meus botões? Como a Gladys não conseguia engravidar, o que é que o Paschoal fez? Ele foi lá e fez a "a caridade" de adotar o 
próprio filho. Então, na minha opinião, o Paschoal não gostava do Luis Antonio, não era por causa da questão da sexualidade dele não, porque isso "talvez" ele até perdoasse. Mas era porque o Luis Antonio não era filho dele mesmo entendeu, era um fruto do pecado. Quando o Paschoal olhava pro Luis Antonio, o que é que ele lembrava? Ele lembrava da traição!

Lucas - Nelsinho, meu filho, coloca a música para o papai.

Marcos - Querido papai, espero que seja a pessoa mais feliz do mundo, pois é meu melhor e maior amigo, espero que tenha muitos filhos e que encha essa casa de felicidade, feliz dia dos pais. De seu filho Luis Antonio.

Torna piccina mia, Torna dal tuo papà Egli ti aspetta sempre Con ansietà

Tra le tue braccia, amore

Egli ti stringer à

La ninnananna ancora

Ti canterà

Sei tutta la mia vita Tutto tu sei per me Certo sarà finita

Se resto senza te, amore

$\mathrm{Nel}$ cielo passano le nuvole

Che vanno verso il mare

Sembrano fazzoletti bianchi

Che salutano il nostro amore.

\section{Cena 13 / Morte Paschoal}

Verônica - Tonio

Marcos - Oi

Verônica - Tudo bem?

Marcos - Indo... Quanto tempo...

Verônica - É...

Marcos - Fala.

Verônica - O pai...

Marcos - $\mathrm{O}$ quê?

Verônica - Ele...

Marcos - Fala! 
Verônica - É que como o pai morreu, ele...

Marcos - Ah morreu?

Verônica - É Tonio, morreu...

Marcos - Do que?

Verônica - Enfartou. Morreu dormindo.

Marcos - Coitado

Verônica - É...

Marcos - A gente tem que ir...

Verônica - Tônio...

Marcos - é que eu não tenho o que vestir. Calça, camisa... Eu não uso mais roupa de homem.

Verônica - Tônio...

Verônica - Tonio, faz um mês.

Marcos - O que?

Verônica - Faz um mês que ele morreu, eu pensei que você tivesse sido avisado, mas que não tivesse querido ir.

Marcos - Não, não fui. Por quê?

Verônica - eu não sei. O que eu sei é que eles me pediram pra trazer isso aqui. É um documento que você precisa assinar. É pra um lance do espólio.

Verônica - Desse dia em diante o Bolinho nunca mais vai ver a Bolota.

Lucas - Querido filho Luís Antônio, senti tanta alegria ao receber a sua carta. Como gostaria que nesse dia dos Pais você também estivesse conosco. Comigo, com sua mãe e seus irmãos.

Depois que você foi embora nunca houve para mim um dia dos pais completos. Faltava você. Você é a prova de que sempre lutei para garantir a unidade da nossa família, evitando com isso acontecimentos tristes como os que foram relatados. Você foi embora porque assim quis, você escolheu o seu caminho, evitando por todos os meios que nós chegássemos até você. Com isso o tempo foi passando e você não quis mais saber de nós que somos a sua família. Você se esqueceu que foi aqui que você se criou, recebeu educação, carinho, enfim, muito amor. $\mathrm{Na}$ tarefa de educá-los, muitas vezes é claro, assim como seus irmãos, você recebeu as reprimendas que se faziam necessárias, às vezes severas, porque o meu desejo que vocês se tornassem homens de bem era 
muito grande Isso, hoje você pode julgar, é uma grande demonstração de amor.

Meu filho, sempre é tempo de se mudar de vida. Você é novo é não precisa viver uma vida de sofrimentos.

Eu estou pronto e quero ajudar você em tudo.

Seria muito bom se nós conversássemos, teríamos muita coisa para dizer um ao outro.

Escreva-me, telefone-me, e não descarte a possibilidade de nos encontrarmos.

Eu desejo muito que você seja feliz. Deus o abençoe, meu filho.

Sandra - Depois que o nosso pai morreu o Tonio sumiu. A gente ficou muito tempo sem ter notícia dele. Só uma vez que eu recebi uma ligação de um hospital de Recife dizendo que ele estava internado. Eu lembro que eu liguei no dia seguinte, mas ele já tinha ido embora. A gente ficou muito tempo sem ter notícia do Tonio, muito tempo.

Verônica - Mas a gente também nunca foi atrás pra saber.

Lucas - Depois que ela foi pra Espanha, mal se teve notícia da Bolota.

Verônica - Foram mais de 20 anos sem notícias de nenhum dos dois lados, mais de vinte anos.

Fabia - Em 1988, quatro anos após a morte do seu pai, Luis Antonio, vai para a Espanha e se torna definitivamente: Gabriela.

\section{Cena 14 / Bilbao Song}

Bill's Balhaus em Bilbao, Bilbao, Bilbao

Era o mais lindo lugar que eu já vi

Ali você fazia o que queria, o que queria, o que queria

Com um dólar você ia se esbaldar

Mas se você fosse hoje para lá, Eu não sei se você iria apreciar

Ah, pernas, risos, e um copo de brandy

E depois dançar na grama

"E a lua furando nosso zinco salpicava de estrelas nosso chão"

E a música! Ah, meu Deus, que maravilha! Eih! Joe!..., toque aquela velha canção!... Oh! lua de Bilbao! 
Oh! lua de Abril... Oh! lua de Bilbao Charutos do Brasil Oh! lua de Bilbao! Oh! lua do amor! Oh! lua de Bilbao!

Nunca me abandonou...

(Eu não consigo lembrar da letra...

Faz muito tempo...!)

Eu não sei se vocês iriam apreciar, Mas

Era tão lindo, era tão lindo

Era o mais lindo...

Que eu já vi

Bill's Balhaus em Bilbao, Bilbao, Bilbao

Hoje está modernizada e familiar

Em vez de uísque vende coca-cola - coca-cola - coca-cola

Como em qualquer lugar por aí

Mas se você fosse hoje para lá

Eu acho até que você iria apreciar

Mas para mim já não tem a menor emoção

Não tem mais grama pelo chão

Em vez de lua uma lâmpada de néon

E a música?! Ai!! Meu Deus!, que vergonha!...

Eih! Joe!, toque aquela velha canção! Oh! lua de Bilbao!

Oh! lua de Abril... Oh! lua de Bilbao Charutos do Brasil Oh! lua de Bilbao!

Oh! lua do amor! Oh! lua de Bilbao!

Nunca me abandonou...

(Eu não consigo lembrar da letra...

Faz muito tempo...!)

Eu não sei se vocês iriam apreciar, Mas era tão lindo, era tão lindo

Era o mais lindo...

Que eu já vi

Sandra - Em Bilbao tudo é muito velho, muito mofado. Tudo é escuro, tudo é preto.

Escorre água das montanhas de pedra o tempo todo. É muita água, muita água. Eu lembro que eu falava, "gente, a água do planeta está aqui!". É enxurrada dia e noite, dia e noite. Então lá tudo é muito mofado, porque tudo é muito úmido. Tudo é escuro, tudo é mofado, tudo é assim!

Virginia - Pouco tempo depois da morte do Paschoal, eu já tinha perdido o 
contato com os filhos dele. Aí eu soube que o Luis Antonio tinha se mudado pra Espanha, pouco tempo depois da morte do pai. E eu precisava conversar com ele, porque tinha uns interessados querendo comprar a mansão lá da Euclides da Cunha. Aí eu liguei pra Tony Star, aquele antigo explorador dele, pra conseguir o telefone do Luis Antonio, lá na Espanha. Liguei pra ele, lá na Espanha. Sabe o que foi que o Luís Antonio me respondeu, mais ou menos, em espanhol?

Fábia - Yo no quiero "papo" contigo. Tú estás queriendo robar a mi y a mis hermanos.

Virginia - Imagina só! Onde já se viu? Infelizmente, com dor no coração, foi a última vez que eu falei com ele... com ELA..

\section{Cena 15 / Recorrência (coreografia)}

Lucas - Décima quinta cena, recorrência da infância.

Sandra - Fora que ele tentava molestar as crianças pequenas o tempo todo, então tinha que além de tudo vigiar, porque ele tentava molestar as crianças menores, né, que eram bem menores que ele. Então, ele foi para nós, um problema!

Verônica - Porque o menino não queria virar menina. Menino que virava menina apanhava muito, era expulso da escola. Mas o peito crescia e o pinto ia ficando cada vez menor.

Sandra - O Luis Antonio foi pra nós, um problema!

( vídeo do Nelson) Mas o principal, pra contar essa história: eu não quero que tenha uma narrativa linear, nem que a cena do meio... Porque já falei isso para vocês, são três partes, por acaso são três partes. O que eu pensei é que a segunda parte, o miolo da peça, é essa viagem dela lá, agora o que está entre eu ainda não sei, eu acho que até poderia ser um drama, até podia ser super realista, sabe... Podia ser esse Ascabide aí, sabe... Podia ser esse lugar e podia ser toda essa história. Mas a primeira parte e terceira parte não, eu ainda não sei como, porque eu não queria chegar assim... Na primeira cena o pai chega com o nenê, sabe... Essas coisas todas, não queria que fosse desse jeito e para vocês irem colaborando, aí é preciso que vocês vão tendo ideias... Como é que nós vamos desenvolver isso? E a gente vai desenvolver isso com improvisação até chegar em uma estrutura, numa estrutura interessante, sabendo isso; eu tenho algumas histórias da família. 


\section{Cena 16 / Telefone sem fio}

Lucas - Em 2002, 2003... Esqueci, a bicha está com amnésia.

Bom, o que se sabe é que a Bolota na Espanha ficou rica. Ganhou dinheiro com show, parece que casou com traficante de drogas, diziam até que ela fazia turismo sexual, pegava o um pessoal do Brasil e levava para Espanha. Pegava o pessoal da Espanha e trazia pro Brasil, entendeu? Ai rolou um babado que a Bolota tinha morrido, mas não tinha morrido. Quero ver como o pessoal da peça vai contar essa história pra vocês.

Bom, eu estava no meu salão aí chegou a Biba da espanha e falou do babado com a bolota, e eu como sou amiga, quase da família da Dora peguei o telefone e liguei pra ela.

Alô, Dora, uma bicha chegou da Espanha e falou que a Bolota morreu.

Virginia - Bolinho, o amigo do Tonio ligou e falou que o Tonio morreu lá na Espanha...

Verônica - Tina, a Dora ligou e disse que o Tônio morreu.

Sandra - Em 2002 o Nelsinho me telefonou e falou que tinham ligado para ele e contado que o Tonio tinha morrido na Espanha. Aí eu falei - "Puxa, a gente vai precisar do atestado de óbito dele". Eu então mandei um e-mail para embaixada do Brasil em Madrid. Dei os dados do Luis Antonio e disse que estava procurando o atestado de óbito dele.

Day - Prezada Senhora, nós do setor consular da embaixada do Brasil na Espanha temos o prazer de informar que o senhor Luis Antonio foi encontrado vivo e reside em Bilbao, Espanha.

Sandra - Na verdade ele estava vivo e já tinham passado o meu contato para ele. Não era bem isso que eu esperava, né, porque já se havia passado muito tempo e ele já tinha se tornado um estranho que pra nós já havia causado muito transtorno, então na verdade eu falei - "Ai meu Deus, agora ele vai me procurar." E realmente aconteceu.

\section{Cena 17 / Encontro dos irmãos}


Fabia- Irmã como vai? Espero que esteja bem. La chica do consulado me mandou uma carta dizendo em que tu estavas preocupa por mim, foi uma alegria e me emocionou muito, saber que depois de tantos e tantos anos, alguém daí se recorde de mim. Até agora penso que foi uma imaginação ou um sonho que tive... Tardei em te escrever porque foi difícil acreditar que havia chegado uma carta em meus poderes.

Fico feliz que tenha uma boa família e que deus lhe deu tudo que quisesse.

Eu, meu bem, tive uma vida muito movida, viajando pra lá e pra cá, mas sempre tive sorte de tenier uma boa educação, isso serviu muito. Tive muito dinheiro, vivi muito rápido, mas sempre acreditei em um Deus, "Jesus de Nazareno" que é o protetor de las personas que viven la noite.

Hoje sou o que quis ser, mas infelizmente já tenho uma vida muito vivida, provei nessa vida de tudo, grandes espetáculos, vários vacaciones, boas peles, boas roupas... Grandes luxos.

Mas logo os anos foram passando e minha falta de cabeça hoje em dia pesa muito. Logo chegou los problemas, hospital, doença, vida mal vivida... Tive problemas nas pernas por causa do silicone. Fiquei no hospital vários dias, tive princípio de infarto... Tipos de experiências que a vida nos obriga a passar. Sempre foi uma pessoa que pensava nos demais, depois em mim.

Tenho fé de ir ao Brasil antes de morrer-mi

Sabendo que se algo acontece comigo, sei que não estou sola.

Eu não procurei vocês antes porque eu sempre tive muita vergonha de vocês, mas eu fiquei muito feliz e emocionado em saber que vocês estão me procurando.

Sandra - 20 anos depois da morte de Paschoal a irmã reencontra Luis Antonio na Espanha. Tonio? Sou eu Tonio, a Tina!

Sandra - Em 2003 o Tonio me escreveu dizendo que tinha sido assaltado e que não tinha mais nada e não tinha nem onde morar. Eu então comecei a tomar conhecimento de tudo o que estava acontecendo com ele. Nessa época eu entrei em contato com uma associação que tem lá em Bilbao, a ASKABIDE. Que é uma associação que cuida de prostitutas da terceira idade, travestis, viciados em drogas. $E$ eu também comecei a contar para os meus irmãos tudo o que estava acontecendo. Aí um dia eu falei pra um dos meus irmãos. Eu disse que eu achava que ele devia ir lá pra Espanha, pra dar um auxílio pro Tonio, pra ver, pelo 
menos, onde ele iria morar, né. Foi então que ele falou - "Olha, não é por nada não, mas eu prefiro que você vá. Eu pago toda a viagem e o que você precisar, mas eu me sentiria melhor se você fosse.". Eu estava meio desempregada mesmo, então eu falei - "Está bem, eu vou, não tem problema.". Eu fui! Eu fui pela minha mãe, porque eu sei que ela queria que eu fosse. Ela amava ele como filho né. Era o primeiro filho dela.

Fabia - Perdone-me se escrevo mal, misturo las palavras, espero que com esforço me compreendas. Irmã, besos a todos os seus. Te quiero. Muchas y muchas gracias. De sua irmã Gabriela.

Sandra -. O Tonio era um moço bem alto, de um metro e noventa, um metro e noventa e poucos. E ele tinha... ele não tinha um olho verde, mas era um castanho bem claro, diferente e ele estava sempre muito alegre, né. Então quando eu liguei lá pro pessoal da ASKABIDE eles o conheciam já. É, ele estava ficando conhecido, eu acho que até por causa da generosidade dele... ele era uma figura folclórica!... Mas enfim, do hospital ele foi direto lá pra essa associação, porque nessa época ele estava internado, então ele foi direto lá pra essa associação que cuida dessas prostitutas, travestis... Eles fazem a recuperação, a profissionalização... dessas pessoas.

\section{Cena 18 / Documentacão}

Sandra - Relato transcrito da irmã. Janeiro de 2010.

Marcos - Primeira carta de Gabriela enviada à irmã no Brasil.

Sandra - Eu, Maria Cristina, procuro meu irmão Luis Antonio que emigrou para a Espanha há mais de 10 anos e neste país teria falecido. Assim, como irmã do procurado, peço a gentileza de Vossa Senhoria de informar-me seu paradeiro se vivo ou atestado de óbito se for o caso de falecimento. São Paulo, 25 de abril de 2002.

Marcos - Maio de 2002. O Setor consular da Embaixada do Brasil em Madri informa que ainda não foi possível localizar o atual paradeiro do senhor Luis Antonio Baskerville.

Lucas - 10 de maio de 2002. Luis Antônio é encontrado vivo em Bilbao.

Verônica - Convite dos 50 anos de Gabriela. Julho de 2003. 
Virginia - Registro fotográfico da festa dos 50 anos de Gabriela. Presentes amigos e professores da Associação Askabide.

Marcos - fotografias da visita da Irmã em Bilbao.

Lucas - Carta de Moura, amigo do pai. Felicitações pelo nascimento de Luis Antonio, 6 de agosto de 1953.

Virginia - Hospital de Basurto - Bilbao/Espanha - Jan/2003 - Relatório de Internação de Gabriela por nove dias para tratamento de pneumonia, seguida de septicemia e inflamação da vesícula.

Sandra - Fotos de 1956. Luis Antonio, a irmã, Paschoal e mãe Gladys.

Verônica - "Lhe pergunto que fiz para Deus merecer tudo que está se passando comigo. Te prometo que não fiz nada". Hospital de Basurto. Gabriela.

Virginia - Jun/2003 - Com diminuição do nível de consciência Gabriela dá entrada no Hospital de Basurto. Suspeita: Consumo de cocaína. Ao final da internação por dez dias, ela já se encontra consciente, orientada no tempo e no espaço. Não recebeu tratamento anti-retroviral devido à situação hepática.

Lucas - Carteira funcional do pai. Auxiliar de fiscal de rendas, 28 de março de 1952.

Marcos - Relato digitado do Serginho, amigo de Gabriela.

Veronica - Relato transcrito da madrasta. Janeiro de 2010

Lucas - Relato transcrito de Nelson Antonio Bolinho. Janeiro de 2010.

Virginia - Álbum de bebê do Bolinho preenchido pela madrasta.

Veronica - "Minha mãe é alta e gorda e agora está fazendo regime para emagrecer". Maio de 1969. Composição feita por Bolinho sobre sua madrasta.

Marcos - Fotos da Gabriela em Bilbao com sua professora de cestaria e sua professora de espanhol.

Virginia - Bilbao, 09 de fevereiro de 2006. Cristina, te deseo lo mejor de todos los tiempos. Espero que disfrutes de um bom carnaval, pois aqui no podemos decir lo mismo. Ahora estamos na temporada de invierno. Hace mucho frio! Queria te mandar otra cosa, mas perdi los dientes no Hospital e tive um imprevisto de $600 €$. Estoy na Askabide um mês más e terei que ingresar num centro de acogida y eso me preocupa porque dicen que las monjas ponen un medicamento que hace perder las ganas de sexo. ESO ME ASSUSTA! Los quiero, Gabriela.

Marcos - Irmã como está? Espero que desfrute de um bom carnaval, infelizmente não podemos dizer o mesmo, agora estamos na temporada de inverno. Queria te mandar uma coisa, mas tive um imprevisto de 600 Euros. 
Daqui um mês terei que ir para Askabide... Dizem que as moças colocam um remédio na comida para perder vontade de fazer sexo, isso me assusta.

Sandra - Primeiro álbum feito por mãe Gladys. Álbum do Bebê de Luis Antonio.

Lucas - Foto da infância de Luis Antonio, seus irmãos e madrasta. Veronica "Retratinho da mamãe". Bolinho desenha sua madrasta.

Marcos - Segunda Carta de Gabriela à sua irmã no Brasil.

Virginia - 17 de setembro de 2003. Querida hermana, queria que conseguisse unas cosas para mi: Pomada Minâncora, Seiva de Alfazema, Bombons Garoto e Pinta unhas de colores escuros.

Sandra - Axé, Feliz 2003! Gabriela passa as festas de final de ano no hospital. Bilbao, 11 de março de 2003.

Virgínia - Dez/2004 - Cristina, te deseo todo lo mejor del mundo! Que tengas una Feliz Navidad y un Próspero Año Nuevo, lleno de paz, salud, dinero y mucho amor. Te quiero, Gabriela.

Verônica - Postais enviados à irmã no Brasil.

Lucas - Postais. 07/08/02. Ela quer voltar para o seu país.

Virginia - Peineta, acessório utilizado nos cabelos pelas espanholas, que Gabriela enviou para a irmã.

Sandra - Vestido enviado por Gabriela para a irmã passar o Carnaval no Brasil.

Marcos - Xale enviado por Gabriela à sua irmã no Brasil

Lucas - Fotos da Gabriela e a irmã na Askabide.

Verônica - Certificado de conclusão do curso de Stanislavski, concluído por Nelson Baskerville.

Virginia - Primeiro de setembro de 1962 - Certidão de Nascimento do Nelson Bolinho Baskerville.

Marcos - Certificado de conclusão do caminho de Santiago de Compostela, Nelson Baskerville.

Sandra - 1968 - Foto do primeiro dia de aula de Nelson Antonio Bolinho.

Verônica - "Meus irmãos sempre me chamam de gambá, urubu, ajax o furacão preto e muito mais apelidos. Eu sempre penso quando me chamam desses nomes que se chama é porque tem complexo". Composição feita por Bolinho sob um castigo imposto por seu pai. 1975. 
Virginia - Fotos do último show de Gabriela em Bilbao/Espanha

Marcos - Postais enviados por mim para minha irmã no Brasil.

\section{Cena 19 / Guggenheim}

Fabia - Tininha, uma vez me contaram que eu não sou filho do pai e da mãe!

Sandra - Mentira, lógico que você é filha do pai e da mãe, você é a cara da vó Catarina!

Foi até aí que eu percebi que, realmente, ela era a cara da minha vó. Foi nessa conversa, também, que eu parei pra pensar..."é, pode ser filha do meu pai, porque não?". Eu nunca tinha parado pra pensar, mas pra mim, assim, não fazia muita diferença falar, é filha do meu pai, não é filha do meu pai. E eu senti que na hora ela ficou muito confortada com a resposta, chorou muito, mas ficou muito feliz. Porque a Gabriela tinha um negócio assim, chorava, chorava, chorava, daqui a pouco já estava falando alto já estava rindo. $E$ nós começamos, então, a ter permissão pra passear. Eu ia de manhã lá pra Askabide, ela se aprontava e nós saiamos. Nos primeiros dias foi até que tudo bem. Ela tinha que usar fralda, porque a pessoa que tem hepatite $C$ no grau que ela já tinha, com comprometimento no fígado, a cirrose já instalada.... e tinha também o problema da encefalopatia, então tinha que tomar muito laxante. Tomava laxantes três vezes por dia, uma tal de Lactone, que eu não esqueci mais.

Tomou Lactone, Gabriela?

Fabia - Tomei

Sandra - Botou fralda?

Fabia - Botei

Sandra - Então hoje nós vamos para o Guggenheim ...

Sandra - Fomos para o museu, paguei as entradas, a minha e a dela... entramos no museu, chegou na segunda, terceira sala...

Que cheiro é esse Gabriela?

Fábia - Eu não pus fralda.

Sandra - Daí eu olhei, estava aquela coisa no museu: “Vamos embora, né?" E ela foi o caminho todo, nós duas andamos a pé, e ela fazendo cocô nas calças, aquele cheiro horrível. "Meu, por que não botou fralda? Sabe que precisava de fralda."

Fabia - Marca, porque marca! 
Sandra - Aí chegamos na Askabide

Fabia - Você vai me limpar, né bicha?

Sandra - Ah, mas não vou mesmo!

Fabia - Ah, então eu também não vou me limpar.

Sandra - Ah vai... Vai pro banho é agora! Tira a roupa e entra já pro banheiro!

Fabia- Você vai me dar banho?

Sandra - Eu não vou te dar banho Gabriela!

Fabia - Então eu também não vou tomar banho!

Sandra - Tá bom vai, eu seguro o chuveirinho, mas você se esfrega.

Sandra - Eu até olhei meio assim, me assustou um pouco. Eu nunca tinha visto. Era uma mulher com pênis. Ela era muito grande, morena... então tinha aquele peito enorme cheio de silicone. E cheio de pelotas de silicone pelo corpo. Porque esse silicone com o tempo ele desce, então a perna... a perna parecia de um elefante de tão inchada...

\section{Cena 20 / Gosto de dar}

Fábia - Eu tinha saudades de casa, Bilbao foi o lar que eu me dei, e era ideal para mim, mas eu sentia falta de rever minhas raízes. Rever meu pai, meus irmãos, minha mãe, o Bolinho... Não tenho arrependimentos nessa vida, tudo que eu fiz foi por amor, o mais simples dele. Não sei por que as pessoas escondem aquilo que mais querem. É gostoso dar. Eu gosto de dar. Eu gosto das pessoas. Eu olho no olho delas, onde quer que elas estejam e existe algo que me chama, como se só eu pudesse alcançar naquele momento. Seus olhos me pedem abrigo, e o abrigo que eu sei dar é esse, por que eu não tive outro tipo de abrigo. Eu aprendi a amar na rua, não casa. Na rua a gente ama sem mesquinharia, é pra todo mundo, sobra amor, sobra jeito de amar. Eu amo dando prazer e me sinto amado recebendo prazer. É bom, não é? Eu saio na rua e quero ver todos os sorrisos que eu não pude dar, e o que eu tenho pra dar, eu dou. Vou ficar regulando afeto? Regulando prazer? Me regulando pro outro? A vida é tão curta e a gente fica se dando em pedaços... Eu só consigo estar inteiro o tempo todo com quem estiver comigo, e estar inteiro é se dar inteiro. Eu cedo minha casa, minhas roupas, meu alimento, meu corpo, porque nada me pertence de fato. Está tudo aí pra ser dividido, partilhar é melhor que acumular... Eu não sei acumular afeto. Ele vaza, nas 
ruas, nos bares, nas esquinas, vazou em casa. A maneira que eu soube demonstrar o meu carinho, dentro da minha confusão, eu demonstrei. Trepar é meu carinho, é como um beijo, como um abraço, como ceder um cobertor. Porque eu vou fazer pela metade? Ceder o cobertor ao mendigo e não a companhia pra dormir? Eu não entendo. Eu sou o brinde que vai junto com o cobertor, eu sou um brinde que vem junto com a vida, pra todo mundo. Acho que todos nós somos brindes.

Virginia - Com tanta confusão, com tanta criança e eu lecionando fora, infelizmente eu não percebia se ele tava adquirindo esse lado ou se ele já tinha nascido com esse..... com esse distúrbio. Ahhh, eu não sei se essa é a palavra certa, Ahh, eu não sei explicar! A verdade é que não soubemos cuidar do menino e todos se aproveitavam dele. Viajávamos muito, só os dois, Paschoal e eu. Vivia passeando pela Europa e largava a criançada com a avó. Maior falta de juízo nossa, largava os coitados com a avó e ele, o Paschoal, sempre implicando com o Luís Antonio. Ele que era o pai né? Ele que tinha que olhar os filhos dele! Bom, eu também né? Eu também não cuidei dos meus, eu também não tive juízo. Olha, não é por falar, mas eu criava com amor, não é brincadeira, eram os 6 filhos dele mais os meus 3...Eu levava na garupa, eu ensinava lição. Passado não volta, né? Porque se voltasse eu poderia tentar ser melhor e cuidaria deles com mais amor, com mais carinho...ahh olha aqui...cuidar e controlar os filhos da gente já é complicado, que dirá cuidar e controlar os filhos dos outros!.

\section{Cena 21 / Diálogo}

Sandra - Não posso comprar apartamento aqui pra você Gabriela, eu não tenho dinheiro!

Fabia - Mas aqui eu não posso sair, eu não posso trabalhar

Sandra - Você não pode sair a noite e nem sair pra trabalhar porque você está doente, não porque está aqui. Você sabe que se você sair piora aí vai ter que voltar para o hospital.

Fabia- Então me leva para o Brasil junto com você.

Sandra - Oh Gabi, eu não posso levar você para o Brasil. Porque aonde eu vou comprar droga lá? Porque eu sei que a hora que você sair daqui, você vai voltar pro vício... e lá eu não posso sair pra comprar droga, comprar remédio. Fora que aqui 
você tem uma assistência hospital muito boa. Todo mundo aqui te ama Gabi!

Fabia - Mas não é minha família.

Sandra - Não é a sua família, mas sua família está perto. Do mesmo jeito que eu vim agora, depois eu vou voltar. Aí depois você vai lá pro Brasil me visitar. Aquelas palavras confortaram ela. O pessoal de lá falou que ela nunca tinha falado em família, então ele começou a sentir que tinha um vínculo ainda. Ela dizia - "a minha família do Brasil". E foi essa a viagem.

Verônica - Depois disso tudo eu perguntei pra Tina o quê o Luis Antônio tinha falado de mim. E ela disse que ele não se lembrava. Ele não se lembrava de nenhum Nelson.

\section{Cena / Scanneo morte}

Fabia - Querida amiga, ou melhor, irmã... Espero que Deus te encontre gozando de melhor paz. Espero que com los outros aí, esteje bem, me seria a pessoa mais feliz do mundo. Quero saber de todos, inclusive de ti. Deixei de te buscar porque não queria te colocar a par de meus problemas, irmã lhe pergunto: Que fiz pra deus... Tudo isso que está passando comigo mulher. Lhe prometo, não fiz nada. Depois e me confirmar o que tenho me pus enfermo, mas tento viver, Deus queria que fosse assim, passei mais tempo no hospital que na casa... Estou na ventana do hospital, pela manhana fiz um scanneo, estou com soro. Uma recaída que não tive cuidado. Os pés incham com o silicone. As vezes me animo e outras vezes me ponho pior, meus amigos querem que para o próximo mês me ponha um pouco melhor para poder cumprir meu aniversário. Irmã quando puder, conte me algo bonito de vocês, faça me ilusão. Saiba que enquanto estiver vida lembrarei de vocês. Espero estar oportuna para o próximo mês. Te quero. Besos. Muchas e muchas gracias de sua irmã Gabriela.

Sandra - Ela gritava muito no telefone, gritava e eu falava - "Calma Gabriela, não grita, vamos conversar!" E as enfermeiras ficavam muito bravas com ela lá, porque ela assustava os outros pacientes. Ela gritava - "Eu tô morrendo, eu vou morrer, eu vou morrer!" E eu falava - "Calma Gabriela, não grita, vamos conversar!" Aí a gente conversava e ela ia se acalmando. 
Fabia: Tininha, como era mesmo a oração que a gente fazia?

Sandra e Fabia: "Papai do céu, abençoai o papai, a mamãe, mamãe Gladys e todos os meus irmãozinhos de casa e fazei do Luis Antonio...

Fabia: E fazei da Gabriela...

Sandra e Fabia: E fazei da Gabriela uma boa menina!

Sandra: E eu sei que foi assim, uns 4, 5 dias que a gente se falou. Eu lembro que eu liguei pra ele num dia, aí no outro dia eu liguei bem cedinho, mas ele já tinha morrido. Me falaram que ele morreu no mesmo dia que a gente se falou. E eu lembro que ele perguntava na véspera - "eu vou encontrar o pai, eu vou encontrar a mãe?". E eu dizia - "não, eles já estão aí com você, estão do seu lado, estão de mãos dadas com você. Eles vão te levar pra um lugar onde você não vai mais sofrer, onde você não vai mais sentir dor. Eles vão te levar pro melhor lugar Gabi.”. Então ele só queria saber de mim se ele ia encontrar o pai e a mãe... E foi assim, daí ele acabou!

\section{Cena / Eu Morri}

Eu morri justo aqui

Eu morri e não escolhi

Desisti disso aqui

Não escolhi eu morri

Resisti até aqui

Quando então caí em si

Nunca eu existi

Nunca eu existi

Tun tun tun

Tun tun

Tun tun tun

Tun tun

Tun tun tun

Tun tun tun tun tun

Marcos e Fabia - Qué uma chupeta, São Pedro? Uma chupeta, São Marcos? Gente eu to no céu! Aqui não tem homem, não tem mulher. É alma, alma! Aqui no céu todo 
mundo é travesti!

Tun tun tun

Tun tun

Tun tun tun

Tun tun

Tun tun tun

Tun tun tun tun tun

Me fodi se fudeu

Travesti se fudeu

\section{Cena / Tributo - Your Song (Elton John)}

It's a little bit funny this feeling inside

É meio engraçado isso que eu sinto lá dentro

I'm not one of those who can easily hide

Eu não sou desses que sabe disfarçar direito

I don't have much money but boy if I did

Não tenho muita grana, mas cara se eu tivesse

I'd buy a big house where we both could live

Eu compraria uma casa bem grande onde nós dois pudéssemos viver

If I was a sculptor, but then again, no

Se eu fosse um escultor, mas também não sou

Or a man who makes potions in a travelling show

Ou um vendedor de elixir ambulante

I know it's not much but it's the best I can do

Sei que não é muito, mas isso é o melhor que eu consigo

My gift is my song and this one's for you

Meu dom é a minha música e esta é pra você

and you can tell everybody this is your song

E você pode dizer pra todo mundo que essa música é sua

It may be quite simple but now that it's done

Ela pode ser simples, mas agora que está feita

I hope you don't mind 


\section{Espero que você não se importe}

sentei no telhado e detonei o musgo

Well a few of the verses well they've got me quite cross

E alguns versos me deixaram com raiva

But the sun's been quite kind while I wrote this song

Mas o sol foi muito gentil enquanto eu escrevia esta canção

It's for people like you that keep it turned on

Ela é pra gente como você que o mantém aceso

So excuse me forgetting but these things I do

Então me desculpe por esquecer as coisas que eu faço

You see I've forgotten if they're green or they're blue

Está vendo, já esqueci se elas são verdes ou azuis

Anyway the thing is what I really mean

De qualquer jeito o que eu realmente quero dizer

Yours are the sweetest eyes I've ever seen

É que seus olhos são os mais doces que já vi

Letreiro: Esse espetáculo é um pedido de desculpas, eu to dizendo: Desculpa Tonio eu não soube lidar com isso. Nelson Bolinho Baskerville 


\section{Anexo B}

\section{A Vida}

Dramaturgia: Nelson Baskerville e Elenco

Direção Geral: Nelson Baskerville

AntiKatártiKa Teatral

(VERSÃO MIRADA)

\section{CENA 1 - CANIBAL}

Thaís - Interna Teatro Noite Santos.

Corta. Eu já vi esse filme. Já vivi esse pesadelo. Eu te sigo. Convencida pela rotina, pelos anos de convivência, pelos combinados, por tudo o que eu quis acreditar Agora eu te sigo. Depois de ser perseguida por você, eu sigo o que não mais existe.

\section{Interna Aeroporto Dia Cidade do México}

Vou ao seu encontro e apesar dos anos e de tanto vivido, nosso reencontro é raro. Somos estranhos um ao outro. Estamos num novo país. Novos códigos, novos modos, um novo você. Mesmo assim não ofereço resistência. Nem tento. Me entrego, imploro, desejo. Um amor sem vida. Contagem regressiva: 10, 9, 8 (eu não sabia) 7, 6, 5 (eu não percebi) 4, 3, 2 (eu não queria saber). Sua língua me toca, dentes nos lábios, osso na carne. Feridas. Dilaceração. Ruptura de toda estrutura.

Como chegamos até aqui? Caminho sem volta. Tudo está em seus últimos momentos, não resta dúvidas. Antes do inevitável, me agarro, luto. Lembra de quando a gente?

O mais difícil do amor... eu vivi tudo. Porque pra acabar... Você me come. Você me mastiga. Você me engole. Você me mata. Aos 28.

Interna Teatro Noite Santos

Em dezembro de 2009 fui para o México ao encontro de um canibal com quem me relacionei por cinco anos. Íamos morar junto em outro país. Ele foi na frente para ajeitar as coisas. Em nenhum momento ele disse: não venha. Eu fui. As coisas 
mudaram. Por que? Dor, loucura e sangue escorrendo pelas minhas pernas. Foi o fim.

\section{SORTEIO 1}

\section{CENA 2 - ESCONDE-ESCONDE EM SANTANA}

Uma atriz "bate cara" e atores brincam de esconde-esconde.

Camila - (em off) Rua conselheiro Pedro Luís, número 293 casa D1. Tel 2900882. O número 293 da Rua Conselheiro Pedro Luís é uma vila de 24 casas no bairro de Santana na Zona norte de São Paulo. Foi lá que eu cresci. Santana, nos anos 80, era um Bairro de classe média média com uma parte de sua população em ascensão econômica. A gente sabia que uma família estava bem de grana quando compravam um Monza. Subir na vida era ter um Monza. E pelo que os adesivos colados nos vidros dos Monzas zero KM indicavam, foi Santana quem elegeu Paulo Maluf prefeito de São Paulo. A gente brincava muito na rua nessa época. Uma das coisas que a gente mais gostava de fazer, era bisbilhotar por cima do muro do fundão da vila. O muro do fundão da vila dava para o Jardim da TFP. A nossa vila fazia fronteira com uma chácara que era sede do grupo religioso Tradição Família e propriedade. Eles faziam festas, cantavam hinos, vestiam fardas e aprendiam tiro. $E$ a gente olhava. Olhava e achava engraçado. A gente chamava eles de Os Padres. À vezes a gente jogava pedrinhas neles. Era engraçado porque eles não reagiam. Nem olhavam. Mas a gente ficava provocando. Éramos um grupo grande de crianças. Eu, Maira, Luciana, Thomás, Jesus, Paulinho, Cláudia, Carlos, Fabinho e minha irmã pequena, Laura. Na casa 06 tinha também a Patrícia. Ela era mais velha que a gente e tinha nascido com uma deficiência. Ela falava muito devagar, tinha uma perna bem mais curta que a outra e uma das mãos nunca abria. Diziam na rua que ela era assim porque o corpo da mãe dela fez ela ficar assim. O sangue da mãe atacou o feto na barriga e fez ela nascer assim. Era isso que diziam. Uma noite, fomos brincar de esconde-esconde e a Patrícia quis brincar com a gente. Eu falei pra ela se esconder bem e ficar bem quietinha, porque se ela não fosse achada, ela poderia salvar o mundo. Essa é a regra do esconde-esconde. O último a sair do esconderijo bate três vezes no pique e salva o mundo. A brincadeira acabou e os 
pais começaram a chamar as crianças pra jantar. Minha mãe me chamou e eu e a minha irmã fomos pra casa. A rua ficou vazia. Umas três horas depois, já passando das dez da noite, a campainha da minha casa tocou. Era a dona Jair, mãe da Patrícia, perguntando se a gente sabia da filha dela. A Patrícia tinha saído pra brincar e não tinha voltado pra casa. Tocamos na casa de todas as crianças pra saber se ela estava na casa de alguma e nada. Saímos todos pela rua chamando seu nome e nada. Lembrei da brincadeira de esconde-esconde e comecei a procurar por ela. Atrás dos carros, atrás das moitas.... até que eu encontrei a Patrícia. Ela estava escondida no jardim da casa da Dona Nenê, sentada, atrás do fusca azul que ficava estacionado ali. Ela estava lá há mais de três horas. Ela ficou três horas escondida em silêncio. A gente tinha esquecido a Patrícia. Eu agachei e falei, Patrícia, a brincadeira acabou faz tempo, por quê você não saiu do esconderijo? E ela respondeu: porque eu queria salvar o mundo.

A cena termina com os dançando Datemi un martello de Rita Pavone.

\section{CENA 2B - IGREJA DA POMPEIA}

Bolinho - Estou na igreja da Pompéia. Eu tenho 5 anos. A missa é chata e eu não entendo nada que o padre fala. As pessoas são altas e eu só enxergo bundas. Estou agitado e Lourdes, a empregada me manda sentar e ficar quieto. Ela está bem brava comigo. Então me sento em um dos altares laterais. Nesse altar tem um santo cravado de flechas e no chão um sino cheio de corpos. Então eu vejo uma moça. Uma moça muito bonita. Cabelos negros. Grandes. Ela usa um vestido de flores vermelhas, flores grandes e repete tudo que o padre manda com um livrinho na mão. Eu imagino que ela é minha mãe. Queria que ela aplicasse um supositório em mim. Que ela me tratasse com carinho que me deixasse ficar no colo dela o tempo que eu quisesse. Porque aqui as coisas não são assim. Porque aqui ninguém me trata com carinho. A outra mãe, a que meu pai casou de novo, me enfia o supositório com força e briga comigo porque ele volta e eu choro. Eu choro muito. Choro sempre. Choro quando me batem, choro quando gritam comigo. Eu não entendo porque todo mundo grita comigo, porque todos ficam bravos. Dizem que é porque eu sou mariquinha e não paro de chorar. Chorar não pode? Pergunto pra minha mãe de vestido vermelho com quem converso, ela não me ouve mas eu ouço a resposta dela. 
Mãe - Pode sim, Bolinho, pode chorar. Mas agora estou aqui e você não vai precisar chorar tanto. É a mamãe que tá falando.

Bolinho - E o supositório?

Mãe - Não vai precisar disso, supositório é só quando a gente tá doente.

Bolinho - eu acho que tô doente, porque estão sempre enfiando coisas em mim.

Mãe - Ninguém mais vai fazer isso.

Bolinho - Meu irmão me pegou, mamãe, eu achei que era pra tratar do meu choro, mas ele enfiou uma coisa mim.

Mãe - A mamãe vai conversar com ele.

Bolinho - Eu não sei porque choro tanto. Acho que é porque tem alguma coisa doendo mas eu não sei o que é.

Mãe - Pronto, meu amor, mamãe agora tá aqui.

Bolinho - Mãe, a senhora morreu por minha causa? Mãe - Quem falou isso? Bolinho - Eu ouvi.

Mãe - Eu não morri por sua causa, meu amor, eu vivi por sua causa.

Bolinho - Depois que ela fala isso, desaparece. Então eu pego o sino que está no chão e toco com toda minha força, todos se voltam pro meu lado. O sino é meu grito de socorro.

OU

\section{CENA 2 - MINHA SANTOS}

Nelson - (em off) Minha Santos alagava nos dias chuvas e nadávamos na rua com nossas pranchas de isopor e os ratos não mijavam, acho, e não ficávamos doentes. Na minha Santos catávamos conchas na beira da praia, abríamos com as unhas e comíamos, cada época era um bicho diferente. Tinha época de conchinha, conchona, tatuíra, estrela do mar que não era estrela. Nossas estrelas eram redondas, pareciam bolachas. Na minha rua víamos o Pelé andando em sua Mercedes azul celeste chapa mil. Na minha casa minha mãe morreu no meu parto e eu não a conheci. Quem perdeu a mãe perde-a para sempre e nunca mais para de a perder. Quem perdeu a mãe perde para sempre e nunca para de perder. Na minha casa tinha também o Tonio, meu irmão, que apanhava todos os dias porque era pederasta. 
Nelson Criança - Pederasta foi uma das primeiras palavras difíceis que aprendi.

Nelson - (em off) Meus vizinhos se juntavam na porta para saber qual era a briga do dia. Diziam que iam chamar a polícia.

Vizinha - Coitada dessas crianças.

Nelson - (em off) Nunca chamavam. Na minha casa todos apanhavam menos meu pai, na minha casa todos batiam, menos eu. Essa era a lei. Bolinho era o último a falar e o primeiro a apanhar. Tínhamos apelidos: Bolinho, Rato Branco, O Seco, o Fetza, A Estrábica, o Baiano, a Louca. Fomos tratados de forma sádica, por isso aprendemos a ser sádicos. Éramos todos sádicos lá em Santos. Essa é minha Santos de nascimento e aqueles eram os anos 1970. Esse é o Ricardinho, um garoto com síndrome de down, que vivia solto na rua, nem sabíamos onde morava. Chamávamos de "mongol". Sentado nesse chão, encostado no muro, o dono da casa vai jogar um balde de água com soda cáustica de limpeza sobre ele porque não queria um mongol sentado na sombra de seu muro. Essa que vai passar agora é a Elaine que usa um colete ortopédico, ela vai passar por mim, eu rio dela e jogo um nome na sua cara:

Nelson Criança - Aleijada!

Nelson - (em off) Jogávamos nomes. Por que não? Eu mesmo tinha "pé chato" e usava as botas ortopédicas do Doutor Scholl e me chamavam de "Pé de Pato". Aprendi uma piada nova com meus irmãos mais velhos, muito engraçada. Uma garota negra passa por mim e digo:

Nelson Criança - Abriram a porta do jardim zoológico.

Menina negra - E você é um leão!

Nelson - (em off) Essa frase vai me perseguir a vida inteira. Uma moça fez topless no canal 1 em 1978.

Nelson Criança - Puta.

Nelson - (em off) A mãe do Paulinho, que morava de frente pra nossa casa, era desquitada, chamávamos de "Vaca", porque mulher desquitada era vaca.

Nelson Criança - Vaca.

Nelson - (em off) E o Paulinho era o Paulinho da Vaca. Os professores também podiam bater na gente. Dona Ruth me puxava orelha, Dona Maria José me chamava de Cruz, o professor Musa me deu um chute para eu aprender a sentar direito e o professor Simeoni, de violão, me chamou de débil mental. Eu não sei tocar violão. Pederasta Bolinho Rato Branco O Seco o Fetza A Estrábica o Baiano a louca 
mongol aleijada macaca

leão vaca cruz débil mental Pederasta Bolinho Rato Branco O Seco o Fetza A Estrábica o Baiano mongol aleijada macaca leão vaca cruz débil mental A cena termina com os dançando Datemi un martello de Rita Pavone.

\section{CENA 2B - VARIZES DE ESÔFAGO}

Felipe - 11:30 da manhã. O restaurante onde eu trabalhava ia abrir ao meio dia. Toca o meu telefone: - Pai / Eu tô vomitando sangue / Consegue ir sozinho para o hospital? / Acho que sim / Te encontro lá! Falo pra chefia que não vou poder trabalhar naquele dia. E corro para o hospital. Entro no PS a tempo de ouvir o plantonista perguntar para o meu pai: - Sr Fernando? O Sr Bebe? / Bebia. Docini. Faz o meu pai. 11:30 da manhã. O restaurante onde eu trabalhava ia abrir ao meio dia.Toca o meu telefone: - Pai

Docini - Eu tô vomitando sangue

Felipe - Consegue ir sozinho para o hospital?

Docini - Acho que sim

Felipe - Te encontro lá! Thamirys. Faz a chefia / Meu pai tá vomitando sangue Thamirys - Fê. Corre pro hospital.

Felipe - Entro no PS a tempo de ouvir o plantonista perguntar para o meu pai: - Sr Fernando? O Sr bebe?

Docini - Bebo.

Felipe - Bebia. Hércules. Faz o plantonista. 11:30 da manhã. O restaurante onde eu trabalhava ia abrir ao meio dia. Toca o meu telefone: - Pai

Docini - Eu tô vomitando sangue

Felipe - Consegue ir sozinho para o hospital?

Docini - Acho que sim

Felipe - Te encontro lá! Thais. Faz a chefia / Meu pai tá vomitando sangue Thaís- Fê. Corre pro hospital.

Felipe - Entro no PS a tempo de ouvir o plantonista perguntar para o meu pai:

Hércules - Sr Fernando? O Sr Bebe?

Docini - Não. Eu como com farinha. 
Hércules - Comia

Felipe - Pai

Docini - Eu tô vomitando sangue

Felipe - Consegue ir sozinho para o hospital?

Docini - Acho que sim

Felipe - Te encontro lá! Meu pai tá vomitando sangue

Tamirys, Thaís e Camila - Fê. Corre pro hospital.

Felipe - Entro no PS a tempo de ouvir o plantonista perguntar para o meu pai:

Hércules - Sr Fernando? O Sr Bebe?

Docini - Se eu parar eu quebro uma destilaria na Escócia.

Hércules - Então vai quebrar. Leva pra UTI.

Felipe - Enquanto houver gelo haverá esperança. Eu não sou um acoolatra anônimo, sou um bêbado conhecido. Ainda morro disso. O dia que tiver que parar, eu paro. Só bebo socialmente, mas minha vida social é intensa. Esses foram bordões que cresci ouvindo. Nosso apartamento tinha um bar de madeira feito sob medida. Nas prateleiras uma grande coleção de garrafas de whisky em miniatura que ele adquiria na ponte aérea Rio - São Paulo. A coleção de mexedores de coquetéis enchiam diversos copos. No console do nosso carro, um diplomata, ele carregava uma enorme quantidade de cartões de clube do whisky, eram muitos cartões. Isso fazia com que em sempre houvesse uma garrafa a sua espera. Em diversos pontos da cidade. Todos os dias uma, duas, três doses. Foi assim durante mais de 30 anos. Um dia chegou o diagnóstico. Varizes de esôfago em decorrência de cirrose hepática alcoólica. Ou para de beber, ou para de beber. Ele parou. E então uma lenta e potente mudança na nossa relação teve início.

\section{CORRENDO PELA VIDA - SEM LEGENDA SORTEIO 2}

\section{CENA 3 - MINHA MÃE É SEPARADA}

Thaís - Minha mãe é separada. Minha mãe trabalha fora. Minha mãe é atraente. Os homens do prédio desejam a minha mãe. Minha mãe usa sapatos de salto. Os homens do trabalho desejam a minha mãe. Minha mãe tem horário de almoço e alguns dias almoça no shopping. Os homens do shopping desejam a minha mãe. 
Por algum motivo minha mãe se constrange por ser separada. Ela faz de tudo para provar que apesar de separada continua sendo uma pessoa responsável.

Camila - Em Cingapura o dia amanheceu nublado com previsão de fortes pancadas de chuva pela tarde.

Thaís - Minha mãe é separada. Sou proibida de ir na casa da Lucy. A Lucy ficou puta porque minha mãe se separou. Quer dizer, a Lucy acha que minha mãe é puta porque se separou. A Lucy não quer ver nem eu nem e minha mãe. A Lucy fica louca só de imaginar que minha mãe pode encontrar o marido dela no elevador. Durante um bom tempo eu ainda insisti em convidar as filhas da Lucy para brincar. Toda vez que eu ligava e alguma delas atendia o telefone e percebia que era eu elas ficavam mudas do outro lado da linha. Quando a Lucy atendia e eu perguntava porque as meninas não podem brincar ela simplesmente respondia: porque não.

Camila - Em Bangladesh uma forte tempestade deixou diversos pontos alagados. Equipes de resgate estão em alerta.

Thaís - Minha mãe é separada. Minha mãe trabalha fora então ela não pode fazer que nem as outras mães que moram no prédio e são donas de casa que ficam a tarde no térreo trocando receitas de suflê. Essas mães donas de casa dizem que eu fui vítima de uma escolha infeliz por parte dos adultos. Os filhos dessas mães donas de casa me perguntam como eu reagiria frente a um juiz caso tivesse que escolher entre a minha mãe e o meu pai. Eu ainda não sei disso mas aos 14 anos, esses mesmos filhos dessas mães donas de casa vão aproveitar do fato que a minha mãe separada está fora de casa trabalhando e irão tocar insistentemente a campainha da minha casa tentando aproveitar do fato de eu estar sozinha para me violar.

Camila - Em Kathmandu um deslizamento de terra deixou centenas de desabrigados. Equipes de resgate buscam sobreviventes.

Thaís - Em 1989 uma forte chuva de granizo alagou diversos pontos da cidade de São Paulo e impediu que uma mãe separada e sua filha cruzassem uma grande avenida.

Camila - E apesar de todo o transtorno.

Thaís - Apesar do vidro quebrado

Camila - E do carro alagado.

Thaís - E da chuva de granizo e da mãe separada e da filha que não estava entendendo nada. Apesar de tudo. Deu tudo certo e hoje estou aqui fazendo esta cena. 


\section{OU}

\section{CENA 3 - SUPERMERCADO}

Atores estão em um supermercado.

Thaís - Camila foi casada por oito anos com aquele sujeito. Aquele com aquela roupa maravilhosa de papai noel e que está empurrando o carrinho de compras mais lotado da história dos carrinhos de compras lotados. Dos oito anos em que estiveram casados, dois Camila gastou pensando se deveria se separar dele ou não. Eles eram muito amigos e ela gostava muito dele. Por isso achava que não deveria se separar. Mas por esse mesmo motivo, porque eles eram muito amigos e ela gostava muito dele, ela se separou dele no final de 2013. Dois anos depois, no dia 31 de dezembro de 2015, Camila encontrou seu ex- marido no supermercado.

Camila - Oi. Coincidência te encontrar.

Camila se aproxima do ex-marido e ele praticamente a ignora.

Camila - Como você tá? Sua mãe tá bem? Seu irmão?

Ex-marido finge "demência". Eles se despedem e Camila se afasta. Camila para, pensa e vai até a narradora.

Thaís - Camila para. Pensa. E decide assumir a cena.

Camila - Boa noite, senhora e senhores, eu queria um minutinho da atenção de vocês por favor. Você pode tirar o som por favor? Obrigada. Eu não vou tomar muito o tempo de vocês. Prometo. Eu sei que é véspera de ano novo, tá todo mundo querendo ir pra casa ver se o pernil já assou. Mas é rapidinho. Vocês estão vendo aquele sujeito ali? Então. ele acabou de fingir que não me conhece. Mas não é verdade. A gente não só se conhece, como fomos casados por oito anos. Eu conheço ele. Juro. E eu posso provar. Quer ver? Eu conheço ele tão bem, tão bem que eu sei por exemplo, que ele nunca faz xixi em pé, só sentado. Verdade ou mentira? Conheço ele tão bem que eu sei que ele nunca lê um livro inteiro, apesar de ter uma casa cheia de livros. Conheço ele tão bem que eu sei que ele se recusa a morar em casas que não tenha bidê. Porque ele se recusa a usar papel higiênico na região anal. Verdade ou mentira? Conheço ele tão bem que eu sei que o filme favorito dele é Peixe Grande. Do Tim Burton. Ele chora como uma criança vendo este filme, sabem por quê? Porque esse filme fala de um homem que justifica as 
canalhices do pai, retratando ele como um sonhador. Sua mãe dizia que você é igual seu pai. Olha onde eu fui me meter. Eu conheço ele tão bem, que eu sei que ele tem uma espinha na barriga que nunca cicatriza. Pode olhar. Você aí. Pode olhar.

Felipe - É verdade. Tem até aquele pontinho amarelo.

Camila - Eu conheço ele. A gente passava todos os verões na praia. Foram oito verões. Ele adora tomar sol mas detesta passar protetor solar. Eu que passava. $\mathrm{E}$ como ele é grande eu praticamente engraxava um fusca todos os dias antes de ir pra praia. Mas pode parecer estranho só lembrar de coisas embaraçosas e humilhantes a seu respeito, mas a verdade é que eu lembro muitas coisas boas a seu respeito. Muitas. Mas tem um problema. A pessoa que eu conheci e que eu amei, nunca teria feito o que você fez aqui hoje. A pessoa que eu conheci, nunca teria sido tão mesquino, tão mentiroso. E principalmente, a pessoa que eu conheci jamais teria feito minha filha sofrer. Então, eu estou diante de um dilema. Ou pessoa que eu conheci era uma mentira, ou você agora é uma mentira. E eu não posso lembrar com carinho de um passado que talvez não tenha acontecido de verdade. Você roubou meu passado. Mas quero te dizer que tudo bem. Você pode ficar com o passado pra você e fazer com ele o que você quiser. Ou melhor, o que você puder. Feliz ano novo, estranho.

Thaís - A cena termina de forma inusitada.

\section{Elenco dança a coreografia ao som de "Marcas do que Se Foi". UM LUGAR NA VIDA (GRACIAS A LA VIDA)- SEM LEGENDA SORTEIO 3}

\section{CENA 4 - O PORCO}

Imagens de arquivo são projetadas.

Camila - Esta era a minha casa.

Rua Euclides da Cunha, número 147, aqui em Santos.

Foi construída pelo meu pai. Ele adorava reunir a família. Adorava juntar todo mundo no natal.

Acho que o Natal era a única época em que era possível extrai alguma felicidade 
daquele conglomerado.

Eu devia ter vindo visitar ele aqui naquele domingo de manhã. Não vim.

Naquela mesma noite meu pai dormiu e não acordou mais.

O primeiro natal sem meu pai foi complicado.

Decidimos fazer uma coisa totalmente diferente dos natais que tínhamos em casa.

Nada de tristezas.

Mataríamos um porco para assá-lo com uma maçã na boca.

Para matar um porco você precisa:

1) Dar uma marretada na cabeça.

e:

2) Enfiar uma adaga bem no coração do bicho.

Nós seguramos o porco e de repente... pum!

Uma marretada na cabeça.

Depois enfiamos a lâmina bem no coração e pronto. Estava acabado.

Pelo menos era isso isso que pensávamos.

Quando soltamos o porco, ele começou a gritar e saiu correndo esguichando sangue para tudo quanto era lado.

Ele correia e esguichava sangue. E a gente corria atrás.

Éramos quatro marmanjos atrás de um porco de quarenta centímetros.

À noite o porco estava na mesa com uma maçã na boca.

É... ninguém comeu. Meu pai não estava lá.

\section{Atores nus correm atrás do porco.}

\section{OU}

\section{CENA 4 - BONECAS PRETAS}

O palco está vazio. Tamirys entra carregada como uma boneca.

Entra a música Bonecas Pretas. Tamirys "ganha vida" e começa a dançar e dublar a música.

Um caso contestável

Direito questionável

Necessidade de ocupar 
Invadir as vitrines, lojas principais

Referências acessíveis é poder pra imaginar

Mídias virtuais

Anúncios constantes

Revistas, jornais

Trocam estética opressora

Por identificação transformadora

Procuram-se bonecas pretas

Procura-se representação!

No fim, atores entram e trocam sua roupa. Ela entoa, a capela, o hino "Campeão", da igreja que ela e sua família frequentavam.

Acredite é hora de vencer

essa força vem de dentro de você

você pode até tocar o céu se crer

Acredite que nenhum de nós

já nasceu com jeito pra super herói

nossos sonhos a gente é quem constrói

é vencendo os limites escalando as fortaleza

conquistando o impossivel pela fé

Campeão vencedor Deus da asas faz teu voô

Campeão vencedor essa fé que te faz imbativel

te mostra o teu valor...

\section{SORTEIO 4}

\section{CENA 5 - MULHER VULCÃO}

Thais - Hércules! Hércules! Hércules!

Hércules - Eu não sei se eu vou conseguir falar.

Thais - Te ajudo 
Hércules - Obrigado. É difícil colocar em palavras...

Thais - Mas precisa. Você entendeu, né? A imagem é forte, mas fica solta...

Hércules - Eu não sei se eu vou conseguir... parece que se... as palavras não vão dar conta... se eu falar vai diminuir, falar...

Thais - Não se preocupa, não vamos perder o mistério. É disso que se trata também, né?

Hércules - É!

Thais - Quando você se sentir confiante, você assume a cena sozinho, tá?

Hércules - Tá.

Thais - Legal. Começamos juntos. Quem é ela?

Hércules - A mulher vulcão

Thais - E o que transborda desse vulcão?

Hércules - Eu. Eu sou feito dessa lava.

Thais - Quem são estes com estas malas?

Hércules - Ela e a vida dela. Andou por toda parte. E agora se prepara pra sua ultima viagem.

Thais - Ela está pra morrer?

Hércules - Todos nós não estamos?

Thais - Mas do que se trata essa cena?

Hércules - Sobre ser agraciado pela proteção de alguém. Sobre receber como herança todos os lugares por onde passou, o que viu, aprendeu. Eu não tinha condições de pedir e ela simplesmente fez.

Thais - Talvez fosse inevitável. O que aconteceu?

Hércules - Eu não consigo falar.

Thais - Tudo bem. Ela parou de andar durante a sua gestação.

Hércules - Ela realmente não escolheu. Ela foi lá e deu a vez para mim.

Hércules assume a cena

Mãe - Filho, agora é a sua vez.

Hércules - Mãe, levanta.

Mãe - Daqui a pouquinho, amor. 
Hércules - Eu fiz isso com você? Eu não queria te machucar.

Mãe - Fazia parte do combinado. Está tudo certo. O sangue continua correndo silencioso aqui por baixo. Logo mais transborda, e aí você sabe, né?

Hércules - Eu sei que nunca nada que eu fizer vai ser o bastante.

Mãe - Não se preocupe. Eu nasci para dar a vida a você. Fazia parte do combinado. Eu simplesmente sabia. E assim foi.

Hércules - Mãe, eu já te disse que te amo?

Mãe - Ainda meu filho?

Hércules - E sempre minha mãe.

Mãe - Filho! A mãe tá um pouco cansada. Estou querendo ir embora. Você me leva pra dançar? E tem que ser bonito.

\section{OU}

\section{CENA 5 - LA NONNA E MORTA}

Camila limpa e veste sua avó morta.

Camila - Eu convivi muito com as minhas duas avós. Quando a mãe da minha mãe morreu eu mesma fiz a maquiagem no rosto dela. Ela sempre pedia pra ser enterrada bonita. Então foi minha homenagem Quando minha Nonna morreu, eu não pude ir ao enterro porque a minha filha era muito pequena e o enterro foi no interior. Eu queria muito ter me despedido dela. Eu queria muito ter falado algumas coisas para ela. Então eu vou me despedir agora. A minha nonna viveu as duas guerras. Ela sempre contava que quando era pequena nunca teve uma boneca. $A$ única boneca que ela teve, ela mesma fez de barro. Por isso, depois de velha, aqui no Brasil, ela colecionava bonecas. Tinha o quarto cheio de bonecas. Quando a gente se enjoava de alguma, ela não deixava a gente jogar fora. Ela reformava roupa, penteava o cabelo e guardava.

Camila canta uma canção em italiano.

CORRENDO PELA VIDA, COM NELSON BASKERVILLE 
1949 - Meus pais se casaram

1961 - Eu nasci

1961 - minha mãe morreu no meu parto

1962 - eu morava com meus avós

1968 - meu primeiro dia na escola

1970 - o Brasil foi tri campeão da copa do mundo

1978 - subi num palco pela primeira vez

1979 - dispensa militar por insuficiência física temporária

1984 - meu pai morreu quando eu tinha 22 anos

1985 - fiz "Uma Lição Longe demais" de Zeno Wilde com Fauzi Arap, um novo pai

no teatro

1986 - Nasceu Julia, minha filha.

1988 - me mudei para Londres e decidi nunca mais fazer teatro

1990 - eu era magro

1994 - participei do topa tudo por dinheiro com Silvio Santos

1995 - tirei uma foto com Maradona, Maradona estava bêbado

2002 - Minha mãe nos palcos, Miriam Mehler, obrigado.

2005 - a Antikatártika Teatral se reúne pela primeira vez

2012 - homenagem dos 100 anos do Santos Futebol Clube

2012 - atravessei a Patagonia de moto.

2016 - melhor não comentar.

\section{CENA 6 - PISCINA}

Locução em off:

Aí, tudo que vai fazer. Quem é? Quem ta aí? Ah, é o filho do zelador. E aquele que ta ali? É o filho do zelador. Quer dizer, sempre o zelador é uma pessoa que tá morando num prédio e ele tem, tem... limite. Ele tem que saber aonde ele pode entrar, até aonde os filhos dele pode ir, aonde ele pode participar. O zelador tem que saber de tudo isso. O que aconteceu num dia aí, a vinte e oito anos atrás. Arrumei um trabalho, fui trabalhar, comecei trabalhando num prédio, depois de dois meses que eu tava trabalhando no prédio, eu mudei pro condomínio. Aí a Maria do Carmo, ela não era nem síndica, era esposa do síndico. Ela ligou pra mim e perguntou: "Sr 
Zacarias, o Sr tem filho?" Eu falei tenho. "Quantos?” Três. Hummmm. Ela já falou assim Hummmmm. Eu falei pra ela: Dona Maria do Carmo, eu não entendi. "Não. É que tem piscina." O que ela quis falar com piscina? Porque os filhos do zelador iam querer participar, tomar banho de piscina junto com os filhos dos condôminos, ia querer usar a piscina, usar salão de festas, uma quadra, tudo isso aí. Quer dizer, eu me senti naquela hora que ela falou, ela não falou em todas as letras, mas ela falou isso aí. Porque ela fez hummm? Hummmm. Por que, Dona Maria do Carmo? Piscina. Eu falei: A senhora pode ficar sossegada, porque os meus filhos nasceram em condomínio, embaixo de um prédio, eu sendo zelador, mas meus filhos sabem aonde eles põem o pé, onde eles devem colocar o pé, e aonde eles não devem. Meus filhos já desde nascidos, já foi educado. Sim, não. Não, sim. Eles sabem onde que realmente dá. A senhora pode ficar despreocupada que a senhora nunca vai ter esse privilégio de reclamar dos meus filhos. Isso foi o que eu respondi para a Maria do Carmo. Até que no passar do tempo, vocês pequenos, o Emerson estudando, o Hermes estudando, você era o mais pequeno, e a Maria do Carmo veio procurar por mim: "Sr Zacarias, cadê teus filhos?"Eu falei: Meus filhos trabalham durante o dia e à noite eles vão para escola. "É que faz tanto tempo que eu não vejo os seus filhos." Aí eu peguei e falei pra ela: A senhora lembra do que a senhora quis falar pra mim, quando eu comecei a trabalhar no condomínio? E a senhora quis falar pra mim? Sobre piscina com os meus filhos? Lembra que eu falei pra senhora que a senhora podia ficar tranqüila. Tranquila que meus filhos nunca iriam dá um problema no prédio. Qualquer desfeita meus filhos não iam causar. Por quê? Eles nasceram num condomínio. Saberiam muito bem onde poder participar e saberiam onde não. É tanto que nessas alturas, você lembra que a Dona Márcia do décimo, 101, chamou você pra brincar na piscina, e ela perguntava se eu deixava. Eu lembro que uma vez você foi teimoso e você foi, mas eu não deixava você não ir. Por quê? Inclusive eu falei pra ela. Dona Márcia a senhora não fique chateada comigo não, porque não é que eu proíbo. A senhora quer o meu filho junto com o seu, pode descer, brincar, é que se eles vão pra piscina, mas é que têm os outros no condomínio, tão vendo que o meu filho, como filho do zelador tá tomando banho na piscina dos condôminos, então a senhora me desculpe, é por isso que eu não quero que eles participem.

\section{SORTEIO 5}




\section{CENA 7 - ABUSO NA PRAIA}

Thaís dorme. Hércules chega em Thaís. Coloca a mão dentro do vestido, na buceta dela. Ela entre sonho e realidade, desperta, mas volta a dormir.

Thaís - Nojo. Quando eu lembro eu sinto nojo. Era verão. Eu tinha uns 18 anos. Eu estava num apartamento familiar. Com pessoas familiares. Um lugar em que nada deveria acontecer. Todos dormiam. Em uma noite uma mão dentro da minha calcinha se misturou com o meu sonho. Eu tomei um susto. Ele também. Eu não consegui mais dormir. Ele também. Depois de um tempo depois ele voltou. Não sei se ele fez isso porque pensava que eu dormia, então não lembraria ou se ele sabia que eu estava acordada então deduziu que eu consenti. De fato, eu passei mais de 15 anos sem lembrar dessa história. Falei sobre isso pela primeira vez durante o processo de criação deste espetáculo

$1,2,3,4,5 \ldots$

Enquanto Thaís conta as agressões os três gozam na cara dela.

\section{OU}

\section{CENA 7 - ISSO É AMOR}

Tamirys - o Felipe vai lavar as mãos agora. E o Docini vai ajudar ele com isso.

Um ator traz uma bacia com álcool gel. Felipe lava as mãos. Outro ator traz uma toalha. Enquanto acontece Tamirys fala.

Tamirys - Isso poderia ter sido a reprodução de um filme de romance, algo consentido, um ato de amor. Não foi! (para Felipe) O Felipe vai enfiar dois dedos em mim ! Depois vai me beijar, depois vai me dar um tapa na cara. Isso foi combinado.

Camila - Em algum lugar uma garota abriu a porta de sua casa para o que ela pensava ser o amor de sua vida, seu príncipe encantado, devaneios de menina por acreditar cegamente no amor da Disney, onde felizes para sempre e a única opção. Ele chegou de bicicleta, bermuda descolada, camisa em $\mathrm{V}$ e chinelos! Entrou como se a casa fosse sua, limpou os pês no tapete da porta. Entrou. Deu meia volta como se tivesse esquecido algo.

Hércules - "E melhor tirar o chinelo né?" 
Camila - Ela o mirava admirada, nem ouviu direito o que ele havia dito, apenas consentiu. Ele pegou suas mãos com delicadeza. Ela sorriu. Ele fechou a porta.

Hércules - "Onde fica o quarto?".

Camila - "Lá em cima". Ele a levou pela mão fazendo pequenos círculos em sua palma. Ela não parava de sorrir. Ele rapidamente olhou o quarto

Hércules - "Senta ali naquela poltrona".

Camila - Ela sentou e sorriu.

Hércules - "Tira a calca".

Camila - Ela não entendeu. Ele tirou pra ela. Ela não se mexeu. Ele a beijou. Ela não sabia o que fazer. Ele enfiou dois dedos nela.

Tamirys - "Ta doendo".

Camila - Ele a beijava.

Tamirys - "Ta doendo".

Felipe - "Não chora não, isso é amor."

Tamirys - Escrevi tudo isso pra te lembrar que isso aconteceu! Talvez você tenha esquecido. Eu não. Você rapidamente seguiu sua vida. Eu não. Você já tem outra namorada. Demorei muitos anos pra entender o que tinha acontecido. Entendi. E é por isso que te escrevo essa carta, para dizer que te perdoo. Perdoo sua crueldade, perdoo sua frieza. te perdoar me liberta! Tira as amarras que me mantinham presa a você. Não quero mais ser lembrada como sua vitima. Te perdoar me da coragem! Meu perdão não te absolve da SUA CULPA, mas me faz lembrar que a CULPA NUNCA FOI MINHA. Carta enviada para Rua Maria Graziela, Cubatão.

\section{CENA 8 - PIROCAS}

Tamirys canta no karaokê: uma versão feminista de "Moço", sucesso de Wando.

Moço, me espere amanhã

Levo o teu coração

Pra poder me vingar

Moço,

Moço eu te prometo

Eu te viro do avesso, 
Só pra te castigar

Moço, eu não vou sentir pena

Quando estiver te fudendo

Eu vou até gostar

Moço, todo meu sofrimento

É na mesma moeda

Que você vai pagar

Eu quero te rasgar o corpo inteiro

Te enrabar com um pau sem sebo,

Te deixar vivo,

Só pra te empalar

Eu quero, eu quero...

Eu quero achar graça disso tudo

E com os velhos amigos

Me vangloriar,

Te de capar

Moço, vou tirar teus direitos,

Vou te deixar com medo

De pelas ruas andar

Moço, vou agarrar teus cabelos

Te chamar de gostoso

Tua bunda apertar

Quero te humilhar no teu emprego

E dizer que vai perde-lo

Se você não me chupar, me faz gozar

Agora agora

Eu quero te bater de todo jeito

Deixar roxo o seu rosto inteiro,

E te matar,

Se você falar

Eu quero, eu quero... 
Eu quero te xingar de vagabundo

Cuspir nessa tua cara,

Se não me obedecer,

Eu quero, eu quero...

\section{CENA 9 - MACISTE E JULIA}

Thais - O menino não tinha dúvida que era sua casa que se movia. Deitado no chão fresco do quintal da casa de Santos, um mosaico de cimento cru e vermelho, áspero, o menino ficava olhando para o céu. Tudo se movia em alta velocidade formando figuras de bichos, gente e coisas. Ele ficava com as mãos, braços e todo o corpo bem grudados no chão, com medo de que algum movimento mais brusco o tirasse daquela casa. Depois de um tempo ele corria para a porta da rua pra ver se a casa tinha saído do lugar. Mas não. A casa permanecia ali e ele percebeu muito cedo que as coisas não seriam tão fáceis assim. O menino não conheceu a mãe porque ela morreu no seu parto.

Camila - Quem perde a mãe perde-a para sempre e nunca para de a perder. Quem perde a mãe perde para sempre e nunca para de perder.

Thais - Esse é o Maciste. Um herói criado pelo cinema italiano. Foi o primeiro herói do menino. Domingo. O menino tem 11 anos e assiste Maciste na televisão. Ele tira a camisa e com seu corpo gordinho imita o herói. Todos se irritam com ele. Por quê? Os irmãos o pegam e dão uns petelecos. Xingam. Gordinho super herói. O enchem de apelidos: Bolinho. Barril de banha. Baleia. Maria da Breca, uma referencia à inspetora de alunos megera da escola. O Maciste de 11 anos pega a primeira coisa que suas mãos alcançam e joga contra os agressores. O Maciste pode. $O$ gordinho não. Ele arrebenta uma cadeira Luiz XV, estilo colonial. Valor atual no mercado: $R \$$ 750,00 . Suspensão. O tempo pára uma eternidade.

Felipe - O pai vem em sua direção. Um búfalo enraivecido. O menino tentou correr. Estava de meias num chão de mármore. Com as duas mãos o pai pega uma pequena quantidade de cabelos logo acima das orelhas. Levanta o menino e o lança no chão. Levanta o menino e o lança no chão. Levanta o menino e o lança no chão. Repete o movimento 3 vezes. No encontro com o chão pela terceira vez, chuta as costas, chuta a bunda, chuta as coxas, chuta as costas de novo. 
Thais - Para pai! Para! Onde é que está o ar?

Felipe - Fecha a mão e acerta o peito. Acerta o braço. A família assiste ao show passiva. Tapas desajeitados tentando atingir o rosto. De cada dois pega um. Volta ao pequeno chumaço de cabelo na lateral da orelha. Levanta o menino pra descobrir o rosto e dessa vez acerta todos os tapas.

Thais - Pára pai. Pára pai. Alguém podia pelo menos tirar minhas meias pra eu poder correr?

Felipe - Agora o búfalo pega um orelha e desfere mais tapas. Fecha a mão.

Thais - Esse filho da puta vái me matar.

Felipe - O menino finge desmar, ainda sim leva mais alguns golpes. Como não tem mais reação pára a surra. Tummmmmmmm.

Thais - Agora velho, o menino não briga. Velho, ele tem medo de apanhar. Cresceu com medo. Cresceu com a certeza que qualquer um pode destruí-lo. Ele agora aniquila pessoas. Mata. Mata amigos. Mata colegas de trabalho. Os parentes ele matou faz tempo. Bastam duas frases discordantes e ele rompe. Rompeu todos os casamentos. Quase aniquilou uma filha. Desculpa filha e obrigada por não desistir de $\operatorname{mim}$. Aniquila porque toda tentativa de individuação foi aniquilada.

Nelson (off) - Maciste não tem tradução. Me remete a Maciço. Único. Peça única. Porque eu sempre me senti quebrado. Aos pedaços. Eu estava tentando ser maciço. Meu Maciste foi humilhado. Aniquilado.

Thais - Mamãe, você morreu por minha causa?

Camila - Eu não morri, vivi por você.

Thais - Naquele domingo o pai não bateu no menino que quebrou uma cadeira. Naquele domingo o pai espancou o menino que matou a mãe.

Camila - Quando nasce um filho uma arma é apontada pra sua cabeça. Uma vez que ele existe, a ideia de que ele deixe de existir é aterrorizante. Uma ameaça constante. É o desespero que grita: sobrevive! Sobrevive! Sobrevive! Aos vinte e um anos, sozinha com você nos meus braços olho no fundo dos seus olhos e te amo. Não sei quem você é mas te conheço. Não sei como criar alguém, mas olho nos teus olhos e meu coração, que bateu junto com o seu por nove meses, se enche de coragem e eu digo: Oi, filha, meu bebe, meu amor. Vem comigo, tá? Eu não sei muito bem pra onde estou indo, mas vem comigo, vou te ensinar tudo o que puder, tudo o que eu souber. Vou te dar tudo o que tiver. $\mathrm{E}$ o que não tiver vou criar. A gente 
vai aprender junto. Você vai me ensinar também. E um dia você vai andar sem mim.

\section{A GRANDE BELEZA}

E tudo termina com a morte. Mas antes, tem o espaço antes da morte. Um espaço. A vida. Escondida debaixo de um grande blá blá blá. Cidades e civilizações construídas por cima de conversas e barulhos. Camadas de concreto. Silêncios e sofrimentos. Blá blá blá. No meio de alguns poucos vislumbres de beleza. E nossa infelicidade sórdida e nossa miséria e desumanidade. Tudo enterrado debaixo da máscara da vergonha, para disfarçar o medo e a emoção, o pavor de estarmos vivos. Blá blá blá. E depois de tudo tem o além. Mas o além não é um lugar para se preocupar. Então vamos começar esse espetáculo. Depois que as cortinas se fecharem. Afinal é tudo um truque. A vida é só um truque.

Camila vai até a roleta e a gira. Luz vai caindo enquanto a roleta não para de girar. 